\title{
A Comparison of Martin Luther King and Malcolm X in the Black and Mainstream Press, 1955-2011
}

\author{
Daniel Cruden
}

A thesis submitted to Victoria University of Wellington in fulfilment of the requirements for the degree of Master of Arts in History

Victoria University of Wellington 



\begin{abstract}
$\underline{\text { Abstract }}$
Most historians of the black protest movement claim that the mainstream media misrepresented Martin Luther King and Malcolm X as opposing figures, without detailing how the media achieved this, how these representations influenced King and Malcolm X's posthumous media images, or how African-American media representations of the pair differed from mainstream representations. In order to understand how this misrepresentation came to be, and what its implications were for memory of the two after their deaths, this thesis examines the representation of King and Malcolm $\mathrm{X}$ in mainstream and African-American newspapers from the beginnings of their public careers until 2011.
\end{abstract}

Newspapers drew on their pre-existing views of American race relations to evaluate the importance of King and Malcolm X. During their lifetimes newspapers selectively conveyed the ideologies of both men, embracing King's leadership while distrusting Malcolm X. After their deaths, newspapers sanctified King and discussed him extensively, often confining his significance to the battle against legal segregation in the South. Newspapers gave Malcolm X less attention at first, but rehabilitated him later, beginning with African-American newspapers. The failure of the black protest movement to end racial disparities in standards of living, combined with King's appropriation by the mainstream media, paved the way for much greater attention to Malcolm X by the late 1980s. By this time, newspapers represented King and Malcolm $\mathrm{X}$ as politically compatible, but continued to give them distinct personas that still affect public images of African-American leaders, such as Barack Obama, to this day. 


\section{Table of Contents}

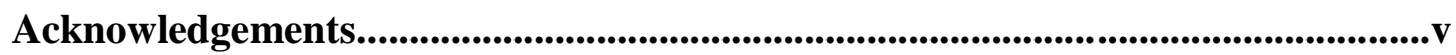

List of Abbreviations.............................................................................................................................vi

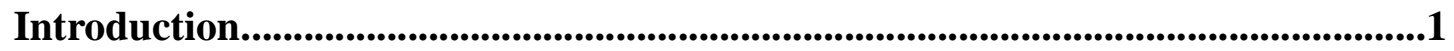

Chapter One: "Two Ways".....................................................................................15

Chapter Two: Mourning to Memory ..............................................................37

Chapter Three: Converging Politics; Contrasting Personalities............................57

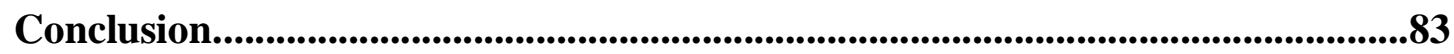

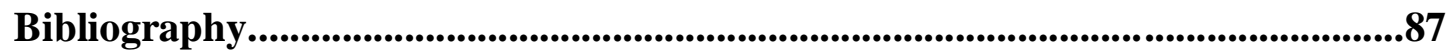

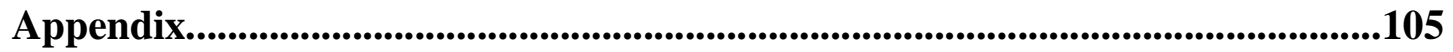




\section{$\underline{\text { Acknowledgements }}$}

My interest in this topic was sparked by an Honours course in American history taken by Dr. Peter Field at the University of Canterbury. I will always appreciate Peter's enthusiasm, and his support in my decision to pursue this topic further. I would also like to thank Peter's colleague Dr. Stephen Hardman for his advice in the early stages of formulating this topic, and for his feedback on earlier drafts.

My parents, John Cruden and Sue Mitchell, provided an inexhaustible source of support in many forms: money, proofreading, baking, and unqualified sympathy being the first that spring to mind. I hope that fifteen months of unquestioningly supporting a son in postgraduate study does not become another fifteen unquestioningly supporting a son who cannot decide what to do with the resultant degree.

The VUW History postgraduate community proved a supportive scholarly environment, and it has been a pleasure to study beside every single one of its members. I am particularly indebted to Simon Judkins, Grace Millar, Florence Baggett, and Matthew Vink for their help and feedback in the last stages. I was lucky to have Dr. Steve Behrendt as an interim supervisor for the final two weeks, as his advice proved very helpful in getting through the final stretch.

Finally, and most importantly, I am extremely grateful to my supervisor, Dolores Janiewski, for her advice, support, constructive criticism, and her extensive knowledge on this topic - and many other topics as well. Dolores was meticulous in her feedback, insightful in her advice, and always exceedingly generous with her time. If she considers the time she spent on me a wise investment, I will consider this thesis a triumph. 


\section{List of abbreviations}

AC Atlanta Constitution

$A D W$ Atlanta Daily World

$B W$ Birmingham World

$C D$ Chicago Defender

LAPD. .Los Angeles Police Department $L A S$ Los Angeles Sentinel LAT. .Los Angeles Times NAACP ..National Association for the Advancement of Colored People NYAN. New York Amsterdam News $N Y T$ New York Times

PBS ..Public Broadcasting Service $W P$ Washington Post 


\section{Introduction}

In early 2008, American presidential candidate Barack Obama - the first African American with a significant chance of winning the presidency - nearly had his chance of winning the Democratic Party's nomination derailed by his former pastor Jeremiah Wright. In video footage aired by all major television outlets and quoted in major print media, Wright, angry at the persistence of American racism, urged his congregation to sing "God damn America". Wright also quoted Malcolm X, and claimed that the September 11 attacks were a case of "chickens coming home to roost". ${ }^{1}$ For someone seeking to become America's first black president, an association with Wright was undesirable, and the controversy presented Obama with a dilemma. He obviously could not say anything that would imply he shared Wright's beliefs, but given pre-existing fears on the part of some African Americans that he was not "black enough" to keep their support, nor could Obama deny his race.

Obama responded to the Wright controversy in a speech that sought to explain black anger without defending it, and to situate himself as heir to a civil rights movement that brought both black and white Americans together. ${ }^{2}$ As Wright represented an angry response to white supremacy, reminiscent of Malcolm X, Obama responded by associating himself with the conciliatory side, represented by Martin Luther King, Jr. As the most recognisable leader of the black protest movement from the 1950s and 1960s, King provided a safer image than the radical one offered by Malcolm X. By channelling King and the civil rights movement, Obama turned his racial identity, which had provided an obstacle, into an advantage.

This thesis examines the challenges facing African Americans who aspire to national leadership by investigating mainstream and black newspaper representations of King and Malcolm X from the late 1950s to 2011. It traces the role of these newspapers in

\footnotetext{
${ }^{1}$ Roland Martin, 'The full story behind Rev. Jeremiah Wright's 9/11 sermon', CNN, 21 March 2008, http://ac360.blogs.cnn.com/2008/03/21/the-full-story-behind-rev-jeremiahwrights-911-sermon/, accessed 3/6/13; Martin, The full story behind Wright's "God Damn America" sermon, CNN, 21 March 2008, http://ac360.blogs.cnn.com/2008/03/21/the-fullstory-behind-wright $\%$ E2\%80\%99s-\%E2\% $80 \% 9$ Cgod-damn-america\%E2\%80\%9D-sermon/, accessed 3/6/13.

${ }^{2}$ Barack Obama, ‘A More Perfect Union', 18 March 2008, American Rhetoric, http://www.americanrhetoric.com/speeches/barackobamaperfectunion.htm, accessed 13/6/13.
} 
representing King and Malcolm $\mathrm{X}$ as opposing figures. It sheds light on how the media imbued the two with distinct personas after their deaths, even as historians increasingly depicted the two as fundamentally similar. It shows that newspapers endorsed King's leadership during his lifetime, at the expense of Malcolm X's, largely due to King's careful adherence to nonviolence. Comparing the mainstream press with black newspapers, the thesis shows how African-American media viewed both King and Malcolm X as important figures for African Americans, even while the mainstream press neglected or rejected Malcolm X. It then outlines the transformation of King into an icon of national significance after his assassination, and the much slower process by which Malcolm X was turned into a black icon by the late 1980s.

King and Malcolm X were born in the 1920s, a time of widespread de jure racial segregation in the South and de facto segregation in the rest of the country. Living standards for African Americans had not improved significantly since the 1860s. Although the two men had vastly different experiences growing up, they both emerged as visible leaders in a black protest movement that gained greater prominence with the Supreme Court's 1954 decision in Brown v. Board of Education, which declared racially segregated schools to be unconstitutional. Both King and Malcolm X eventually shared an unfortunate fate, as they were both assassinated in the 1960s.

Malcolm X was born in Nebraska in 1925 as Malcolm Little into a dysfunctional family with an abusive father, before the family moved to Wisconsin and then Michigan. The Little family was broken up before Malcolm X reached adulthood. When Malcolm X was a small boy, his father was found dead by a rail track, apparently murdered by white supremacists for his political activism. Subsequently, his mother was committed to an insane asylum and the Little children ended up in foster care. After moving to Boston and then New York as an adolescent, Malcolm X engaged in petty crime before being imprisoned as a young adult. In prison, he converted to the Nation of Islam, a separatist organisation that claimed white people were devils. Upon his release, he began preaching for the Nation in the early 1950s 
before rejecting the Nation's racial ideology and splitting with the organisation in 1964, before being assassinated on 21 February 1965 in New York City. ${ }^{3}$

King was born into a stable middle-class Atlanta family four years after Malcolm X, and had a relatively comfortable childhood. Despite living in the South, he grew up in a relatively comfortable environment and was spared the worst of Southern racism. King studied at both black and mixed-race universities before becoming a minister at Dexter Avenue Baptist Church in Montgomery, Alabama. Not long after taking this job, King became famous for leading the Montgomery Bus Boycott in 1955. From there, he became nationally associated with the battle against segregation. He remained the most well known figurehead of the black protest movement until his assassination by a white supremacist in Memphis on 4 April 1968. ${ }^{4}$

Newspapers in the United States have represented King and Malcolm X as opposing, mutually exclusive figures, both during and after their lives. This misrepresentation stemmed from a misunderstanding of the ideologies of both men. Mainstream newspapers, contrary to their black counterparts, ascribed King's importance to his role in ending legally enforced segregation in the South. In the initial period after his death, the mainstream media found no reason to discuss Malcolm $\mathrm{X}$ in any great depth until the 1980s. Although mainstream newspapers eventually came to appreciate Malcolm X, his image remained unsettling, hence their continuing significance for Obama's dilemma in 2008.

Initially historians followed the lead of the mainstream media, and depicted King and Malcolm $\mathrm{X}$ as alternatives. According to these historians, King was a nonviolent crusader against segregation in the South, while Malcolm X was an outspoken radical nationalist. Some of them, such as Harvard Sitkoff, still found Malcolm X an

\footnotetext{
${ }^{3}$ Given that Malcolm X made so much of his troubled upbringing later on in life, the best source on his youth is still Malcolm X himself, The Autobiography of Malcolm X, told to Alex Haley (London, 1968). Manning Marable's Malcolm X: A Life of Reinvention (New York, 2011) is probably the best secondary source on the subject, being one of the few biographies to display any original research into Malcolm X's childhood.

${ }^{4}$ Although King never produced an autobiography similar to Malcolm X's, he did write extensively on his own childhood in the South, and his later experiences as a university student. Clayborne Carson, editor of the King Papers Project at Stanford University, has combined King's autobiographical writings, speeches, and other primary source material to create The Autobiography of Martin Luther King, Jr (London, 1999).
} 
important figure, while some did not. Sitkoff placed Malcolm X and King within the same movement for black equality, but still made them appear rivals for leadership of it. ${ }^{5}$ Stephen Oates, an admiring biographer of King, briefly mentioned Malcolm X, arguing that Malcolm X's main contribution was to provide an undesirable alternative to King, who viewed the Nation as a malignant by-product of white supremacy. Oates acknowledged Malcolm X's break with the Nation, but ascribed to him little motivation beyond "jealousy" for King's success. ${ }^{6}$ Orthodox scholarship looking at the era assumed King and Malcolm X were separate and uninterested in each other, and did not regard the relationship itself as worthy of study.

The first effort to challenge orthodox views of King emphasised the last three years of King's life. King's greater focus on poverty, his anti-Vietnam War activism, and his more urgent rhetoric, beginning after 1965, receive greater attention from these historians. Some, such as David Garrow, have argued that during the last years of King's life, the political establishment regarded him as a more radical, even dangerous figure. ${ }^{7}$ Adam Fairclough documented King's opposition to the Vietnam War well, but focused on the period between 1965 and 1967, without much attention to the years leading up to that point that made King so uncomfortable with the war. ${ }^{8}$ Although historians like Fairclough appreciated that King's opposition to the war was consistent with much of his earlier activity, they have largely failed to examine King's earlier anti-war activities in any detail. These historians have depicted King's later years as a deviation from his earlier activities, rather than an extension of them.

Recent depictions of King have argued that King's apparently newfound radicalism was in fact entirely consistent with the worldview of the younger King. Led by Clayborne Carson, editor of the King Papers Project at Stanford University, recent scholarship has shown King held many of his radical interests from his university

\footnotetext{
${ }^{5}$ Harvard Sitkoff, The Struggle for Black Equality 1954-1980 (New York, 1981), pp. 154155.

${ }^{6}$ Stephen Oates, Let the Trumpet Sound, pp. 244-246, 330-331.

${ }^{7}$ David Garrow, The FBI and Martin Luther King, Jr.: From "Solo" to Memphis (New York, 1981), pp. 213-214.

${ }^{8}$ Adam Fairclough, 'Martin Luther King, Jr. and the War in Vietnam', Phylon, 45:1 ( $1^{\text {st }}$ Qtr., 1984), pp. 19-39.
} 
days. ${ }^{9}$ Thomas Jackson also argued that the continuity rather than the change of this worldview is what is truly striking about King's life. ${ }^{10}$ Unlike most early historians of the civil rights era, Carson and some of his contemporaries are former participants in the black protest movement themselves. Carson, for instance, is a former member of the Student Non-Violent Co-ordinating Committee, an influential black protest organisation in the 1960s. Thus, King scholarship began by confining King's importance to the South. Later biographies acknowledged King's last years as a more troublesome figure for mainstream American. The most recent scholarship has gone a step further, and argued that King's activism in his last three years was in fact a direct extension of his work previously.

Most revisionists have emphasised King's radicalism by comparing him with Malcolm X. The key text for the convergence of King and Malcolm X was James Cone's Martin \& Malcolm \& America, in which Cone argued that King and Malcolm $\mathrm{X}$ were close, not just politically but also personally, and were well aware that they were part of the same larger movement. According to Cone, the pair made a conscious effort to play the roles that the mainstream news media had assigned them, since both anger and conciliation were important roles to play. For King, this meant appearing as a moral leader and visionary for a fully integrated America. For Malcolm X, this meant publicly attacking King from the sidelines. Cone argued that the media was crucial in establishing them as contradictory figures:

Although the media portrayed them as adversaries, Martin and Malcolm were actually fond of each other. There was no animosity between them. They saw each other as a fellow justice-fighter, struggling against the same evil - racism - and for the same goal - freedom for African-Americans. ${ }^{11}$

Cone's work acknowledged that the media exaggerated the extent to which King and Malcolm X opposed each other, and suggested that their disagreements were, in reality, minor.

\footnotetext{
${ }^{9}$ See for example, Clayborne Carson, 'Introduction', The Papers of Martin Luther King Volume VI: Advocate of the Social Gospel, September 1948-March 1963 (Berkeley, 2007), pp. 4-5.

${ }^{10}$ Thomas Jackson, From Civil Rights to Human Rights (Philadelphia, 2007), pp. 1-14.

${ }^{11}$ James Cone, Martin \& Malcolm \& America: A Dream or a Nightmare (Maryknoll, 1991), p. 2.
} 
The Autobiography of Malcolm X, originally published months after its subject's death in 1965, exerts a strong influence on historians who write about King and Malcolm X converging. It also holds remarkable influence over scholarship of Malcolm X himself, and very few biographies of him have displayed extensive research beyond it. ${ }^{12}$ The result of a collaboration between Malcolm X and journalist Alex Haley and released not long after its subject's assassination, the autobiography depicted the differences between King and Malcolm X to be closing. ${ }^{13}$ The narrative of the autobiography emphasised transformations in Malcolm X's life: that he was first a petty criminal, then an outspoken minister, and finally a pan-African humanist ready to work with King and his colleagues for black freedom. To Cone, one of the many historians influenced by the autobiography, the perceived differences between King and Malcolm X were simply the function of their public relations strategies. Other historians have focused on either King or Malcolm X, and made passing reference to their similarity to the other. Jackson, for instance, argued that journalists placed King "in dualistic opposition" to Malcolm X, despite similarities in their concerns. ${ }^{14}$ Michael Eric Dyson wrote biographies about both Malcolm X and King that placed them closer to one another politically, emphasising King's radicalism when writing about King, and arguing that mainstream appropriation of him made Malcolm X more important. ${ }^{15}$

One of the only scholars to go beyond Cone's model of convergence was Manning Marable. Marable conveyed this divergence by going beyond The Autobiography of Malcolm X's narrative of transformation. Marable argued that Haley had deliberately placed Malcolm X's break with the Nation as part of a move by Malcolm X towards the mainstream civil rights movement as represented by figures such as King. ${ }^{16}$ To Marable, Malcolm X's break with the Nation was more complicated than that. Like Cone, Marable argued that Malcolm X aimed to provide a voice that represented those

\footnotetext{
${ }^{12}$ Malcolm X, with Alex Haley, The Autobiography of Malcolm X (London, 1968).

${ }^{13}$ Carson, 'The Unfinished Dialogue of Martin Luther King, Jr. and Malcolm X', $O A H$ Magazine of History, 19:1 (January 2005), p. 22.

${ }^{14}$ Jackson, p. 7.

${ }^{15}$ Michael Dyson, Making Malcolm: The Myth and Meaning of Malcolm X (Oxford, 1995), pp. 26-27; Dyson, I May Not Get There With You: The True Martin Luther King, Jr. (New York, 2001). See also Vincent Harding, 'Beyond Amnesia: Martin Luther King, Jr., and the Future of America', Journal of American History, 74:2 (September 1987), p. 469.

${ }^{16}$ Marable, pp. 9-10.
} 
outside the middle-class, integrationist mainstream of the black protest movement. ${ }^{17}$ Unlike Cone however, Marable argued that these differences reflected the fact that they occupied different African-American responses to white racism, and were working towards different, though not mutually exclusive, goals. King was a primarily American figure aiming to transcend racial divisions, while Malcolm X remained steadfastly black in his identity. King aimed to overcome white racism and attain full American citizenship for African Americans, while Malcolm X aimed at indicting whites to build a solidly black and militant constituency. Marable claimed the argument that Malcolm X was similar to King oversimplified his break with the Nation, and did a disservice both to King and Malcolm X's roles by conflating their goals. $^{18}$

Newspapers are vital resources that shed light on the factors creating public consciousness. This thesis examines how black and mainstream newspapers explained King and Malcolm X's significance and symbolic value to their readers. Neither black nor mainstream newspapers were blank slates on the news. Their ideological commitments, economic strategies and previous frames of reference shaped their representation of King and Malcolm X when they first appeared on the national scene, and continue to shape there representation of them today. ${ }^{19}$ Under the influence of their previous representations of the two men, newspapers were slow to revise their images of King and Malcolm X. Nonetheless, as their ideological commitments changed, and as the expectations of their readers changed, newspapers, both black and mainstream, represented King and Malcolm X differently.

This thesis looks at seven newspapers chosen to provide a geographic cross-section and a comparison of mainstream and African-American newspapers. The mainstream newspapers are the New York Times (NYT), Washington Post (WP), and Los Angeles Times (LAT). The NYT has always been seen as the definitive newspaper of record for American history. The WP is a newer, less established newspaper close to the United States government. The paper is also closer to the South, leading it to report on events near it, especially in the Virginia region. Based on the opposite coast, the LAT was a

\footnotetext{
${ }^{17}$ Ibid., p. 479.

${ }^{18}$ Ibid., pp. 480-483.

${ }^{19}$ A. C. H. Smith, with Elizabeth Immirzi \& Trevor Blackwell, Paper Voices: The Popular Press and Social Change: 1935-1965 (London, 1975). p. 12-11.
} 
more conservative newspaper until 1960, when it became more liberal under new publisher Otis Chandler.

The black newspapers studied are the New York Amsterdam News (NYAN), Atlanta Daily World (ADW), Chicago Defender (CD) and Los Angeles Sentinel (LAS). The black newspapers studied, for the most part, were closely tied to black protest. The NYAN, CD, and the $L A S$ are three of the largest black newspapers in the country. The NYAN and LAS are weekly newspapers, and the $C D$, for the period that it was available for this thesis, was a daily paper like the $A D W$. All of them, during the time period, inserted King and Malcolm X into the framework of continuing black protest. Most of them advocated fiercely on behalf of the black protest movement, although the $A D W$, like many Southern black newspapers, proved to be much more cautious in its coverage. $^{20}$

The term "black press" refers to news written of, by, and for African Americans. Black newspapers have generally been more openly political than their mainstream counterparts, often taking a critical view of American society. Initially, the black press was heavily involved in abolitionism, aiming to provide a black voice within the white-dominated movement. Their content was also much more varied than mainstream newspapers, often with a less clear division between news and opinion. ${ }^{21}$ This study examines it at a time when its power declined steadily, as mainstream newspapers granted more coverage to African-American perspectives. The black press's role has generated controversy, due to the perception that black newspapers cater to members of the black middle class. African-American sociologist Franklin Frazier in 1957 attacked the black middle class for its efforts to appear as white as possible, at the expense of taking more pride in being African American. According to Frazier, the black press was a key part of maintaining the black bourgeoisie's

\footnotetext{
${ }^{20}$ The ProQuest Historical database had an incomplete run of the $A D W$ and the $C D$. The $A D W$ was unavailable from June 1964 until January 1968, and then from January 1968 until January 1970, meaning that almost no coverage on the later careers of King and Malcolm X was available for the $A D W$. The $C D$ had a full run throughout King and Malcolm X's lifetimes, but was only available until 1975, meaning it was of limited use for Chapter Two, and no use for Chapter Three.

${ }^{21}$ Patrick Washburn, The African American Newspaper: Voice of Freedom (Evanston, 2006), pp. 1-9.
} 
"world of make-believe", and essentially middle-class in its outlook. ${ }^{22}$ Rejecting their own black roots, and rejected by the white mainstream, Frazier wrote that members of the black bourgeoisie were losing their identity. He scorned a press that contributed to this process, suggesting an essentially conservative media hostile to radicalism and unwilling to write for and on behalf of lower-class African Americans.

More recent scholarship has argued that black newspapers have been closely aligned with the black protest movement since the first black newspaper appeared. ${ }^{23}$ Gene Roberts and Hank Klibanoff argued that until around the late 1950s, the black press provided better coverage of racial protest. ${ }^{24}$ Historians such as Armistead Pride, Clint Wilson and Patrick Washburn argued that the black press was an instrument of protest. ${ }^{25}$ Patrick Washburn claimed the activism of the black press before Brown $v$. Board of Education helped inspire the black protest movement. ${ }^{26}$ Charlotte O'Kelly argued that as the black protest movement developed, the editorial content of these newspapers evolved accordingly. As certain black protest organisations garnered more support, O'Kelly argued the black press followed in granting them more coverage. If a certain theme, such as ending legal segregation, declined in importance to the black community, the black press de-emphasised it. Overall, though, the continuity, rather than change, in those concerns is what O'Kelly found striking. O'Kelly argued, for instance, that "economic integration" remained prominent in black newspapers throughout her period of study: the black protest movement from 1946 to $1972 .^{27}$

Mainstream newspaper reporters and editors tend to endorse centrist values and favour the existing political order. This leads them to mistrust radical ideas on either the right or the left of the political spectrum. They are also likely to have a "romanticised" image of America's past and political traditions, and support the

\footnotetext{
${ }^{22}$ Franklin Frazier, Black Bourgeoisie: The Rise of a New Middle Class New York, 1957), pp. $174,189$.

${ }^{23}$ Charlotte O'Kelly, 'Black Newspapers and the Black Protest Movement: Their Historical Relationship, 1827-1945', Phylon 43:1 (1 ${ }^{\text {st }}$ Qtr., 1982), pp. 1-14.

${ }^{24}$ Gene Roberts \& Hank Klibanoff, The Race Beat: The Press, the Civil Rights Struggle, and the Awakening of a Nation (New York, 2006), pp. 12-13.

${ }^{25}$ Armistead Pride \& Clint Wilson, A History of the Black Press (Washington, D.C., 1997).

${ }^{26}$ Washburn, pp. 1-9.

${ }^{27}$ O'Kelly, 'Black Newspapers and the Black Protest Movement, 1946-1972', Phylon 41:4 (4th Qtr., 1980), p. 324.
} 
prevailing political and economic arrangements. ${ }^{28}$ Rather than being an objective publication, it is up to the journalists and editors to decide what is important and whose side of a story to quote. Although newspaper articles give the impression of being separate from opinion, the manner in which articles are compiled nonetheless transmit subjective images to the reader, images which can change over time. ${ }^{29}$ As centrist values change, mainstream newspapers must revise their news coverage accordingly. Since the existing order is mainly white and male, the mainstream media only supports the goals of African Americans when they try to enter into it, and not when they try to resist, leading them to favour a conciliatory, integrationist approach to black protest. ${ }^{30}$

Other scholars have also focused on the role of newspapers within the black protest movement, some looking at coverage of discrete events within the movement, others taking a broader view of the movement. Craig Fluornoy argued that, contrary to expectations that the NYT provides the best news coverage, black newspapers such as the Birmingham World $(B W)$ generally provided better coverage of early civil rights events when they occurred locally, such as the Montgomery Bus Boycott. ${ }^{31}$ Fluornoy argued that the NYT focused on the Boycott as a legal rather than a popular challenge to segregation. Fluornoy noted, for instance, that there is no evidence that the NYT's reporters tried to report African-American perspectives of the protest movement. In contrast, the $B W$ quoted both black and white participants, including King, and focused on the event as a popular protest. Stacey Settle compared coverage of King's 1963 Birmingham campaign and the 1965 Selma to Montgomery voting rights marches in the $A D W$ and the Atlanta Constitution ( $A C$ ), a moderate mainstream newspaper, finding no major differences between the two papers. ${ }^{32}$ Local black newspapers were more likely than national papers to include black perspectives even when, as was the case for the $A D W$, its editorial stance was often more conservative than the mainstream newspapers like the $A C$ and the $N Y T$.

\footnotetext{
${ }^{28}$ David Paletz \& Robert Entman, Media Power Politics, (New York, 1981), p. 14.

${ }^{29}$ Ibid., p. 6.

${ }^{30}$ Herbert Gans, Deciding What's News: A Study of CBS Evening News, NBC Nightly News, Newsweek and Time (London, 1980), p. 61.

${ }^{31}$ Craig Fluornoy, 'Reporting the Movement in Black and White: The Emmett Till Lynching and the Montgomery Bus Boycott', Dissertation, Louisiana State University and Agricultural and Mechanical College (2003).

${ }^{32}$ Ibid., p. 174.
} 
While historians have studied newspapers' role in reporting the black protest movement, and while they have studied King and Malcolm X's relationship, few of them have compared representations of King and Malcolm X, and fewer still have traced those representations beyond King and Malcolm X's deaths. ${ }^{33}$ Instead, most historians accept it as a truism that King and Malcolm $\mathrm{X}$ were represented as polar opposites during their lifetimes. They also claim that, although Malcolm $\mathrm{X}$ is more appreciated today, the sanctification of King means that the two are thought of as more different than similar. Drawing from an online database of thousands of newspaper articles, this thesis looks at a part of the mainstream media to illuminate how these portrayals emerged, how they evolved, and how they have become entrenched.

In order to trace change over time, the chapters follow a primarily chronological organisation. The first chapter looks at King and Malcolm X during their careers. Both men posed different sets of difficulties for newspapers throughout their careers. Concerned about the possibility of racial violence, mainstream and black newspapers contrasted King and Malcolm $\mathrm{X}$ to one another, and struggled to convey King and Malcolm X's worldviews accurately. Mainstream newspapers tended to confine King's concerns to the South, and to dismiss Malcolm X as a demagogue. Black newspapers had a more complex relationship with both men. While they appreciated better King's radicalism, they could not understand why he protested the Vietnam War. As for Malcolm X, they could not decide between rejection and acceptance, and simultaneously welcomed his radical critique while worrying about the violence of his rhetoric.

The second chapter covers their assassinations, and then the period after that until 1983, when King's birthday became a national holiday. Newspapers gave both King

\footnotetext{
${ }^{33}$ One of the few to look at the relationship at all is Joshua Grimm, who compared the coverage of King and Malcolm X in the NYT over the period of 1960 to 1965, and argued that the paper's framing endorsed King's leadership, while rejecting Malcolm X's. This thesis builds on Grimm's by incorporating other newspapers, including the black press, and by extending the dates covered to the contemporary period. Joshua Grimm, 'Mirror, Mirror: Hegemonic Framing of Malclolm X and Martin Luther King, Jr. in the New York Times', Student paper, International Communication Association Annual Meeting in San Francisco, 2007.
} 
and Malcolm X's deaths extensive coverage, more coverage in fact than either man had earned in his lifetime. After he died, King quickly became a universally admired figure. His commitment to nonviolence and his effectiveness as a leader allowed newspapers to remember him favourably as the black protest movement became more violent and diffuse. The anniversaries of both King's birth and death were quickly commemorated, and a movement quickly formed to make the former a federal holiday. Malcolm X's immediate afterlife was less public. Newspapers covered the investigation into his murder, and the release of his autobiography provided a basis for further recognition, but the level of that recognition remained lower than it had been during his lifetime, and much lower than the level King received. As newspapers contributed to the construction of a public memory of the civil rights movement, they emphasised King and left Malcolm X relatively obscured.

The third chapter picks up the story with the first federal Martin Luther King holiday, and finishes with the coverage of Spike Lee's 1992 film adaptation of The Autobiography of Malcolm X. The institutionalisation of King's memory, with the King federal holiday first observed in 1986, entrenched King as a national hero. Such commemoration had the effect of marginalising King's worldview, in much the same way that aspects of King's worldview had been marginalised early in his career. Malcolm X, however, underwent a dramatic resurgence. The 1990 documentary series Eyes on the Prize covered him favourably, and as King became a more benign figure Malcolm X became a more accessible shorthand for a more aggressive alternative. By this point, mainstream and black newspapers alike presented Malcolm X as having been a positive influence on the black protest movement. Lee's film, starring Denzel Washington in the title role, both reflected this newfound interest, and reinforced it, as the film garnered considerable attention and some controversy as well. At the end of the period, newspapers appreciated convergence in the ideologies of King and Malcolm X, but continued to separate their significance between the national King and the racial Malcolm X.

As the thesis will demonstrate in its conclusion, representations of King and Malcolm $\mathrm{X}$ continue to fit into broader conceptions of American racial ideology. These conceptions, often binary in nature, have continued to exert influence over any African American in the public eye to this day. The mainstream press depicted King 
as more legitimate than Malcolm $X$ while they lived. After they died, Malcolm $X$ slowly became more accepted as a protest leader, but his significance remained racial, rather than universal. While Malcolm X's association with anger and bitterness detracted from his standing as a leader in the eyes of the mainstream press, the black press viewed this anger as a positive attribute. Black and mainstream newspapers disagreed with each other over why King was so important. Mainstream newspapers emphasised King's significance for racial reconciliation, making him a leader of importance for all Americans. Black newspapers emphasised his importance only in terms of King's value to African Americans. This is why Obama has tried to align himself with King. As Malcolm X demonstrated, black leaders have found it difficult to appear angry and retain the sympathy of the mainstream media. By appearing more like King, Obama retained the support of the mainstream press while still seeming 'black'.

This thesis also highlights the fact that newspapers do not merely assign importance to certain causes, but have the power to marginalise them as well. In covering King and Malcolm X, the mainstream press demonstrated their uneasiness with the implications of poverty and racial inequality in urban centres. Similarly, King's concerns for the plight of Northern blacks were marginalised as mainstream newspapers downplayed those aspects of his worldview. Black newspapers proved to be better at granting coverage to King's concerns with poverty, but they too had blind spots, which they demonstrated when they expressed surprise at King's opposition to the Vietnam War. As the episodes involving Obama demonstrate, the difficulties in addressing the full scope of King and Malcolm X's legacies reflect the continuing existence of racial tensions and class inequalities in the United States. Studying the images of King and Malcolm X offers evidence that the United States has yet to become a post-racial society despite the election of Barack Obama. 


\section{Chapter One: "Two Ways"}

During their lifetimes, King and Malcolm X featured in the news in different ways. Both sought, with varying degrees of success, to shape their public images. Although both men were aware of the powers and limitations of newspapers and the news media in general, they also struggled at times with a public image that they did not necessarily want to have. Malcolm X found that associations with violence and black nationalism characterised the media's treatment of him as he moved toward reconciliation with the mainstream of the black protest movement. King's difficulties were less clear, but just as serious. Since both black and mainstream newspapers ignored inconvenient aspects of his worldview when they first wrote about him, they could not comprehend his anti-poverty and anti-Vietnam War activities. Throughout King and Malcolm X's lifetimes, newspapers generally portrayed the two as leading opposing sides of the black protest movement.

This chapter will show that newspapers, both mainstream and black, interpreted King and Malcolm X very differently at first, influenced by their differing priorities in racial issues. Mainstream newspapers emphasised the ways in which King fit within American and Christian traditions, while describing Malcolm $\mathrm{X}$ as part of a strange, cult-like organisation that was morally equivalent to groups like the Ku Klux Klan. Black newspapers focused on King's connections to his followers, while generally rejecting Malcolm X's approach as counterproductive. This chapter will also detail the manner in which newspapers established King and Malcolm X as mutually exclusive alternatives. While newspapers never assigned King and Malcolm X equal importance, they eventually came to represent them as alternative solutions to the problems of white supremacy. To mainstream newspapers, these alternatives were mutually exclusive, and anything but morally equal. African-American newspapers viewed the situation as more complex. They shared mainstream concerns about the prospects of racial violence and distrusted Malcolm X for that reason. This chapter will conclude by exploring newspapers' continued lack of interest in Malcolm X's worldview, and their realisation that King, too, had radical ideas they did not share. 


\section{$\underline{\text { Early images }}$}

Newspapers assigned King and Malcolm X different roles when they first appeared on the national scene, fitting King and Malcolm X within newspapers' broader preconceptions about American race relations at the time. King quickly rose to prominence when he was chosen to lead the Montgomery bus boycott, a year-long boycott commenced in December 1955 in protest against racial segregation on city buses in Montgomery, Alabama. The success of the boycott, which relied on almost total popular support from Montgomery's black community, propelled King to the attention of the national media.

One could reasonably expect the mainstream news media to find King's leadership during the boycott difficult to interpret. Although intelligent and well presented, King was a young, almost completely unknown man when he led the boycott. The boycott itself caught most of the mainstream media by surprise, and the main impetus for it came not from an established hierarchy of black leaders, but from the so-called 'rank and file' black citizens of Montgomery who were harder for newspapers to identify or interview. Mainstream newspapers sidestepped this difficulty by focusing on the boycott's legal aspects. The New York Times (NYT) still covered King, profiling him four months into the boycott, but most of the paper's reports covered legal battles in Montgomery's courthouses, not its streets. Montgomery presented an issue for papers like the NYT, as African Americans assumed a leading role usually denied to them. The NYT used fewer sources, and was less likely than the Birmingham World, a black paper, to quote African Americans. ${ }^{34}$ By the end of the Boycott, however, both the mainstream and African-American press had anointed King as a new nationwide leader of the civil rights movement, which removed the need for the mainstream press to figure out how to frame a popular movement rather than a hierarchical organisation with a single leader.

The mainstream news media, attempting to make sense of the emerging movement, tried to whiten the black protestors. In its early profiles of the Montgomery

\footnotetext{
${ }^{34}$ Craig Fluornoy, 'Reporting the Movement in Black and White: The Emmett Till Lynching and the Montgomery Bus Boycott', Dissertation, Louisiana State University and Agricultural and Mechanical College (2003), pp. 166-167.
} 
movement, the NYT emphasised the role of the Supreme Court, economics, federal policies, and education - primarily white influences that the typical white middleclass reader could understand. ${ }^{35}$ The $N Y T$ also initially overestimated the white south's willingness to comply with desegregation. ${ }^{36}$ It also associated King himself with primarily white influences, describing his appreciation for philosophers like Hegel and Kant, and his fondness for classical music, although his debt to Gandhi was also mentioned. ${ }^{37}$ Early mainstream depictions of King projected the image of a scholarly, well-presented, understated yet authoritative leader. In its early profile of him in March 1956, the NYT commended King for being:

a rather soft-spoken man with a learning and maturity far beyond his twenty-seven years. His clothes are in conservative good taste and he has a small trim mustache. He heads an upper middle-class group of Negro Baptists with dignity and restraint.

This description set the tone for a profile that detailed King's education, rhetorical abilities, philosophy, and social class. The article featured a picture of King in suit and tie, with the reassuring caption "all men are basically good." 38

Meanwhile, the black press focused on King's personality and connections with African-American communities. When the New York Amsterdam News (NYAN) and Los Angeles Sentinel (LAS) profiled the young King, his European influences were absent, as they emphasised Christianity, particularly African-American Christianity, and Gandhi. ${ }^{39}$ In formulating their early images of King, nonviolence remained at the back of the minds of the mainstream media, while for the black press it was important as a political weapon and because it might avert racial violence. The NYT's main interest with King's education and respectability; the NYAN, emphasised his closeness to his people and leadership ability.

\footnotetext{
${ }^{35}$ George Barrett, 'Jim Crow, He's Real Tired', NYT, 3 March 1957, p. 11.

${ }^{36}$ Gene Roberts \& Hank Klibanoff, The Race Beat: The Press, the Civil Rights Struggle, and the Awakening of a Nation (New York, 2006), p. 111.

37 'Battle Against Tradition', NYT, 21 March 1956, p. 28; George Barrett, 'Montgomery:

Testing Ground', NYT, 16 December 1956, p. 48.

38 'Battle Against Tradition', NYT.

${ }^{39}$ James Booker, 'Who is Martin Luther King?', NYAN, 31 March 1956, p. 2; 'A New Kind of Negro Leader', LAS, 31 October 1957, p. C7.
} 
The black press also identified, more clearly than the mainstream papers, a clear foe in King's struggle: the white South. They still believed in racial reconciliation, but they had little faith in the capacity of white southerners to dismantle Jim Crow laws voluntarily. While the mainstream newspapers depicted King as a leader for a new south, which could be brought about by a coalition of black and white moderates, black newspapers did not emphasise his effect on whites. In fact, King's strategy was so valuable because, according to the black press, it was so incomprehensible to the white southern enemy. In early profiles of King, the LAS and the NYAN both lauded King's strategy in part because white southerners were unable to "understand" it. ${ }^{40}$

Malcolm X's first appearances in the national news media were less clear than King's. The 1959 documentary The Hate that Hate Produced, rather than a national news event, brought Malcolm X and the Nation of Islam to national attention, although the black press in New York had been acknowledging their activities for years by then, with the NYAN mentioning Malcolm X as early as $1957 .{ }^{41}$ At no time in Malcolm X's life did he achieve a level of popularity that approached King's. In some mainstream newspapers, and indeed to some black newspapers, he received only fleeting mention. The difference between mainstream and black press covering Malcolm X was most stark in the New York papers that mentioned him most often, as the weekly NYAN mentioned Malcolm X more often than the daily NYT (see Figure 1.1). Exacerbating the lack of a single, Montgomery-like event to announce Malcolm X nationally, he was also harder still for the mainstream media in particular to interpret. To say nothing of his public contempt for most popular black leaders, his Muslim religion, criminal history, lack of formal education, and mysteriously single-lettered surname all made it difficult for the white, middle and upper-class audience of mainstream newspapers.

\footnotetext{
40 'Who Is Martin Luther King?', NYAN; 'A New Kind of Negro Leader', LAS.

41 'Mr. Malcolm X At New York Temple Sunday’, NYAN, 5 January 1957, p. 3.
} 


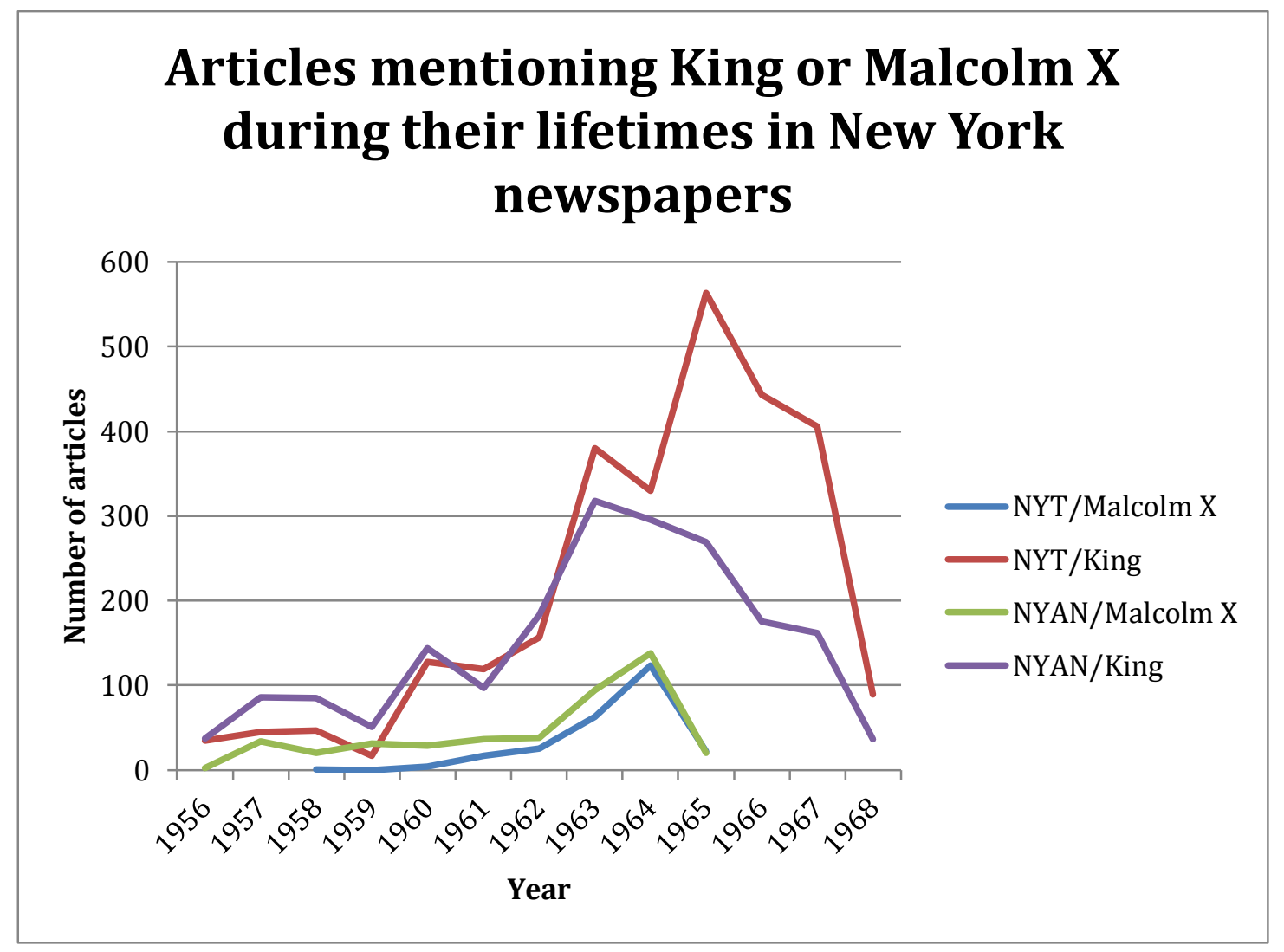

Figure 1.1

Wanting to discover more about the Nation, the Washington Post (WP) sent a young black reporter, Wallace Terry, to investigate the organisation in 1960. The resulting six-part feature, published in December 1960, introduced the Nation to the WP's readers. ${ }^{42}$ The articles mentioned violence, but not as strongly as later reports on Malcolm X. Instead, the WP framed the Nation as an anti-white organisation. The first article in the series caught the reader's attention with the headline, 'A 'Messiah' Preaches Hate of White Man to 70,000 'Black Muslims', maintaining the theme of racial disharmony in The Hate that Hate Produced. ${ }^{43}$ Most of the articles in the series mentioned Malcolm X, but the series focused more heavily on the titular 'Messiah' and the Nation's leader, Elijah Muhammad. All the same, the WP identified the Nation, and therefore Malcolm X himself, with hatred of white people.

${ }^{42}$ Wallace Terry, 'A 'Messiah' Preaches Hate of White Man to 70,000 'Black Muslims', WP, 11 December 1960, p. E3; 'Black Muslim Elijah's Lowly Start', WP, 12 December 1960, p. A3; 'Injustices Stressed for Black Muslims', WP, 13 December 1960, p. B3; 'Members Face Rigid Tests In Joining Black Muslims', WP, 14 December 1960, p. B8; 'Black Muslims Told They're 'Chosen People', WP, 15 December 1960, p. B12; 'Black Muslims' Hate Campaign Criticized', WP, 16 December 1960, p. A18.

43 'A 'Messiah' Preaches Hate of White Man to 70,000 'Black Muslims', WP. 
The introduction described the Nation as a strange, and above all, secretive, group. Under the lead-in, "cult of hate", the WP introduced members of the organisation:

Only a few words and nods passed among the group. When white teenagers approached, the cadence quickened and the little figure in the middle was hurried through the exit to a waiting motorcade. 'Ay-SalaamAlakem. Ay-Salaam-Slakem.' Snappy military salutes accompanied the Arabic greetings of peace. The drivers quickly opened the doors of the late model cars and the party climbed in. The man they protected as if he were in mortal danger paused only to clasp the hands of one and say, 'Brother, it is good to see you again. All praises be unto Allah. ${ }^{44}$

The article immediately evoked a sense of mystery about the group that would pervade the remainder of its coverage. The group was reclusive and perhaps sinister in its practice. The article ironically contrasted the "military" salutes, and the peaceful content of the Arabic greeting. While King and his colleagues were Christian, often northern-educated and European-American influenced, and non-threatening, this "cult" was foreign in its language, style, and religious influences - a dangerous image for the political elites likely to read the WP.

The series presented the Nation as the antithesis of integrationism. The first article began by describing a group of Black Muslims, headed by Muhammad, visiting Atlanta, noting that their physical similarity to associates of King, and then contrasting it with their ideological opposition to King. Terry wrote ironically, "many in the crowd of white passengers thought they were desegregationists on their way to confer with the Rev. Dr. Martin Luther King. Desegregation, in fact, was the last thing on [their] minds..."45 The series extensively used the Nation's black critics in its final article, quoting the Urban League's executive leader Edwin Berry and National Association for the Advancement of Colored People (NAACP) leader Roy Wilkins, providing a contrast to the separatist Nation. The WP preferred the term "segregationist", equating the Nation with King's southern opponents, to present the Nation as an undesirable alternative to the moderate integrationist approach. The end of the series provided the argument, as put by the Urban League's Berry, that

\footnotetext{
${ }^{44}$ Ibid.

${ }^{45}$ Ibid.
} 
Muhammad was "a manifestation of our own illness... and we're so sick we don't know about it. In any society where prejudice and discrimination can become the norms, you really can't get much sicker." 46 Like The Hate that Hate Produced, the WP argued the Nation was the inevitable product of white supremacy, and a cautionary tale of what could become common should the integrationist side of the civil rights movement fail - a view that became more popular with the mainstream press later on.

The Nation of Islam provided Malcolm X with an institutional and organisational basis for his work and his public image. In 1960 newspapers increased their coverage of the Nation in relation to the black protest movement. Malcolm X was often quoted in news reports communicating the Nation's views, helping identify him with the Nation. ${ }^{47}$ Eventually his quotes became the focus of stories in their own right, but for the time being it was only his role within the Nation that interested reporters. ${ }^{48}$ These early stories emphasised the Nation's views on black supremacy rather than violence. Initially the main reason behind Malcolm X's news presence was his role within the Nation of Islam.

The media deployed the Nation of Islam to symbolise an undesirable alternative to the mainstream civil rights movement. The Nation's regular rallies ensured a steady supply of events on which newspapers could report and national membership, which existed in several urban centres, provided a base that elevated its potential significance. While there were other voices within the civil rights movement expressing views that made mainstream newspaper editors uncomfortable, none had an organisation quite like the Nation. Malcolm X's position within the group, as a chief spokesman and organiser for the New York Mosque, helped him gain access to the NYT. Malcolm X eventually became, for the black and the mainstream press, the favoured individual for a quote or story on the Nation. His inclination towards making controversial statements, and Muhammad's reticence on everyday political issues,

\footnotetext{
46 'Black Muslims' Hate Campaign Criticized', WP, 16 December 1960, p. A18.

${ }^{47}$ For a story about the Muslims, predominantly quoting Malcolm X, see 'Muslims Say:

"Welcome" to Probe!', NYAN, 25 August 1962, p. 1; 'Moslems Hurl Charges at State Prison Rule', NYAN, 7 November 1959, p. 1; 'Muslim Charges Englewood Sham', NYT, 6 August 1962, p. 27; 'Muslim Talk Approved', NYT, 23 November 1961, p. 50.

${ }^{48}$ Les Matthews, 'Muslim Calls U.S. "A Police State”, NYAN, 23 February 1963, p. 1;

'Malcolm X Assails Racial Integration', NYT, 14 July 1963, p. 50.
} 
meant that he was often the only prominent voice for the Nation in the media and he became a go-to figure who evolved into King's negative alter ego, just as the Nation had been used as the undesirable alternative to the civil rights movement.

Malcolm X's increasing prominence included a heightened association with violence. His most provocative and quoted comments tended to relate to violence, which he spoke about with significantly less foreboding than did King. Initial portraits of the Nation, in the WP and elsewhere, had depicted the organisation as secretive and racist in its nature, but the threat of violence was not prominent in these articles. It was not Malcolm X's association with the Nation of Islam that linked him with violence, but rather the inverse. As the newspapers covered Malcolm X, his indirect association with violence tainted the Nation.

Malcolm X's proclivity for making incendiary statements enhanced his public image as well as detracting from it. His public image, as Malcolm $\mathrm{X}$ himself was aware, could sometimes be counterproductive, and his public statements did not always help. All the same, a large part of Malcolm X's appeal to African Americans was that he articulated resentment and anger that they felt unable to express themselves. In the words of C. Sumner Stone, a New York editor, in reference to Malcolm X, "The N.A.A.C.P. and the Urban League are doing a good job, but are not emotionally satisfying... They give out soothing words. When you're angry, you want to hear angry words." ${ }^{49}$ This meant that Malcolm X was unlikely to find favour in the mainstream as well as conservative black newspapers even as he gained a popular following among younger and more radical blacks.

Early images of King and Malcolm X did not indelibly define their images later on. As will be shown, the representation of King in particular changed noticeably with time. Nonetheless, these portrayals exercised significant influence on later developments. After his break with the Nation, newspapers - both black and white often failed to re-evaluate their pre-existing images of Malcolm X, preferring to use the existing frame rather than adapt to a more fluid reality. Although King would always be associated with nonviolence, his image slowly changed to that of one trying

\footnotetext{
${ }^{49}$ Michael Clark, 'Rise in Racial Extremism Worries Harlem Leaders', NYT, 25 January 1960, p. 18.
} 
to avert violence, or worse yet someone who, though he was not violent, would nonetheless precipitate violence. With King, early images laid the foundation for a positive image, but one that primarily associated King with the civil rights struggle in the South. Meanwhile, Malcolm X started with a negative perception, which he found hard to escape.

\section{Alternatives}

The divergent mainstream frames relating to King and Malcolm X derived from the fear that other forces less acceptable to the mainstream media might take over the black protest movement should King's strategy fail. Malcolm X became a particularly useful foil, as the mainstream press cemented their endorsement of King's leadership by implying that Malcolm $\mathrm{X}$ and the Nation were the main alternatives to King. Unlike most of the other 'radical' leaders, Malcolm X claimed no interest in associating with civil rights, and his public statements described Northern racism, uncodified in law, to be at least as malevolent as Jim Crow. By focusing on de facto racial oppression rather than de jure forms in the southern states, Malcolm X posed more of a direct challenge to the home bases of mainstream newspapers than did King, at least until King moved in 1965 to extend his civil rights movement to northern cities.

Newspaper editors were not the only people to expound the view that Malcolm X was a more extreme alternative to King. Among others, it appealed both to the Kennedy administration and to Malcolm X himself. During King's Birmingham campaign of 1963, John F. Kennedy used the threat of the Nation of Islam to persuade a group of Alabama newsmen to be more sympathetic to King. Malcolm X criticised Kennedy's argument, "Kennedy did not urge that Negroes be treated right because it is the right thing to do. Instead, he said that if the Negroes aren't well treated the Muslims would become a threat." ${ }^{50}$ After breaking with the Nation, however, Malcolm X provided the same explanation to King's wife, Coretta Scott King, "If the white people realize what the alternative is, perhaps they will be more willing to hear Dr. King." ${ }^{51}$ While he had

\footnotetext{
${ }^{50}$ M.S. Handler, 'Malcolm X Scores JFK on Racial Policy', NYT, 17 May 1963, p. 14.

${ }^{51}$ Clayborne Carson (ed.), The Autobiography of Martin Luther King, Jr. (London, 1999), p. 268.
} 
not appreciated the idea that he was simply the bogeyman used to benefit King's strategy, he nonetheless came to express a similar view.

The media found other symbols to represent the alternative approaches between integration and separatism, supposedly typified by King and Malcolm X. Although King was the most commonly cited figure of non-violent integration, newspapers occasionally referred to leaders from other protest organisations, such as Wilkins. Malcolm X shared the 'extremist' side of the equation with a number of contemporaries. Most common among these was Adam Clayton Powell, Harlem's flamboyant African-American congressman. Also a Baptist minister, Powell had earned a reputation for attracting controversy with his public comments. Other figures sometimes described as more radical and thus undesirable included the author James Baldwin, whose attacks on white supremacy were often deemed "bitter" by the mainstream papers, and sometimes even John Lewis, Chairman of the Student Nonviolent Co-ordinating Committee, whose address to the March on Washington was deemed so radical that it had to be toned down to prevent several white clergymen from withdrawing from the protest unless Lewis softened some of his strongest language. ${ }^{52}$ King and Malcolm X served as convenient and widely understood polar opposites for those who uncritically accepted mainstream media portrayals.

Sometimes, the press made the dichotomy between King and Malcolm X explicit. In May 1963, for instance, the NYT published a feature on the civil rights movement that declared that African Americans faced 'Two Ways' of approaching their problems. One potential path, according to the paper, was that of moderation, or "integration", represented - according to this particular article - by the NAACP. The other path was what the paper termed "segregation", represented by Malcolm X and the Nation of Islam. Pictures of both Wilkins and Malcolm X accompanied the feature. Wilkins appeared next to an NAACP recruitment poster featuring Abraham Lincoln. By contrast, Malcolm X stood in front of a large photograph of Muhammad. The feature article represented the clearest statement by the NYT on what sort of regard it had for the Nation of Islam and Malcolm X. Using Wilkins to emphasise its opposition to the

${ }^{52}$ Carson, In Struggle: SNCC and the Black Awakening of the 1960s (Cambridge, 1981), pp. 93-94. 
Nation, the NYT did not just support the integrationist wing of the black protest movement, but more basically, it assumed the existence of only two mutually exclusive paths. ${ }^{53}$

The mainstream press sometimes communicated the apparent choice implicitly. A news story about one often ended with a quote providing an opposite viewpoint from the other. For instance, when King spoke in 1964 about his plans to "test" the 1964 Civil Rights Act - then the Civil Rights Bill - Malcolm X was quoted at the end of the WP's article, branding the civil rights legislation a waste of time. ${ }^{54}$ Although the article did not state that Malcolm X threatened King's leadership of the national movement, it nonetheless implied that this was the case. By transitioning from King, a declared supporter of the Bill, to Malcolm X, who claimed that there was essentially nothing the Johnson administration could do to resolve the problem, the WP implied that King and Malcolm X represented two opposed spokesmen within the black protest movement by the length of its discussion of King's strategy, it endorsed integration and the actions of the federal government in drafting civil rights legislation.

Black newspapers focused on Malcolm X primarily when he was a local news figure, as the LAS demonstrated over the Ronald Stokes shooting. In 1962 Stokes and several other members of the Nation were involved in a shootout with members of the Los Angeles Police Department (LAPD), resulting in Stokes's death. ${ }^{55}$ Malcolm X promptly flew out to Los Angeles to advocate on behalf of those who had been shot, generating press coverage in both the mainstream and black press. In general, the Nation's hierarchy responded to the shootings passively, helping to create tensions between Malcolm X and his colleagues within the Nation. ${ }^{56}$ In Los Angeles, the LAS greeted Malcolm X's dynamism and leadership with a mixture of openness and hostility, quoting him regularly in stories regarding the trials. The LAS also quoted Malcolm X as he accused the Los Angeles Time (LAT) of leaving out the cross-

\footnotetext{
${ }^{53}$ Gertrude Samuels, 'Two Ways: Black Muslim and N.A.A.C.P.', NYT, 12 May 1963, p. SM14.

${ }^{54}$ Steven Gerstel, 'Negro Leaders Plan Immediate Test of Rights Bill', WP, 20 June 1964, p. A12.

${ }^{55}$ Taylor Branch, Pillar of Fire: America in the King Years 1963-65 (New York, 1999), pp. 313.

${ }^{56}$ Manning Marable, Malcolm X: A Life of Reinvention (New York, 2011), pp. 221-223.
} 
examinations of witnesses. ${ }^{57}$ However, the $L A S$ also gave prominence to Malcolm X's critics, especially in one front-page article on his black critics, which did not quote Malcolm X at all. ${ }^{58}$ Once Malcolm X left Los Angeles upon the conclusion of the Stokes trials, the LAS largely ignored him. The LAS treatment of Malcolm X reflected what the NYAN demonstrated by its more extensive coverage: black newspapers were only inclined to view him favourably when he was more directly involved with their community. The incident also demonstrated that black newspapers were more capable of admiring Malcolm X's work than mainstream newspapers, whatever the setting.

The LAT viewed Malcolm X's involvement in the Stokes case negatively. At every opportunity, it referred to the Nation as "anti-white" or as a "cult". ${ }^{59}$ It expressed scepticism of the official Muslim version of events, often putting the word "brutality", when applied to the LAPD, in quotation marks. ${ }^{60}$ At the height of the controversy in June, it reported Malcolm X thanking God for the deaths of over 120 white Americans, most of them from Georgia, in a plane crash, declaring that he "[hoped] that every day another plane falls out of the sky". The paper also allowed the city's administration significant influence over its coverage. Upon receiving a tape of Malcolm X's remarks Mayor Sam Yorty, an enthusiastic defender of the LAPD, played the tape to a news conference, asking the media assembled to report Malcolm $\mathrm{X}$ 's comments. The $L A T$ duly obliged, and by putting the story on the front page, it allowed Yorty to discredit Malcolm X further, especially in the eyes of white readers. ${ }^{61}$ The $L A T$ 's reporting of the incident indicated the intention of maligning and marginalising both Malcolm X and the Nation.

In addition to drawing attention to Malcolm X's comments on white deaths, the LAT's editors could also contrast him to the preferable side of the black protest movement. When King visited Los Angeles in June 1962, not long after the Stokes incident, the LAT used his presence to discredit the Muslims further. The purpose of King's visit was to aid local voter registration drives, but the Nation dominated the LAT's

\footnotetext{
57 'Malcolm X Scores Metros Trial Stories', LAS, 29 November 1962, p. A2.

58 'Ministers Disown Muslims', LAS, 24 May 1962, p. A1.

${ }^{59}$ See for instance, 'Muslim Hatred Called Threat to Community', LAT, 7 May 1962, p. 32;

'The Muslim Incident: Two Juries Investigate', LAT, 20 May 1962, p. F5; 'Top New York Muslim Says L.A. Is on Trial', LAT, 4 May 1963, p. 8.

60 'Negro Rally Demands End to Police 'Brutality", LAT, 21 May 1962, p. 2.

61 'Yorty Assails Boast of Black Muslim Chief', LAT, 7 June 1962, p. A1.
} 
coverage of his impromptu press conference. When asked for his opinion on the Nation, King gave his usual answer. He criticised the organisation and repudiated Malcolm X's comments, reiterating his opposition to violence. At the same time, however, King emphasised that he was "more concerned with getting rid of the conditions that brought [the Nation] into being than I am with the organization itself." The paper printed this quote, but emphasised King's opposition to the Nation itself. The main headline of the article dealt with King's stand against racial violence. ${ }^{62}$ The $L A T$, unlike King, focused on the Nation itself, and not on King's priorities in empowering the African-American community in Los Angeles.

The Stokes incident illustrated two features of Malcolm X's public image. First of all, it confirmed that the mainstream news media rarely delved deeper than Malcolm X's violent rhetoric and support for black separatism. Associations with black supremacy and violence became so ingrained in the mainstream press's views on the Nation that they framed Malcolm X within those parameters. Malcolm X's proclivity for incendiary statements gave journalists a plentiful supply of quotations to serve this purpose. Secondly, the Stokes shooting demonstrated that the black press could differentiate between the national and the local Malcolm X. While his pronouncements from New York generated apprehension in the $L A S$ - if they generated anything at all - his activism on behalf of those involved in the Stokes murder case received a more enthusiastic response from the same paper.

Associations with violence became more important to newspaper reporting of both men as the prominence of violence increased in coverage of the black protest movement. Initially King was a Moses-like leader, with the total support of his followers. As the movement developed and fractured, newspapers began to focus more on whether King would be able to hold his followers to a nonviolent approach. This began as early as 1964, as King approached a campaign in St. Augustine, Florida. The NYT framed the coming campaign as a test of the nonviolent approach to, and thus King's leadership of, the civil rights movement. ${ }^{63}$ The press often used King as the leading black voice against violence. Appropriately enough, the best illustration of this came with the assassination of Malcolm X, when newspapers approached King

\footnotetext{
62 'Racial Violence Assailed by Dr. Luther King', LAT, 16 June 1962, p. 11.

${ }^{63}$ John Herbers, 'Critical Test for the Nonviolent Way', NYT, 5 July 1964, p. SM5.
} 
for a quote condemning violence as a political tool. ${ }^{64}$ King's association with nonviolence was especially helped by the fact that Malcolm X was so closely associated with violence.

Malcolm X often did not even need to do anything in order to be used to symbolise opposition to King and to tag other leaders as extremists. In June 1963, King bemoaned a lack of enthusiasm for civil rights on the part of most white Americans. At a similar time Adam Clayton Powell made a speech expressing a seemingly contradictory complaint about the presence of white people in policy-making positions for civil rights groups. The WP reported these divergent opinions in the same article, using King as the main subject of the story, and contrasting his rhetoric with that of Powell. Detailing the divergence between King and Powell, the Post summarised Powell's position: "whites in policy-making positions in civil rights groups should be removed because they could not be trusted to act quickly and that he respected Black Muslim leader Malcolm X although he disagreed with some of his views." 65 The journalist mentioned Malcolm X nowhere else, although King was quoted in reference to the Black Muslims. The reference to Malcolm X reinforced both Powell and Malcolm X's positions in the article as radical and more Afro-centric alternatives to King, whom the WP represented as a universally respectable leader and visionary.

By mid-1963, then, the mainstream press set up King and Malcolm X as alternative leaders of black protest. The associations of each man with nonviolent resistance or violent revolution led most newspapers to endorse one and reject the other. The only scenario in which newspapers would embrace Malcolm X's leadership was when he acted on a local stage, at which point black newspapers would take a more positive approach. By associating Malcolm X with the concerns of urban blacks, the newspapers also implicitly strengthened the association of King with the civil rights campaign in the South. When King began to move beyond that campaign, and when Malcolm $\mathrm{X}$ began to break from the organisation that initially made him famous, newspaper representations of the pair struggled to adapt.

\footnotetext{
64 'Malcolm X Killed at N.Y. Meeting', CD, 22 February 1965, p. 1; Douglas Robinson, 'Rights Leaders Decry 'Violence', NYT, 22 February 1965, p. 11; 'King Offers to Mediate in Black Nationalist Feud', WP, 1 March 1965, p. A2.

${ }^{65}$ Terry, 'Whites' Support of Rights Asked', WP, 24 June 1963, p. B3.
} 


\section{Later in life - misunderstood or better understood?}

Malcolm X found that upon his break with the Nation of Islam in early 1964, newspapers were unwilling to examine his ideological disagreements with his former organisation, as mainstream newspapers and most black newspapers continued to neglect or dismiss him. In public, Malcolm X's infamous comments on the November 1963 assassination of John F. Kennedy triggered his break with the Nation. Referring to Kennedy's assassination, Malcolm X remarked “chickens coming home to roost never made me sad". The Nation's leadership used the comments as a pretext to silence Malcolm X and ultimately force him out of the organisation. The comment did not cause a significant public outcry. The NYT reported the remark, and Malcolm X's subsequent censure by Muhammad, but it did not give the issue much significance. ${ }^{66}$ The WP did not even mention his comment until the following March. ${ }^{67}$ However, the speech provided a simple opportunity for the press to differentiate between the Malcolm X and the Nation in subsequent reports on the split. It fit in well with the newspapers' perceptions of Malcolm $\mathrm{X}$ as being anti-white and supportive of violence, and reinforced the mainstream press's rejection of Malcolm X.

The feud between Malcolm $\mathrm{X}$ and the Nation provided the best illustration of newspapers ignoring his worldview. The newspapers of the time, mainstream and black, overlooked Malcolm X's views on race in favour of the personal rift between the pair and the many threats of violence that were made before Malcolm X's assassination - and after it. This negligence towards ideology was consistent, regardless of how much significance a newspaper actually accorded Malcolm X. The Atlanta Daily World (ADW) barely mentioned him between his December 1963 suspension and assassination in February 1965, and did not refer to any ideological dissonance between Malcolm X and the Nation. The NYAN, similarly, found its front pages had ample space to cover the split between Malcolm X and Muhammad, but of this coverage centred on the sensational aspects of the split: Malcolm X's allegations of marital infidelity against Muhammad; the stories of Malcolm X's romantic history

\footnotetext{
66 'Malcolm X scores U.S. and Kennedy', NYT, 2 December 1963, p. 21; R. W. Apple Jr.,

'Malcolm X Silenced for Remarks On Assassination of Kennedy', NYT, 5 December 1963, p. 22.

${ }^{67}$ Dave Brady, 'Patterson ‘Wises up’ Black Muslim Clay', WP, 15 March 1964, p. C5.
} 
with one of the women involved in these stories; and, most extensively of all, the threats of violence between Malcolm X's followers and those loyal to the Nation. All these topics received extensive coverage at the expense of Malcolm X's evolving views on race, which went unacknowledged until the publication of his autobiography. The headlines of typical front-page articles covering the MalcolmNation split read: "Malcolm X Flees for Life; Muslim Factions at War", or "Home of Malcolm X is Fire-Bombed; No Injuries". ${ }^{68}$ As with the mainstream media, concerns about the possibility of violence remained in the forefront of the black press's minds.

A few months after Malcolm X's February 1965 assassination, King began to focus his efforts more publicly against targets outside his Southern area of concern. In mid1965 he criticised the American military build-up in Vietnam, a criticism that he drastically escalated in April 1967. In late 1965, King commenced a campaign against residential segregation and slum conditions in Chicago, to general sympathy from the mainstream press. Finally, in the last few months before his death in April 1968, King planned the Poor People's Campaign, a massive protest in Washington, D.C., which was intended to obstruct the operation of the federal government nonviolently, unless the government instituted a massive federal anti-poverty program. The mainstream press had misrepresented King's nonviolence as a philosophy of moderation, and assigned King relevance primarily to the South. When King began to emphasise his concerns about poverty in Northern cities and war in Vietnam, the mainstream press depicted these efforts as steps outside King's appropriate purview. The black press, while supportive of King's anti-poverty efforts, expressed similar apprehension about King's anti-war activities. In the first couple of years after Malcolm X's death, however, King remained a popular figure in the mainstream and black press, as they found other radical alternatives to him instead of Malcolm X.

The year after Malcolm X's death, the popularisation of the "Black Power" slogan provided another alternative, against which the mainstream press could place King. Editorialising about the slogan when it appeared in August 1966, the NYT argued that the slogan entailed "nationalism and separatism along racial lines", and compared it to the violence that white Chicagoans had used against King. Associating Black Power

68 'Malcolm X Flees for Life; Muslim Factions at War', NYAN, 20 June 1964, p. 1; 'Home Of Malcolm X Is Fire-Bombed; No Injuries', $C D, 15$ February 1965, p. 3. 
with separatism and violence, the NYT assigned Student Nonviolent Coordinating Committee chairman Stokely Carmichael the same philosophy it had assigned Malcolm X eighteen months earlier. The NYT argued that it was essential that African Americans work within the framework of the American system. ${ }^{69}$ In other editorials, the NYT continued to use King, along with Wilkins, as the responsible alternatives, as it had done when Malcolm X lived. ${ }^{70}$ For the time being, it seemed that, despite King's anti-poverty campaigns in Chicago, the mainstream press were still very sympathetic to King's leadership.

It might seem strange that newspapers were surprised by King's stand. After all, King was a Nobel Peace Prize winner, famed for his strategy of extreme nonviolence, who repeatedly used biblical references about the virtues and necessity of universal Christian brotherhood and love. Further, King had not ignored foreign policy protests prior to his anti-Vietnam War activities. He had, for example, backed a protest against atomic tests as early as 1958 . He had publicly interpreted his Nobel Peace Prize as an award for nonviolence, making specific reference to the threat of nuclear war. ${ }^{71} \mathrm{He}$ had also made public comments about the war as early as the first major military build-up in 1965. It might seem natural that he opposed the Vietnam War so stridently, but the black press viewed the matter differently. Furthermore, by the time King spoke out against the war, most mainstream papers had already expressed serious doubts about it. While not going as far as King's extreme rhetoric in opposing the war, their opposition still might have led them to give a sympathetic hearing to King, especially since they regarded him as a moral authority on so many matters.

The scope rather than the mere fact of King's anti-Vietnam War activities alarmed the mainstream press. King argued that the war distracted from the more important War on Poverty, that it disproportionately resulted in the deaths of black servicemen, that it was the result of "a far deeper malady within the American spirit", which frankly

\footnotetext{
69 'The Politics of Frustration', NYT, 7 August 1966, p. 158.

70 'Black Power Is Black Death', NYT, 7 July 1966, p. 35.

${ }^{71}$ See, for instance, 'Moratorium on Atom Bomb Tests Asked by 140 Protestant Leaders', NYT, 21 April 1958, p. 1; King, Nobel Prize Acceptance Speech, 10 December 1964, http://www.nobelprize.org/nobel_prizes/peace/laureates/1964/king-acceptance_en.html, accessed 21/1/13.
} 
disturbed the mainstream press. ${ }^{72}$ Since they perceived King as a leader particular to the black protest movement, they viewed his opposition to the Vietnam War as an abandonment of his proper role. The NYT's editorial panned King for drawing a "facile" link between the peace and racial equality movements. ${ }^{73}$ The WP went further, dismantling the speech, casting doubts over King's claims about the war, and concluding that his anti-Vietnam War activism had "diminished his usefulness to his cause, to his country and to his people." 74

Black newspapers were aghast that King's opposition for the war had led him to oppose Lyndon Johnson. Johnson's record on civil rights was so impressive that black newspapers discussed him in almost reverential tones when the Voting Rights Act followed the 1964 Civil Rights Act. In March 1965, only fourteen months into Johnson's presidency, the $L A S$, particularly impressed with his record on civil rights, described his achievements as "almost unprecedented". ${ }^{75}$ Upon Johnson's address to Congress on the Voting Rights Bill, now famous for his use of the civil rights movement's 'We Shall Overcome' refrain, his reputation among the editors of black newspapers reached even higher levels. The NYAN gushed adulation for Johnson, naming him "one of the greatest humanitarians of his time", and "one of our greatest Presidents". ${ }^{76}$ The NYAN, in addition to its ardent support for Johnson, considered King's action unpatriotic. ${ }^{77}$

For King to criticise Johnson for his foreign policy seemed a betrayal, to say nothing of political suicide. As the Chicago Defender $(C D)$ observed,

In point of objective reality and in the context of racial justice, he [Johnson] is the greatest President who ever occupied the White House... When the Johnson record of accomplishments is spread before the Negro masses, Dr. King will find few 'soul brothers' who would shout Amen to his plea and join him in a campaign against LBJ. ${ }^{78}$

\footnotetext{
${ }^{72}$ King, 'Beyond Vietnam,' Address delivered to the Clergy and Laymen Concerned about Vietnam, at Riverside Church, 4 April 1967, King Papers Project, http://mlkkpp01.stanford.edu/kingweb/publications/speeches/Beyond_Vietnam.pdf, accessed 26/1/13.

73 'Dr. King's Error', NYT, 7 April 1967, p. 36.

74 'A Tragedy', WP, 6 April 1967, p. A20.

75 'Saluting LBJ', LAS, 21 January 1965, p. A6.

76 'We Are Overcoming', NYAN, 20 March 1965, p. 1.

77 'Where We Stand', NYAN, 15 April 1967, p. 1.

78 'Dr. King's Politics', CD, 24 August 1967, p 17.
} 
In criticising King for opposing the war, the $C D$ made no reference to the war itself. While black editors had not necessarily been keen to offer an opinion on the righteousness of the Johnson administration's policy, they were concerned certainly about the practical wisdom of King's stance. The $L A S$ added that foreign policy remained outside King's proper role. Of King and other black opponents of the war, the paper wrote, "they could devote their time and energy better to helping the cause of their people."79

Black newspapers did not readily take positions on the Vietnam War because they regarded domestic race relations as their primary area of concern. Concerns of foreign policy and international politics had thus never been pressing concerns of black papers, except where they affected the conditions of African Americans themselves. ${ }^{80}$ In the 1950s, for instance, the black press had taken a keen interest in decolonisation in Africa, seeing the process entwined with the movement of African Americans to gain their own freedom. ${ }^{81}$ The Vietnam War was no exception, and King's decision to speak out against the war had therefore represented a step outside the primary domain of the black press. This fear was very much in line with the so-called "moderate wing" of the civil rights movement, represented by figures such as Wilkins and Whitney Young of the Urban League, who were intensely reluctant to take a public stand against the war, for fear of jeopardising the civil rights movement. ${ }^{82}$

Although they had similar views on King's Vietnam stand, the mainstream and black press regarded King's linkage of the war to racism differently. While the WP hinted, upon the first indications from King in 1965 that he opposed the war, that King belonged with civil rights in the South, the NYAN in 1967 argued that "Jim Crow" was behind both racism and the war. ${ }^{83}$ On the other hand, some black newspaper editorials uneasily noted that King's opposition to the war placed him in the company

\footnotetext{
79 'Bedfellows', LAS, 21 December 1967, p. A6.

${ }^{80}$ Charlotte O'Kelly, 'Black Newspapers and the Black Protest Movement: Their Historical Relationship, 1827-1945', Phylon, 43:1 (1 ${ }^{\text {st }}$ Quarter 1982), pp. 1-14.

${ }^{81}$ James Meriwether, Proudly We Can Be Africans: Black Americans and Africa, 1935-1961 (Chapel Hill, 2002), pp. 157-167.

${ }^{82}$ Simon Hall, 'The Response of the Moderate Wing of the Civil Rights Movement to the War in Vietnam', The Historical Journal, 46:3 (September 2003), esp. pp. 669-674.

83 'From Here to Infinity', WP, 14 August 1965, p. A10; 'American Tragedy', NYAN, 6 May 1967, p. 14.
} 
of opponents of civil rights such as Senator William Fulbright. ${ }^{84}$ While the mainstream press repudiated King's connection of Vietnam to racism, the black press could not decide whether such a link was appropriate.

King's Poor People's Campaign attracted much stronger criticism than any of King's previous anti-poverty activism. Describing the proposed campaign as "an appeal to anarchy", the WP accused the organisers of "talking about revolution - even if they call it "passive resistance' or "civil disobedience." "85 For the WP, King's campaign was much closer to home than any campaign he had previously run. The greater scale of King's activities also unnerved the NYT. Sympathetic to King's goals when the protest was initially announced, the newspaper still saw King's aims as unrealistic, and the protest as divisive. ${ }^{86}$ As the protest neared, and King's activities in Memphis sparked violence, the NYT became increasingly convinced that King had made a huge mistake. "[T]here is an inherent contradiction", the newspaper continued, "in Dr. King's summons to Negroes to act 'peacefully but forcefully to cripple the operations of an oppressive society." "87 In doing so, the NYT inadvertently summed up the misunderstanding it, and its mainstream counterparts, had been under about King for more than ten years.

Mainstream newspapers had regarded King's nonviolence as a philosophy of moderation. When King attempted to use nonviolence against the federal government, rather than a local or state administration, it became clear that King did not see nonviolence the same way. It was easier for the newspaper to support King's activities in Chicago, but the demonstration in Washington was more immediate. More importantly, the sheer scope of King's activities had changed. The Chicago campaign, although it was a step outside King's Southern associations, was nevertheless a local one. The Poor People's Campaign was indisputably national, and unlike previous attempts that could be interpreted as seeking negotiation, it aimed to coerce the federal government into a major re-evaluation of its commitment to social justice.

\footnotetext{
84 'Bedfellows', LAS.

85 'King's Camp-In', WP, 26 October 1967, p. A20.

86 'What Do the Negroes Want?', NYT, 19 November 1967, p. 21.

87 'Mini-Riot in Memphis', NYT, 30 March 1968, p. 32.
} 
By the ends of their lives, Malcolm $X$ and King were at crossroads in their professional lives. By 1965 Malcolm X, exhausted from his conflict with his erstwhile friends in the Nation of Islam, struggled to connect with those civil rights leaders, such as King, with whom he had previously disagreed so publicly. He received even less appreciation from much of the mainstream media, whose preoccupation with his stance on violence precluded any chance that they might appreciate his changing worldview. King, by 1968, was fighting to maintain his position as de facto leader of the 'mainstream' civil rights movement. Appearing increasingly unable to direct grassroots protestors, and unpopular among the mainstream political establishment and moderate wing of the civil rights movement, King retained great moral authority, but struggled to maintain his influence as student radicals such as Stokely Carmichael, influenced by Malcolm X, became increasingly prominent.

On 4 April 1968, the morning of King's assassination, the WP described the Washington headquarters of King's Poor People's Campaign. King, of course, was in Memphis at the time, but the article featured interviews with a number of King's followers working on the project. Offhandedly, the WP referred to the early 1960s, when the movement had focused on legally enforced segregation, as the "movement's age of innocence". Such a description may seem curious for a phase of the movement that had involved protestors being beaten, pepper-sprayed, and set upon by dogs and fire hoses. ${ }^{88}$ All the same, the struggle against Jim Crow had, to the mainstream press, involved a level of moral clarity that the three years prior to King's death had lacked. When black protestors fought without violence for the civil rights that the Constitution promised them, against state governments that brutally opposed them on no moral basis, mainstream newspapers could sympathise easily. When those protestors, and King, began to agitate for greater economic rights, placing them in opposition to the federal government, with whom the mainstream press more readily identified, the black protest movement no longer seemed so benign. The WP had no trouble dismissing Malcolm X's leadership upon his death. Upon King's death that evening, the newspaper, like its contemporaries, would be given the opportunity to place King once more within that apparent "age of innocence".

\footnotetext{
${ }^{88}$ Willard Clopton Jr., 'Unity Reigns In Campaign', WP, 4 April 1968, p. C1.
} 


\section{Conclusion}

A close analysis of the mainstream and black press coverage of King and Malcolm X during their lifetimes indicates that media-constructed associations with violence and nonviolence shaped their public images. Clearly, the fear of racial violence pervaded both the mainstream and black press in their discussions of the black protest movement. While King's code of nonviolent resistance was not a philosophy of moderation or gradualism, the mainstream press misread it as such. The black press were generally under no such illusions, but they too were surprised when King began applying his philosophy in relation to the Vietnam War. Though King and Malcolm X represented alternative poles of leadership for the black protest movement, they were never placed on an equal footing in terms of quantity of news coverage. The mainstream press criticised Malcolm $X$ as an anti-white demagogue. Unlike mainstream news coverage, black newspapers generally made no move to denigrate or stigmatise Malcolm X's leadership, although they remained more wary than supportive of his leadership. Newspapers' lack of support for Malcolm X's leadership led them to ignore his evolving worldview as he tried to help the civil rights movement. 


\section{Chapter Two: Mourning to Memory}

On 21 February 1965, as he prepared to speak at a Harlem rally for his new group, the Organization for Afro-American Unity, Malcolm X was gunned down by three assassins associated with the Nation of Islam. Three years later, while visiting Memphis to support striking sanitation workers, King was brought down by a sniper's bullet on 4 April 1968. Both men lost their lives at age thirty-nine. Their assassinations generated considerable media coverage, although Malcolm X's murder did not receive the same level of attention as King's. ${ }^{89}$ Malcolm X's shooting made it to some front pages, but the national media moved on from the event quickly. Despite expectations to the contrary, rioting in Harlem did not materialise. King's death, by contrast, was greatly mourned in official circles and by his followers. President Lyndon Johnson announced a national period of mourning, and the memory of King helped secure support for the Civil Rights Act of 1968. Looting and riots broke out in more than one hundred American cities, an ironic final tribute to a man so dedicated to nonviolent protest.

This chapter examines the newspaper images of King and Malcolm $X$ in the initial years after their deaths, until the establishment of Martin Luther King Day on 2 November 1983. Malcolm X's assassination temporarily reinforced his existing image, while King's led newspapers to focus on what they considered his to be his best work, be it mainstream newspapers' focus of leading the struggle against segregation, or African-American newspapers' image of King as a fighter against all forms of white racism in America. Mainstream newspapers continued to represent King as a moderating influence on the black protest movement, and Malcolm X's ideas as dangerous and counter-productive for the black protest movement. Black protest continued throughout the 1970s, but did not gain the same level of visibility as

\footnotetext{
${ }^{89}$ In examining newspaper responses to the two shootings, it is particularly worth noting the time pressures for the black and mainstream press. The mainstream papers examined were all daily newspapers, publishing seven days a week. The $L A S$ and NYAN published weekly, so they were less up to date every day. Weekly newspapers necessarily focused on recent developments and reflected on the meanings of the assassinations. After Malcolm X's Sunday assassination, the $L A S$ released its first issue the following Thursday. The NYAN had to wait until the Saturday before its next release. Daily newspapers, in contrast, needed to publish the flow of news. Particularly with King, as riots broke out across the nation, their concerns about new violence intensified.
} 
it had in the 1960s. ${ }^{90}$ Newspapers helped establish King as a universally popular figure in the years after his death, leading to his official recognition with a holiday in 1983. By the end of the period, King had become an officially admired and sanctified figure in American politics. For his part, Malcolm X had become a positive leader and role model in the black press, and mainstream newspapers tentatively signalled readiness to re-evaluate his significance.

\section{Assassinations and their aftermaths}

Despite the many differences in the public images of both King and Malcolm X, their assassinations gained more press coverage than anything they did during their lifetimes. In the week following his murder, the New York Times (NYT) mentioned King in over 300 articles. By contrast, in the week following the 1963 March on Washington, the supposed high point in King's public career, the $N Y T$ mentioned King in only thirteen articles. Malcolm X's violent death also received attention unlike any he had received previously. However, newspapers characterised each assassination differently, something noticeable even in the photographs printed. The NYT, Washington Post (WP), and the Los Angeles Time (LAT) all carried pictures of a dying Malcolm X being rushed to hospital. Conversely, after King's assassination all three published pictures of a living King on their front pages, implicitly endorsing the significance of his life, and reflecting an idea that Malcolm $\mathrm{X}$ had lived advocating violence and died by the same means. ${ }^{91}$

In addition to the sheer volume of coverage that the assassinations generated, these events also marked the transition between King and Malcolm X as living, active participants in the news, and historical figures interpreted and accorded significance by others. After their deaths, stories about King and Malcolm X became detached from current activities. The actions of others, relating to King and Malcolm X, often constituted the news - whether a review of Malcolm X's autobiography, an event attended by a member of the King family, or celebrations of either King or Malcolm

\footnotetext{
${ }^{90}$ Stephen Tuck, "“We Are Taking up Where the Movement of the 1960s Left off”: The Proliferation and Power of African American Protest during the 1970s', Journal of Contermporary History, 43:4 (October 2008), pp. 637-654.

${ }^{91} L A T, 22$ February 1965, p. 1; NYT, 22 February 1965, p. 1; WP, 22 February 1965, p. 1; $L A T, 5$ April 1968, p. 1; NYT, 5 April 1968, p. 1; WP, 5 April 1968, p. A1.
} 
X's birthday. Coverage of their deaths provided the first interpretations of the lives of King and Malcolm X and influenced their public memory of King and Malcolm X as it evolved over the decades from their deaths.

Hardly a shot heard around the world, the press generally did not regret Malcolm X's death for the loss of Malcolm X's leadership as for the violence that took Malcolm X's life. For the black press, it was particularly significant that Malcolm X's assassins were black, which caused them to lament the fact that African American activists were killing one another instead of seeking unity. The mainstream news media granted Malcolm X's murder limited significance consistent with their coverage of him during his lifetime. While he lived, there were few occasions when the LAT, NYT, and WP's front pages covered the same story on him. His violent death proved newsworthy, although the assassination still competed with other news stories for prominence on the front page. All three made the assassination a front-page story, describing in detail the murder, and accompanied stories with photographs from the murder scene. ${ }^{92}$

Malcolm X's death was regarded as newsworthy because of the violence that took his life, and not because the media deemed his death to be a significant loss to the black protest movement. In the immediate aftermath, mainstream newspapers reflected unsympathetically on his death's significance. The title of the WP's editorial on the assassination was 'Assassination', rather than something relating to Malcolm X himself, indicating that their primary concerns lay not in the loss of Malcolm $\mathrm{X}$ himself but in his violent death. The paper focused on the violence of assassination, finding "not much in the career of the murdered man to comfort his country." 93 In an earlier, more extensive, article discussing Malcolm X's life, it appeared uninterested in Malcolm X's worldview. The paper quoted only Malcolm X's comment about the assassination of John F. Kennedy as an explanation of his split with the Nation hardly a favourable comparison. Describing the fallout from their split, the paper asserted Malcolm X's "ideas did not change and he continued his work as a Black

\footnotetext{
${ }^{92}$ LAT, 22 February 1965, p. 1; NYT, 22 February 1965, p. 1; WP, 22 February 1965, p. 1.

93 'Assassination', WP, 23 February 1965, p. A16.
} 
Nationalist evangelist with unremitting vigor." 94 The paper, typical of the mainstream press, equated black nationalism with black separatism and black supremacy.

Like the WP, the NYT reflected unsympathetically on Malcolm X, but as he was a more local figure, they gave the assassination more prominence than the WP. Regarding Malcolm X's life as a cautionary tale against the dangers of radicalism and violence, the paper dismissed his contribution to the black protest movement. "The world he saw through those horn-rimmed glasses of his was distorted and dark", the $N Y T$ editorialised. "But he made it darker still with his exaltation of fanaticism." 95 To the NYT as to the WP, Malcolm X's death was lamentable because of the violence that he advocated and that ended his life, and not because the black protest movement had lost an important leader. The article described both the Nation and Malcolm X himself as "militant", not a term the paper tended to use as a compliment, and continued to offer only Malcolm X's remark about the Kennedy assassination as a reason behind the split. ${ }^{96}$ The paper also published an article detailing the arrest of one of the assassins, Thomas Hagan, who had to be rescued from a crowd of Malcolm X's supporters. The article quoted a police officer claiming that Hagan would have been killed by the crowd had it not been for the police intervention, hinting that Malcolm $\mathrm{X}$ 's followers were also violent. ${ }^{97}$

The NYT's coverage of Malcolm X's death, like that of the WP, reflected the paper's negligence toward his ideology. Throughout his life, the NYT, associating Malcolm X with radicalism, violence, and black supremacy, had portrayed his criminal career in Boston and New York as black marks against his character, rather than early chapters in an inspiring story of self-transformation. Although the NYT eventually revised its disdain for his criminal past, throughout 1965 it remained unimpressed by Malcolm X's prison conversion. The NYT's lack of interest in Malcolm X extended even to his family life, as one of his four daughters, a three-year old named Ilyasah, was mistaken for a two-year old son. ${ }^{98}$ The paper also invited scepticism about Malcolm X's explanation for his father's death and his name change: "He believed his father... was

\footnotetext{
${ }^{94}$ Ramon Geromia, 'Victim Known as Articulate Leader', WP, 22 February 1965, p. A3.

95 'Malcolm X', NYT, 22 February 1965, p. 20.

96 'Malcolm X Shot to Death at Rally Here', NYT, 22 February 1965, p. 1.

${ }^{97}$ Gay Talese, 'Police Save Suspect From the Crowd', NYT, 22 February 1965, p. 10.

${ }^{98}$ Peter Kihss, 'Malcolm X Shot to Death at Rally Here', NYT, 22 February 1965, p. 1.
} 
murdered. [...] He became known as Malcolm X, because he was sure that his family name of Little 'had been taken from former white masters." 99 The paper, like much of the mainstream press during Malcolm X's life and immediately after it, distanced itself from such claims in a manner that it did not use with figures of whom it approved or to whom it deferred.
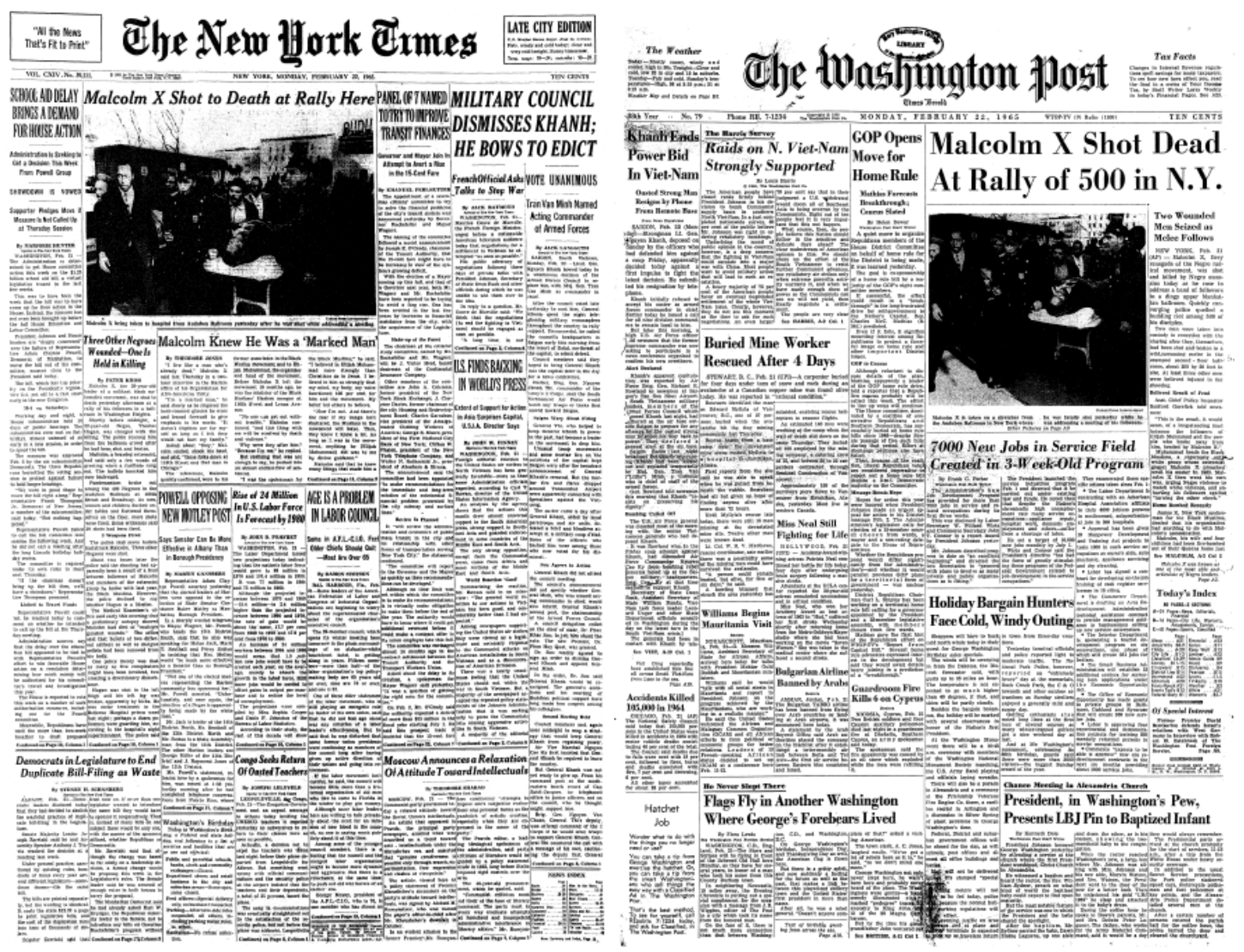

Figure 2.1 - the pictures accompanying the NYT and WP's stories on Malcolm $X$ 's death illustrate their main concern: the violence that ended Malcolm X's life. Note also the relative lack of space the story receives, compared with other news events.

Like the mainstream press, most black papers took a negative attitude regarding Malcolm X's assassination. The Los Angeles Sentinel (LAS), for instance, gave the death of Malcolm X less coverage on the front page than the Los Angeles funeral of Nat King Cole held a week earlier, King's presence in Los Angeles, and the bizarre story of a local television repairman murdered in a dispute with his wife, apparently regarding a hot dog, the previous weekend. ${ }^{100}$ The week after King's death, by

\footnotetext{
99 'Malcolm X', NYT. Emphasis added.

${ }^{100}$ LAS, 25 February 1965, p. A1.
} 
contrast, the $L A S$ published "A Special Memorial Edition" to King, with a photo of King taking up most of the front page. The New York Amsterdam News (NYAN), reflecting Malcolm X's local significance, allowed its coverage of the event to dominate its front page. Neither the LAS nor the Chicago Defender $(C D)$ gave any extensive reflection at this point on Malcolm X's significance to the movement, concerning themselves instead with the violence surrounding his end. ${ }^{101}$ The sense of loss that would characterise their tributes to King upon his death was largely absent when Malcolm X lost his life, with one exception.
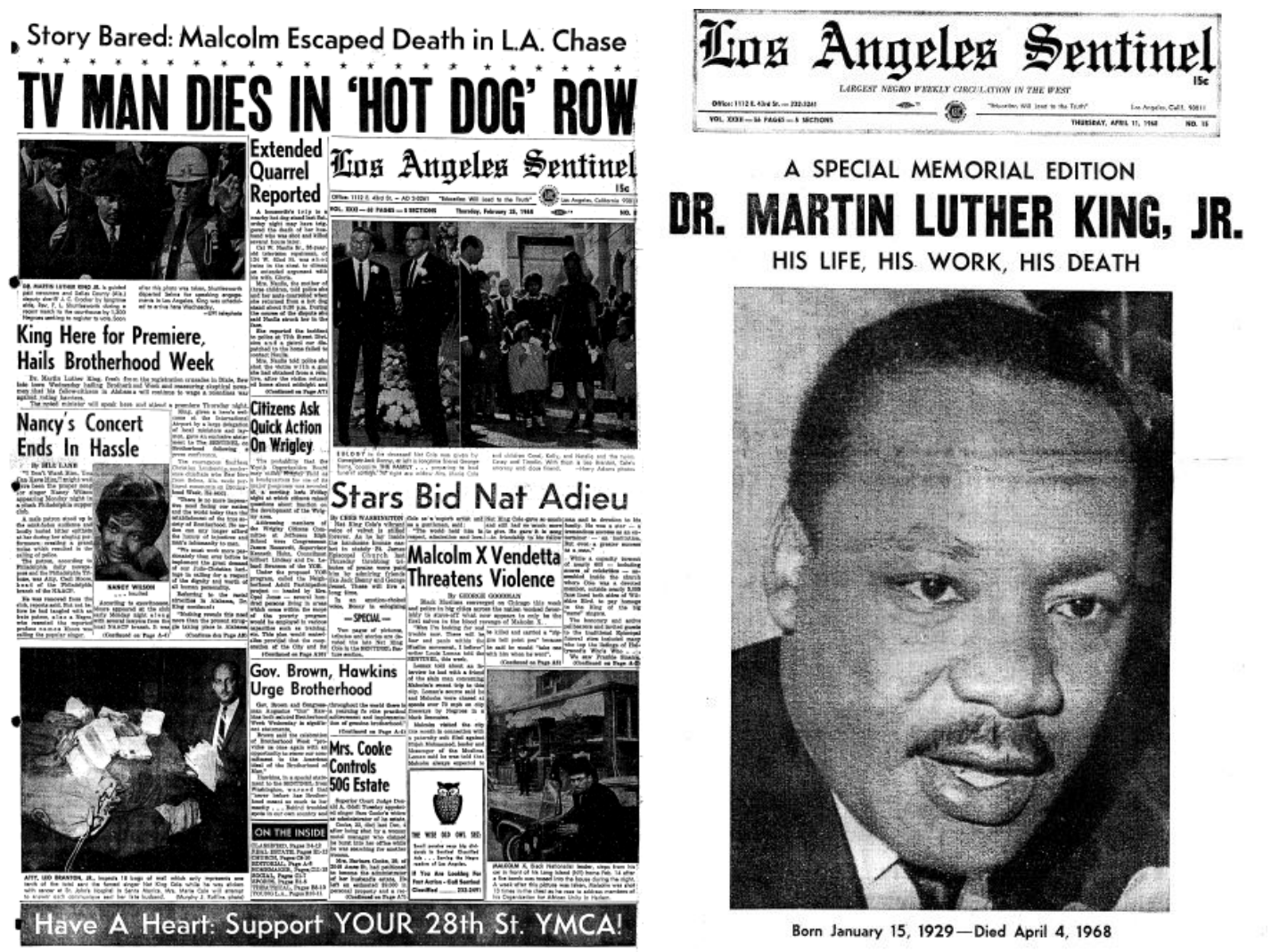

Figure 2.2 - the $L A S$, like much of the black press, took a similar stance to mainstream newspapers on the death of Malcolm X. The newspaper gave the death scant attention on the front page (bottom right-hand corner), and emphasised the possibility of violence ahead. By contrast, the $L A S$ devoted a whole issue to King after his assassination, focusing not just on King's death, but also his lifetime and his achievements.

In contrast to other newspapers, the NYAN stressed Malcolm X's value to the black protest movement. To the NYAN, his importance derived mainly from his existence as a menacing alternative to King's side of the movement. All the same, the paper

101 'Malcolm X Killed At N. Y. Meeting', CD, 22 February 1965, p. 1; George Goodman, 'Malcolm X Vendetta Threatens Violence', LAS, 25 February 1965, p. A1. 
acknowledged the unease with which many African Americans regarded him: "he was almost a black savior and while there were few who would publicly admit any respect or friendship for him... Malcolm's place in history is assured - for better or worse." 102 Hardly a ringing endorsement, but unlike its contemporaries the NYAN at least was prepared to grant Malcolm X significance. As the major black newspaper in New York, the NYAN undoubtedly understood that he had a significant following in the community where its readers were concentrated.

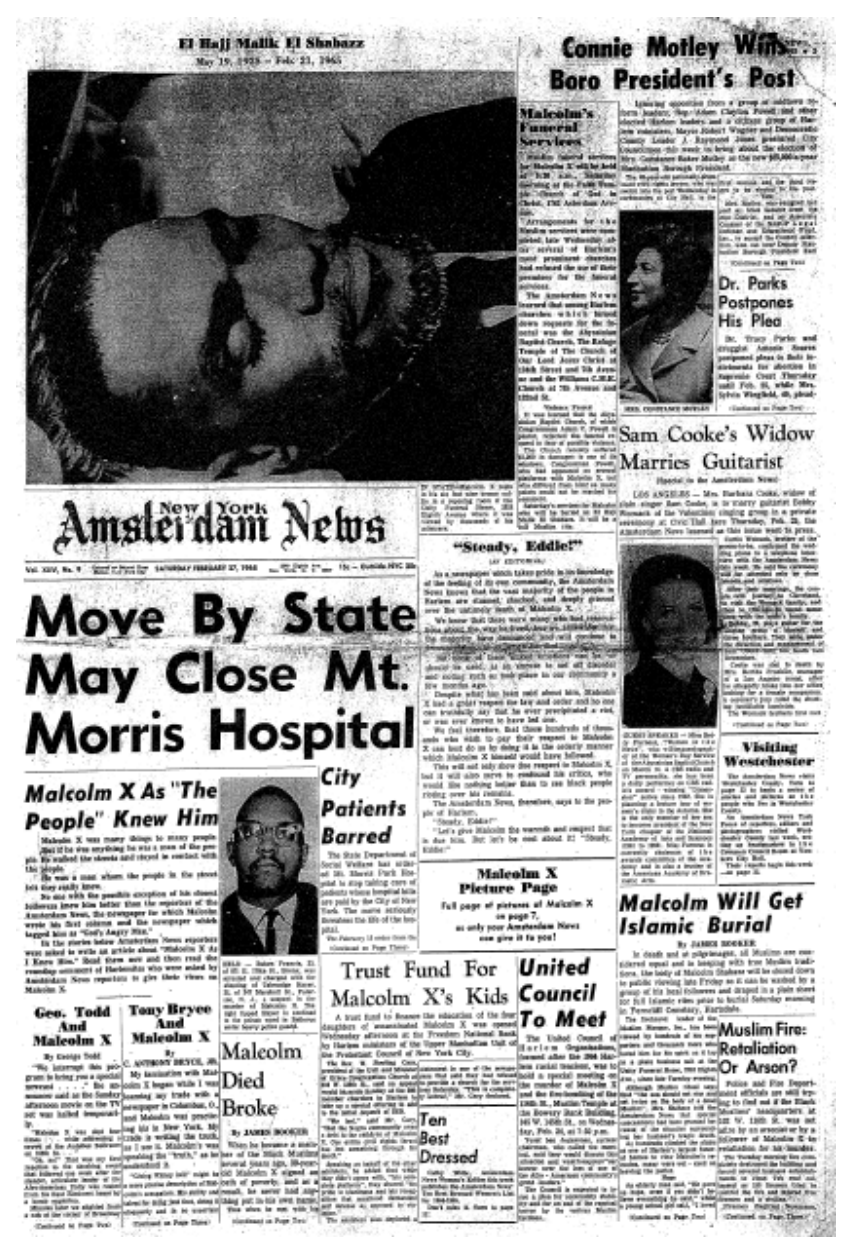

Figure 2. 3 - with a large picture of Malcolm X's body lying 'in state', and several articles dedicated to his lifetime and significance to his followers, the NYAN was the only newspaper studied that conveyed any sense of loss after Malcolm X's death.

The NYAN's appreciation for Malcolm X did not stop it from associating him with violence, but the paper moved beyond such associations in evaluating Malcolm X's life. After his assassination as in the last year of Malcolm X's life, the threats of

102 'Someone Said ...', NYAN, 13 March 1965, p. 10. 
violence exchanged between the Nation and Malcolm X's supporters remained prominent in its coverage, and his evolving views on race did not receive particular attention. The paper still communicated a sense of loss with Malcolm X's death. ${ }^{103}$ In a front-page editorial, in marked contrast to the NYT, the NYAN even used Malcolm X to exhort its readers against violence. "Despite what has been said about him," the paper argued, "Malcolm X had a great respect for law and order and no one can truthfully say that he ever precipitated a riot, or was ever known to have led one."104 The editorial indicated the tone of the paper's coverage of the event. It acknowledged that there would be readers who were less than enthusiastic about Malcolm X, but unlike other papers it conveyed respect for Malcolm X at the same time it expressed distaste for violence. In using Malcolm $X$ to oppose violence, the newspaper demonstrated that it could find something more in Malcolm $\mathrm{X}$ than his aggressive rhetoric, and provided its readers with a more nuanced portrait than the onedimensional image presented in much of the media.

The NYAN was not alone in lamenting King's assassination in April 1968. Although the mainstream and black press presented him as a man whose best work was behind him, on the eve of his assassination King retained considerable moral authority. All newspapers regarded King's murder as hugely significant, and expressed a sense of loss at his death. The black papers published in the month after King's murder focused on King's life and achievements, and little else. Mainstream papers, published on a tighter deadline the day after the assassination, also paid considerable attention to King, informing readers about other news, such as the ongoing presidential primaries and the situation in Vietnam. Their response to King's assassination was also marked by opposition to violence, but the coverage afforded King's life and the loss of King to the movement were just as important. The depiction of this tragic loss was similar in the black and the mainstream press, but there were some subtle differences, as the black press regarded King's loss as particularly calamitous for the African-American community, which still needed his inspirational leadership.

103 “"Steady, Eddie!”, NYAN, 27 February 1965, p. 1.

${ }^{104}$ Ibid. 

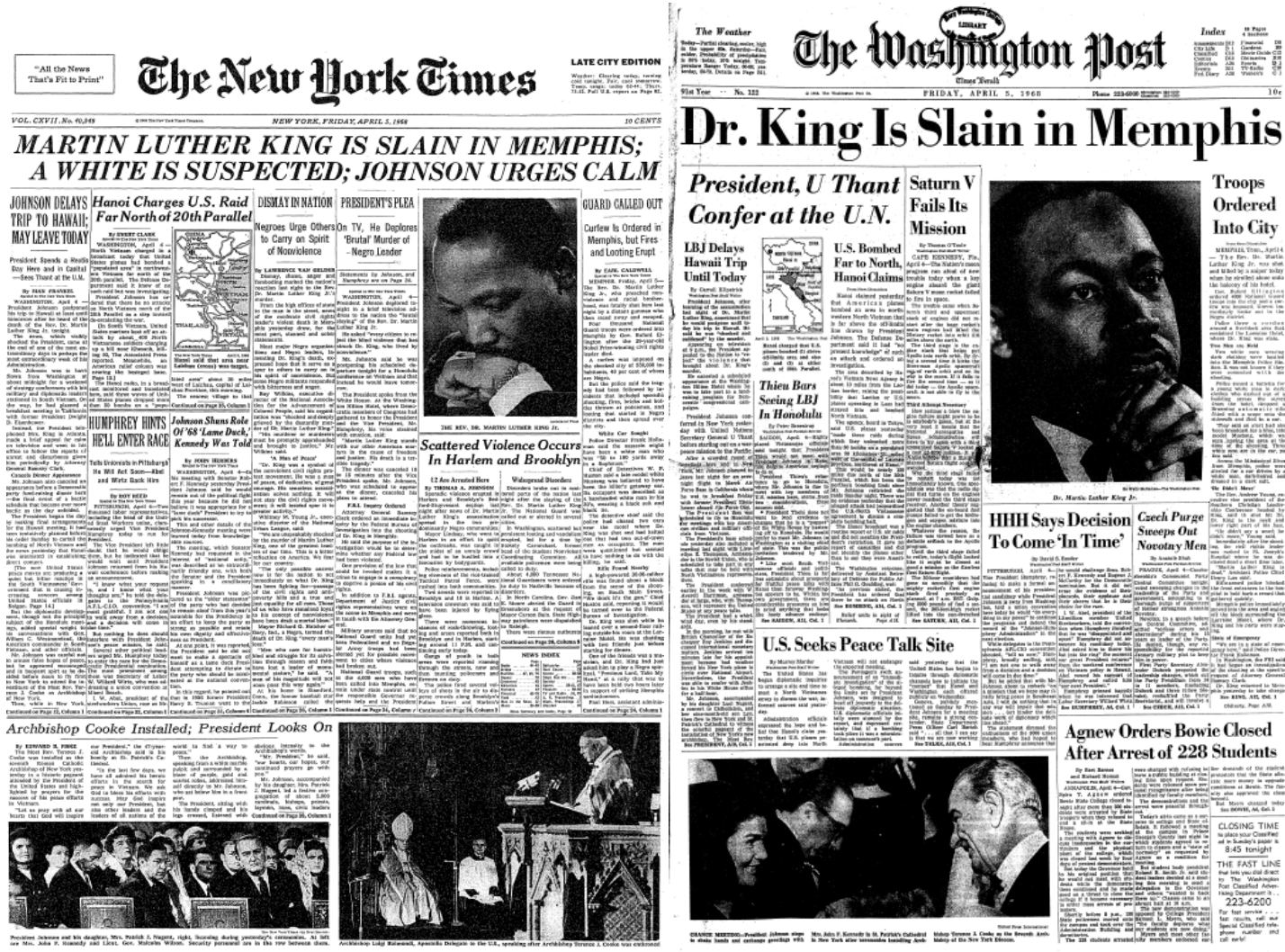

Figure 2.4 - in contrast to their response after Malcolm X's death, mainstream newspapers like the NYT and WP conveyed a sense of lost leadership upon

King's death, publishing a number of obituaries as well as pictures of a living, rather than dying, King.

The mainstream press represented King as a moderating influence on the black protest movement. One NYT article subtitle remembered King as a 'Nobel Winner... Attacked by Both Negro Militants and White Extremists', implying that he occupied both the moral high ground and the pragmatic middle ground where racial reconciliation could occur. ${ }^{105}$ King's leadership had been valuable to all Americans, in part because of his "restraint", a quality the newspaper had admired in King from the moment he emerged on the national scene. To the NYT as to the mainstream media, King's death was a loss for all Americans, regardless of race. It wrote that King's death had "torn into the fiber of every American of every race, color and creed."106 The LAT emphasised King's commitment to nonviolence in its reporting of the slaying, and its editorial pages stressed King's role as a bridge between the races. Concerned that King's death might lead to the racial catastrophe they had predicted

\footnotetext{
${ }^{105}$ Murray Schumach, 'Martin Luther King Jr.: Leader of Millions in Nonviolent Drive for Racial Justice', $N Y T, 5$ April 1968, p. 28.

106 “"The Need of All Humanity”, NYT, 5 April 1968, p. 46.
} 
should King's approach fail, the mainstream media depicted King as a unifying figure, whose leadership forestalled such developments during his lifetime. ${ }^{107}$

Mainstream newspapers quickly positioned King in the civil rights movement in the South up until 1965, focusing on the well-known events, particularly his address to the 1963 March on Washington. Some of the references to the speech were subtle, repeatedly using the word "dream" in reference to King, alluding to his address to the March on Washington in 1963. Many pieces made explicit, often lengthy, references to the speech. King's more recent and controversial actions - urban marches in Chicago, anti-war protests, and the Poor People's Movement and its planned encampment in Washington, D.C. - received less emphasis in a portrait intended to present him as a conciliatory figure bridging the widening social divisions exposed in the violence following his death. One feature dedicated to King in the WP not only began by quoting the "I have a dream" section of the speech, but completely omitted any mention of activity from mid-1965, ending with King's insistence during the 1963 Birmingham campaign on "Forgiv[ing] our white brothers". ${ }^{108}$ The mainstream press imbued King with the prophetic qualities of an Old Testament hero, as a WP editorial began, "To each generation of mankind is given one or two rare spirits, touched by some divinity, who see visions and dream dreams." 109 The newspaper characterised King as a Christlike figure, "given" to humanity by God and whose death had offered a form of redemption for the American people, rather than an imperfect and human leader.

While the mainstream press sanctified King and raised him up above the racial divide, the black press focused on his leadership of African Americans, a focus that involved being perhaps swifter than the mainstream press in ignoring inconvenient aspects of King's worldview. This focus tied not just to notions of racial pride, but also to masculinity, in an echo of the "I Am a Man" signs carried by the Memphis union members King had gone to help. The NYAN's editorial commemorating King declared,

107 Nicholas C. Chriss \& Jack Nelson, 'Dr. King Slain by Sniper in Memphis', LAT, 5 April 1968, p. 1; 'Assassination of Dr. King', LAT, 7 April 1968, p. K4; 'A Crossroads in U.S. History', LAT, 7 April 1968, p. K6.

108 'Dr. King, Apostle of Nonviolence, Drew World Acclaim', WP, 5 April 1968, p. A12.

109 'Martin Luther King Jr.', WP, 6 April 1968, p. A12. 
Dr. Martin Luther King, Jr., was a MAN. Also MEN are the 1,300 sanitation workers in Memphis on whose behalf he was in the city last week when he was so grievously struck down. Not so the assassin who fired the shot... Neither are all those MEN who now hypocritically raise their pious voices to eulogize a man they were damning both publicly and privately weeks earlier. ${ }^{110}$

The paper did not state it, but it may have remembered that it had never regarded King as above suspicion during his lifetime. NYAN editorials on King's Vietnam stand, as the first chapter discussed, had expressed great unease as to the wisdom of his move, although they had never let this affect their support for King's leadership of the rest of the movement. While mainstream newspapers de-emphasised King's opposition to Vietnam, the black press almost completely drowned out any issues not in keeping with the concerns of the African-American community.

The black press turned King into a political symbol immediately after his death. The NYAN used the assassination to advocate racial integration. Its coverage of King's funeral carried the headline, 'Black, White, Came to Bury Martin Luther King, Jr.'111 Although it published similar articles, the $L A S$ also underscored the areas they considered most important, particularly in favour of economic integration. ${ }^{112}$ Unlike the major dailies, which suggested that radical elements in the black liberation movement had marginalised King, black papers insisted on King's continued relevance. The depiction of King as a figure in touch with the concerns of the most disadvantaged African Americans also provided the opportunity for a greater sense of convergence between him and Malcolm X, although this opportunity was not taken yet.

Unlike the mainstream press, the black press used King's memory as a prod or justification for greater anti-poverty progress. While some mainstream newspapers, like the $N Y T$, sympathised with such concerns, they did not use King explicitly for such causes immediately after his death. While mainstream newspapers lamented King's passing and remained somewhat vague about what goals King's memory

\footnotetext{
110 'He Was a MAN', NYAN, 13 April 1968, p. 20. Emphasis in original.

${ }^{111}$ Cathy Aldridge, 'Black, White Came to Bury Martin Luther King, Jr.', NYAN, 13 April 1968, p. 1.

${ }^{112}$ Bill Lane, "I Have Discovered That The Highest Good Is Love”', LAS, 11 April 1968, p. A5.
} 
could serve, the NYAN insisted in its editorial pages that to serve King's memory "America must... create a climate of economic and social equality for all."113 A fortnight after King's death, the $L A S$ minimised the significance of the recently passed 1968 Civil Rights Act, and used the riots to demand "massive sums for education, job training, slum clearance and replacement programs, and adequate - we repeat, ADEQUATE - social welfare and health programs". ${ }^{114}$ In doing so, the black press continued to emphasise social justice, in keeping with their usual concerns not prioritised by major newspapers. ${ }^{115}$ The African-American newspapers, like their mainstream counterparts, represented King so that he appeared to be as close to them politically as possible. Black newspapers ignored his anti-war activism, and portrayed the breadth of his appeal only in terms of its value to readers of African-American newspapers.

\section{"The path of reason"?}

Once the period of mourning for King ended, the commemoration of his life began. Meanwhile, African Americans also began to commemorate the birthday of Malcolm $\mathrm{X}$. Malcolm X retained prominence for a few years as student militants cited him as an influence. Broadly speaking, however, Malcolm X's afterlife was at first less public than King's, as the black community lobbied persistently for King's birthday to be a national holiday. Ultimately, this produced the Martin Luther King, Jr., Federal holiday in 1983, and then in 2011 the dedication of the King Memorial on the National Mall of Washington, D.C. These developments allowed Malcolm X to augment King as a hero for the black protest movement.

At the beginning of 1969 there was little reason for the editorial board of the NYAN to be optimistic. It was the final year of a decade that had promised much by way of racial reform and progress, a decade that began with the rise of sit-ins, greater visibility for the concerns of African Americans, and with the black vote being apparently decisive in determining a presidential election. Despite the achievements of the black protest movement since 1956, by 1969 many in the movement felt their

\footnotetext{
113 'After the Eulogies', NYAN, 20 April 1968, p. 16.

114 'Time for Realism', LAS, 18 April 1968, p. A6. Emphasis in original.

${ }^{115}$ Charlotte O'Kelly, 'Black Newspapers and the Black Protest Movement, 1946-1972', Phylon, 41:4 (4 ${ }^{\text {th }}$ Quarter 1980), pp. 313-324.
} 
social and economic goals had yet to be reached. The outlook was not promising, and not just because of King's assassination. The liberal Democratic coalition, in which the moderate black leadership had invested so much political capital, was torn by infighting and another Kennedy assassination, and swept aside by Richard Nixon's presidential campaign and the so-called "silent majority" the previous year. With Nixon's strident calls for law and order, the new political climate appeared unpromising, but the NYAN still tried to find some source of hope, and a strategy for progress.

Wondering how African Americans might achieve progress in such an unfavourable environment, the NYAN observed that there appeared to be two paths from which to choose: separatism and integrationism. While sympathetic to the demands of black nationalists who questioned the success of over a decade purportedly aimed at "integration", the NYAN still could not - or would not - go beyond the conviction that the best hope of African Americans lay with the "American system", arguing, "If it is idle to dwell on the unrealistic heights of absolute integration, it is self destruction to plumb the depths of black separatism. Our path must be the path of reason lying between." The editorial named Malcolm X, along with the still-living Stokely Carmichael, as black separatists, while it claimed King, as well as Thurgood Marshall, the former attorney for the NAACP recently appointed to the Supreme Court, as symbols of "accommodation". ${ }^{116}$ Though this dichotomy was not new, and the paper at this point gave no sense that either Malcolm X or King went beyond their respective spheres, it presaged an important aspect of King and Malcolm X's posthumous images in newspapers by setting the pair up as apparent alternatives, and arguing that African Americans did not have to choose either one exclusively.

In early 1969 newspaper articles mentioning King, in both the black and mainstream press, focused on four overlapping categories: news events pertaining to schools, hospitals, or some other club or institution named after him; public events held in his honour, particularly on his birthday; the movement to make his birthday a federal holiday; and finally the revelations surrounding the Federal Bureau of Investigation's pursuit of King during his lifetime. Public events on King and Malcolm X's birthdays

116 ‘The Path Of Reason', NYAN, 4 January 1969, p. 1. 
became annual occurrences over the 1970s, particularly for the black community. They were reported in the mainstream and black press, although more prominently in the black press. Black newspapers in particular covered the King events in the context of the movement to create a federal holiday in King's name. Since there was no significant movement to commemorate him similarly, Malcolm X's birthday became an occasion for celebration largely for the African-American community.

Malcolm X maintained a measure of prominence from around 1968 until the early 1970s, particularly among student activists. To the mainstream press, the actions of the students who used Malcolm X were more important than Malcolm X himself. Malcolm X was usually described as a "black nationalist", and while the newspapers did not ascribe violence to Malcolm $X$ himself, they did use it indirectly by associating it with Malcolm X's disciples. The NYT described him as a proponent of "militant black separatism". The WP referred to him as a "firebrand", associating him with the ascendant Black Power movement. ${ }^{117}$ Malcolm X became associated with student militancy. While this association meant that Malcolm X received a steady number of mentions for a few years, Malcolm X's prominence in the press declined as the students' protest movements dwindled. Articles about Malcolm X also tended to focus on public events commemorating him. Like King, Malcolm X's birthday in May became an annual event for some African Americans, although it does not seem to have been commemorated much until after King's assassination.

King's birthday, along with growing official recognition of King, provided opportunities for newspapers to write about King. Newspapers did not always take the chance to convey King's importance explicitly. In 1974, Georgia Governor Jimmy Carter commissioned a portrait of King to hang outside the governor's office as part of his plan to give greater recognition to Georgia's black community. The NYT covered the story approvingly, but did not detail what made King worthy of such an honour. ${ }^{118}$ Similarly, in that year's observation of King's birthday, the WP gave extensive coverage to the activities dedicated to King, but did not dwell on King's life

\footnotetext{
117 'Student Walkouts Honor Malcolm X', WP, 22 February 1969, p. A3; James T. Wooten, 'Malcolm X University to Open In Durham as Militants' School', NYT, 28 October 1969, p. 44.

${ }^{118}$ B. Drummond Ayres Jr., 'Georgia to Hang Dr. King Portrait', NYT, 5 January 1974, p. 25.
} 
or what made King so important. ${ }^{119}$ Black newspapers were often similar, as many of their articles relating to King did little to evaluate or comment on his significance, but they usually compensated with an editorial on King himself.

Scholars often spotlight the success of The Autobiography of Malcolm X, published in 1965, as the major factor in its subject's posthumous renaissance, although mainstream newspaper coverage indicates that this revival was not immediate. The WP did not publish a review of the book until December 1969, when the book was in its eighteenth printing. ${ }^{120}$ Other newspapers reviewed it, but even then there it was not clear that they might re-evaluate Malcolm X years later. The NYT called the book "extraordinary" and tentatively ascribed Malcolm X importance to the black protest movement, but focused more on Malcolm X's childhood and youth, implying the paper was more concerned at the social conditions that might produce the next black nationalists. ${ }^{121}$ The $L A T$ 's reviewer was much less sympathetic, writing that the book portrayed Malcolm X as "demagogic, opinionated, hypocritical, opportunistic, and... either ignorant or deliberately blind to the facts of history." ${ }^{122}$ From the mid-1970s until the eventual establishment of the King holiday, mainstream newspapers gave Malcolm X much less attention than King. For a ten-year period beginning in 1974, the NYT mentioned Malcolm X in no more than thirty-seven articles in a single year. Over the same period, the same paper consistently mentioned King in over 200 articles every year. The same trend was even more pronounced in the $W P$, where articles mentioning King outnumbered those mentioning Malcolm X by about eight to one (see figure 2.1).

\footnotetext{
${ }^{119}$ Adam Shaw, 'Many in City Note Dr. King Birthday', WP, 16 January 1974, p. C1.

${ }^{120}$ Nicholas von Hoffman, 'Malcolm Lives', WP, 1 December 1969, p. C1.

${ }^{121}$ Eliot Fremont-Smith, 'An Eloquent Testament', NYT, 5 November 1965, p. 35.

${ }^{122}$ Robert Kirsch, 'The Real and Imagined Faces of Malcolm X', LAT, 5 November 1965, p. C6.
} 


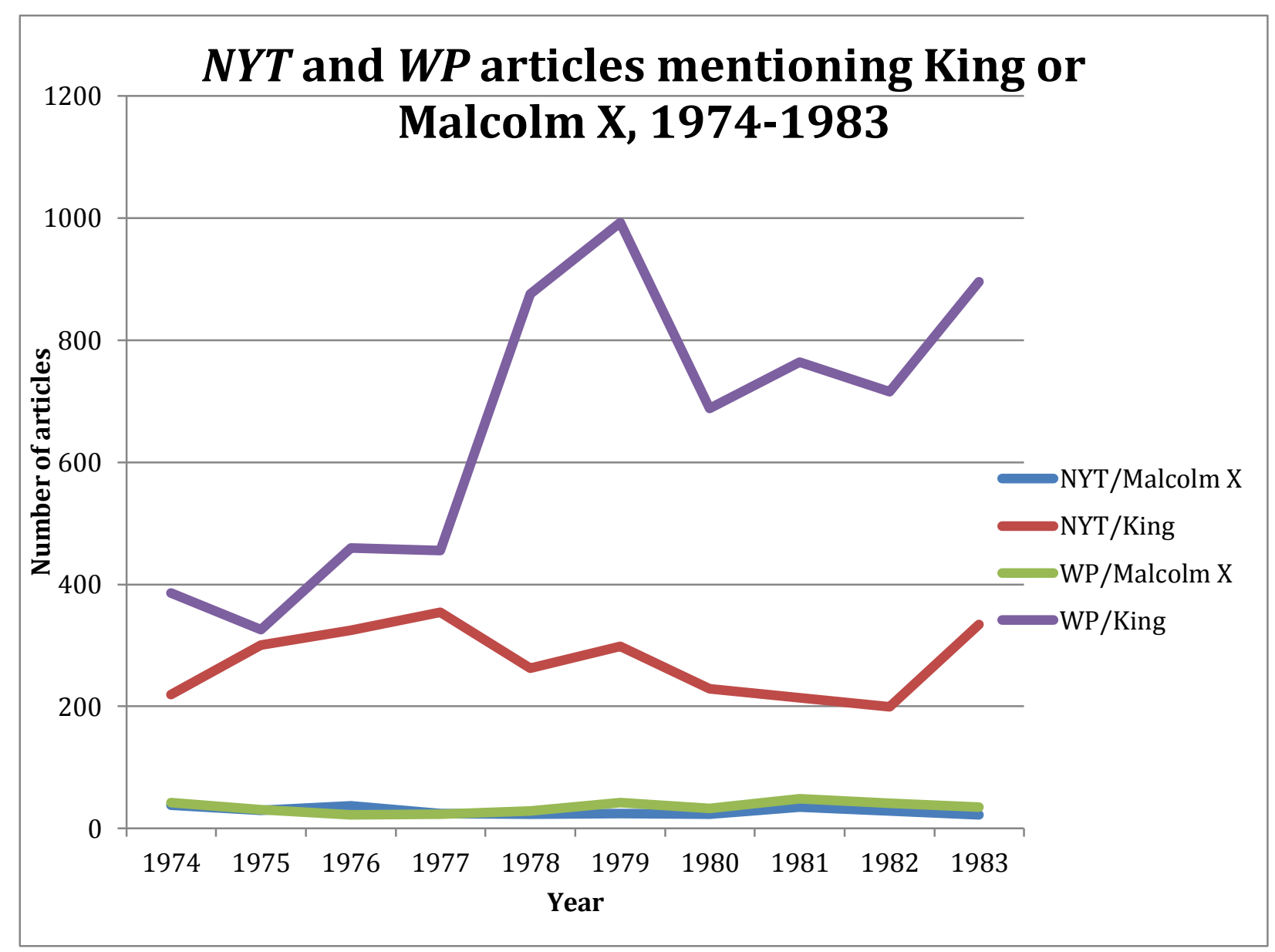

Figure 2.5

Black newspapers in particular marked the anniversary of King's death, usually focusing on their sense of loss of King's leadership. These stories usually began by imagining if King were still alive. Black papers, unlike mainstream papers, considered what King's leadership would bring to the black community, were he still alive. Mainstream papers, however, were more likely to praise King's life itself, as well as declare support for their interpretation of King's agenda - an interpretation based on racial reconciliation. Not only did time ease the pain of King's passing, but King's birthday became so popular that it was almost a de facto holiday for the black community.

After an initial focus on racial reconciliation, as the 1970s progressed black newspapers began to emphasise the lack of formal recognition given to African Americans. Summarising the feelings of many in the African-American community, the LAS noted, "most of our present holidays glorify wars, generals and personages 
which have nothing to do with America of black people [sic]." ${ }^{123}$ The officially sanctioned culture of remembrance ignored the contributions of African Americans. By the late 1970s, African Americans increasingly felt that they had been marginalised by the political establishment, and that many of their gains from the 1960s were eroding. As overt racial tension declined, African Americans remained largely absent from positions of power. If the federal government needed to recognise an African American, King was an ideal candidate as he was so popular with both white and black Americans.

For the black press, the value of a national King holiday lay in his significance for African Americans, which they emphasised over his wider appeal. Editorials in favour of a King holiday characterised him as a Moses-like figure unique in American history, whose actions had led African Americans toward a more just existence in the United States. While it appreciated and supported white opinion leaders who argued along the lines of King as an ecumenical figure, King became a primarily black figure when the $L A S$ put the case in its own words. Earlier editorials argued that King could represent all Americans and become a symbol for all citizens. The $L A S$, in making an early call for the holiday in 1971, quoted the senators who introduced a bill to establish such legislation, arguing that King "called all Americans to a higher standard of brotherhood and love." 124 Black newspapers initially supported this line without actively adopting it, but de-emphasised it as the 1980s approached, reflecting increasing frustration among the black press with the lack of urgency on racial equality shown by the predominantly white federal government.

The black press also agreed a holiday, rather than a statue, was a more appropriate way of commemorating King. Academic William Seraile, writing in the NYAN, summed up the main concern: "unless constantly informed people, especially children, would not know about the statue's existence." ${ }^{125}$ A holiday in King's honour ensured an annual remembrance to help perpetuate his message. The LAS expressed similar hopes in honouring King. "The people of this nation should be reminded each year... that racial bias and the concept of white supremacy killed the greatest leader

123 'King Holiday', LAS, 11 January 1973, p. A6.

124 'A National Holiday for MLK', LAS, 8 April 1971, p. A6. Emphasis added.

${ }^{125}$ William Seraile, 'Hypocrisy of New York Times', NYAN, 25 December 1982, p. 13. 
this community has ever known." To the LAS, Martin Luther King Day would not even have to be a holiday, it simply had to remind people of King, further suggesting that schoolchildren be required to produce "a commemorative essay" on King. ${ }^{126}$

\section{$\underline{\text { Resignation, Reagan and reaction }}$}

Having supported a synthesis of black nationalism and integrationism in 1969, the NYAN's faith in the American "system" did not last. By 1978, the paper abandoned its so-called "path of reason" in favour of a philosophy of black nationalism. While in 1969 there had still been some reason to expect progress, a period of retrenchment and apathy on the part of the establishment had removed much of that optimism. So great was the NYAN's disappointment that it even wondered if they had reached 'The end of Dr. King's dream'. ${ }^{127}$ The NYAN's stance reflected the changing attitude of the black community regarding integration, which depended for its success on the sympathy with the white community. As this sympathy diminished during the 1970s, so did the popularity of integration. The NYAN's disappointment with the white community increased with Ronald Reagan's election as president in November 1980, but despite a seemingly unsympathetic president, the campaign for a King holiday finally achieved its goal. At the same time, this disillusion opened the way for greater attention to Malcolm X, who had never expected the American system to deliver full equality, and who in any case was unlikely to be appropriated by the white establishment.

The advent of the Reagan administration proved to be an apprehensive time for African Americans. Although some conservative black newspapers, such as the $A D W$, endorsed Reagan's candidacy, other African-American editors deplored his victory. ${ }^{128}$ Ahead of Reagan's first inauguration, the LAS prophesied that his presidency might signal "a new low in race relations". ${ }^{129}$ Once Reagan was in office, black newspapers saw little in his administration to assuage their fears. A year in, the NYAN accused Reagan of being the worst president for race relations in sixty years, claiming that "not since Woodrow Wilson has there been an American President so content with an

\footnotetext{
126 'A Shrine for a Hero', LAS, 5 April 1976, p. A6.

127 'The end of Dr. King's dream?', NYAN, 5 August 1978, p. A4.

128 'A Date With Destiny', $A D W, 4$ November 1980, p. 6.

129 'A Needed Tribute', LAS, 15 January 1981, p. A6.
} 
accommodation with racists and white supremacists." ${ }^{130}$ Claiming that the United States had moved on from its racist past, Reagan's attitude to race was one of naivety, rather than disdain or hostility. ${ }^{131}$ For the purposes of this thesis, what matters about his election most is that it signalled a shift in tone in the way in which race was discussed, as Reagan preferred to use the rhetoric of colourblindness. Mainstream newspapers, for their part, treated the concerns of African Americans with less urgency than during the years of protest and ghetto revolt. Black newspapers, for their part, grew increasingly frustrated with the mainstream media's lack of concern for continued racial injustice.

The black community's pessimism effected a change in the tone regarding its calls for a King holiday. As the federal government continually failed to act on making King's birthday a holiday, the black press voiced its concerns with increasing urgency. In 1980, the NYAN noted that "Black Americans will grow ever more sceptical about shedding their blood overseas while the Congress persists in insulting us by failing to honor Dr. King." 132 The $L A S$, asking why the government had not created the holiday as early as 1973, was particularly dissatisfied by the beginning of the 1980s. ${ }^{133}$ Unimpressed by the public holidays that already existed, in December 1979 the LAS branded the government's failure "insulting to every Black man and woman who live in this nation and who hold the memory of Dr. King dear [sic]."134 By King's birthday in 1980, LAS editorials betrayed a note of resignation: "Let us make Dr. King's birthday a special day in our lives, even if White America cannot see the wisdom of such a move", a January 1980 editorial stated. ${ }^{135}$

Meanwhile, black newspapers began to view King and Malcolm X converging icons. The NYAN lamented what it saw as a dearth of African-American leadership since King's death. Having exalted King once again on his 15 January birthday, the NYAN argued that individual African-Americans "must become the new Martin and the new Malcolm [X]. For so long as we await 'a leader,' for so long as we await another

\footnotetext{
130 'Does Reagan Require a New Martin?', NYAN, 16 January 1982, p. 10.

${ }^{131}$ Gil Troy, Morning in America: How Ronald Reagan Invented the 1980s (Princeton, 2005), pp. 90-98.

132 'Martin Luther King Jr.', NYAN, 12 January 1980, p. 10.

133 'King Holiday', LAS.

134 'The Shame of It', LAS, 13 December 1979, p. A6.

135 'A Day to Recall', LAS, 10 January 1980, p. A6.
} 
Martin or a new Malcolm we shall suffer the outrages and hypocrisy of Ronald Reagan." ${ }^{136}$ No longer were King and Malcolm X polar opposites, between whom a path must be found, but now they were interchangeable leaders who could provide inspiration for a new generation of black leadership. To the black press, Malcolm X had metamorphosed into a new kind of political symbol at a time when African Americans felt they needed new energy in their leadership. Both he and King could provide models that could be simultaneously emulated.

Despite the black press's protests, the federal government's lethargy in pursuing a holiday for King reflected the mainstream media's lack of interest. While the black press agitated for a holiday in King's name, the mainstream press declined even to grant the issue significance. In one of the few such cases, the $N Y T$ briefly considered - and dismissed - the idea of closing schools in King's memory in $1975 .{ }^{137}$ As the fiftieth anniversary of King's birth passed in 1979, and the black press redoubled their calls for a holiday, mainstream editorials refused to mention such a possibility. The WP heaped praise on King and fondly remembered his address to the March on Washington. While the NYAN and LAS published editorials as strident as ever in support for the change, the WP refused to mention it. The black press could - and did - declare their dissatisfaction with the lack of progress on the issue, but the federal government faced no urgency on the issue from the mainstream press.

Mainstream newspapers began to discuss the prospect of a holiday more openly in the early 1980s, indicating that the debate had found new energy. The NYT expressed reservations about the appropriateness of the holiday, arguing it was too much for one individual, claiming that a statue would somehow be more fitting, without actually explaining why. Even though the NYT opposed the holiday, the debate around the holiday had gained salience just to be discussed in the paper's editorial pages. A holiday, according to the paper, risked marginalising "other historical black figures like Sojourner Truth, Booker T. Washington, W.E.B. DuBois and Malcolm X. If there is to be a day of tribute, let it be for all such stalwarts - and the continuing struggle for racial equality." 138 By 1982, therefore, it is reasonable to conclude that NYT had

\footnotetext{
136 'Does Reagan Require a New Martin?', NYAN. Emphasis added.

137 'Dr. King's Holiday', NYT, 15 January 1975, p. 42.

138 'How to Remember Martin Luther King', NYT, 10 December 1982, p. A34.
} 
changed its mind about Malcolm X. The paper never directly acknowledged this change, but the turnaround did not escape the notice of the NYAN, which pointed out that not only had the NYT revised its initial posthumous opinions of King, but that it had changed its mind on Malcolm X as well. ${ }^{139}$ If the editorial board of the NYT read the NYAN's criticism, it paid no heed. A year later, the paper endorsed a King holiday, again insisting that it include Malcolm X in its commemorations without any trace of irony. ${ }^{140}$

The NYT's opinion shift regarding Malcolm X, like that of most newspapers, came at the end of a protracted period free from any open deliberation on the meaning of Malcolm X's life. In the seventeen-year period between its obituary for Malcolm X and its 1982 assertion that he had been involved in a struggle for equality, only one editorial even implied any value judgement about Malcolm X. It came when a program commemorating Malcolm $\mathrm{X}$ in a public school attracted the NYT's attention. ${ }^{141}$ The WP declined to print any editorial on Malcolm X, in contrast to the occasional reference to King.

The debate over King Day revealed that newspapers did not doubt the value of King's cause. Reagan's ill-judged remark in October 1983 about whether King was a communist - "we'll know in about 35 years, won't we?", referring to sealed FBI files relating to King - gave them an opportunity to demonstrate their basic assumptions about King's worthiness. The WP, for instance, emphasised Reagan's critics, giving little space to those who agreed with him. ${ }^{142}$ Revelations about the FBI's campaign about King emerged during the 1970s, including a report that the FBI secretly encouraged King to commit suicide. The criticisms of the FBI's harassment of King provided another example of the esteem in which he was held by the mainstream and black press, as both institutions tended to use it as an example of the excesses of the bureau. The NYT and the WP both expressed serious concerns about the extent to

\footnotetext{
${ }^{139}$ William Seraile, 'Hypocrisy of New York Times', NYAN, 25 December 1982, p. 13.

140 'A Day for Martin Luther King', NYT, 11 October 1983, p. A30.

141 'Racism in the Schools', NYT, 23 February 1968, p. 32.

${ }^{142}$ Juan Williams \& Margaret Shapiro, 'President Criticized for King Statement', WP, 21 October 1983, p. A3. For more opposition to Reagan's remarks from mainstream newspapers, see 'Not a 35-Year Question', NYT, 21 October 1983, p. A34. On the date Reagan spoke, the files were in fact 44 years from being opened.
} 
which Hoover exercised a free hand to conduct the FBI's activities. ${ }^{143}$ For the black press, particularly the NYAN, the concerns ran deeper, as they associated the FBI's activities with the establishment's unspoken antipathy towards the concerns of African Americans. ${ }^{144}$ Neither the black nor the mainstream press used the FBI surveillance as evidence against King's standing, instead reporting it in the postWatergate and post-Church committee critique of the FBI.

By the early 1980s, continued pressure from the African-American community ensured that a holiday for King would eventuate. Mainstream papers found that they now had to consider the value of a holiday in King's honour. While newspapers opposed to the holiday had previously regarded the proposal with silence, they now had either to justify or reconsider their opposition. The WP, on King's birthday in 1981, came out in favour of the holiday by publishing an opinion piece by King's former associate Andrew Young, also a former Ambassador to the United Nations, supporting the holiday, while the newspaper's main editorial, on the opposite page, backed the holiday as well. ${ }^{145}$ In 1983 the NYT finally supported the King holiday, but the Atlanta Daily World ( $A D W$ ) remained unenthusiastic, arguing such a move was too expensive, despite its earlier sympathy for the holiday. ${ }^{146}$ The legislation for the holiday passed both houses of Congress with large majorities in 1983, and a reluctant President Reagan signed the legislation on 2 November 1983.

\section{Conclusion}

Prior to King and Malcolm X's assassinations, black newspapers were in a better position to appreciate convergence between the two leaders. After his death, mainstream newspapers did not grant Malcolm X anything like the same publicity that they granted King. Generally newspapers regretted his death because they opposed political violence and not because they missed his leadership. Since AfricanAmerican newspapers already paid more attention to King's concerns with urban

\footnotetext{
143 'Inciting Suicide', NYT, 21 November 1975, p. 42; 'The FBI and Martin Luther King', WP, 4 May 1976, p. 18.

144 'Discrediting Dr. King', NYAN, 3 June 1978, p. A4.

145 'Remembering Martin Luther King Jr.', WP, 15 January 1981, p. A18.

${ }^{146}$ See 'A King Holiday?', $A D W, 29$ September 1983, p. 4; 'Birthday Issue Brings Debate', $A D W, 9$ October 1983, p. 4; 'A Timely Honor for Dr. King', $A D W, 15$ January 1971, p. 4.
} 
poverty, their image of King was already closer to the image of Malcolm X conveyed in his autobiography. When King died, the black press emphasised King's connections with his black followers while mainstream newspapers described King as a figure for all Americans. The mainstream press's attitude to King meant that although they could revise their opinions of Malcolm X, they would be unable to describe him as convergent with King without significantly modifying their evaluation of King as well. The black press, viewing King as a figure for African Americans, had merely to decide that Malcolm X made a positive contribution to the black protest movement in order to do so. While such a change was not inevitable, it meant that a positive re-evaluation of Malcolm X's life would lead the black press to a greater sense of convergence than its mainstream counterparts. Once opinions on Malcolm X began to change, they had less ground to cover in order to overlap with those regarding King, since the black press already emphasised King's contributions for African Americans. 


\section{Chapter Three: Converging Politics; Contrasting Personalities}

From the mid-1980s until the early 1990s, the public images of King and particularly Malcolm X evolved. The King holiday solidified its subject's position as the principal figurehead of black political leadership but also made him less potent as a political symbol, associating him with the putatively successful civil rights movement that, to mainstream newspapers, indicated the American system had worked. The failure of the black protest movement to achieve all its goals coupled with the official sanctification of King left a space for Malcolm X as a more popular icon, and interest in him surged around the mid-1980s. By the late 1980s and early 1990s mainstream newspapers joined African-American newspapers in assuming that their readers saw King and Malcolm X as ideologically compatible, although mainstream and African-American newspapers portrayed the character of this compatibility differently. Ideological overlap did not necessitate identical public images, however, and mainstream newspapers in particular portrayed King and Malcolm X as distinct personalities who served different roles in African-American history.

This chapter will examine newspaper portrayals of King and Malcolm X from 1983, when King was established as a national hero, until the release of Malcolm X in 1992, which capped a growing resurgence in interest in Malcolm X. This chapter will first discuss the rhetorical use of King as a saint-like prophet without any direct relevance to the present day, before highlighting the role of theatre, cinema and education in providing an alternative space to contemporary political rhetoric about King as well as Malcolm X. Next, this chapter will discuss the end of the 1980s, as Malcolm X regained popularity. Mainstream newspapers, although they still preferred King as a model of African-American leadership, gave greater examination and support to Malcolm X's worldview. By the end of the period examined, both sets of newspapers were more willing than before to acknowledge convergence in King and Malcolm X's ideologies, although for mainstream newspapers this did not extend to their personalities. 


\section{Dreams unfulfilled, dreams recurring}

The confinement of King to the image of a triumphant civil rights activist, which the establishment of a federal holiday in his memory entrenched, reflected the political rhetoric of the 1970s and 1980s. Many congressional speeches commemorated King in a manner that implied the principal work of the black protest movement was complete, or at least that the progress attained outweighed the obstacles remaining. ${ }^{147}$ Awarding King the Presidential Medal of Freedom in 1977, Ronald Reagan's predecessor as president, Jimmy Carter, defined King's significance exclusively in terms of his work against segregation. ${ }^{148}$ Reagan argued that special programs to alleviate inequality violated King's plea in the "I have a dream" speech for people to be judged "not by the color of their skin, but by the content of their character."149 At the same time that Reagan rhetorically exploited King's legacy, he also prevaricated on renewing the Voting Rights Act of 1965, and moved to fill the Civil Rights Commission with people who shared his ideas that nothing more needed to be done. Reagan's speeches often paid lip service to the "traces of bigotry" that remained from the period, but minimised its significance and intimated that those "traces" would be eliminated without action from the federal government. ${ }^{150}$

The economic policies of the Reagan administration and its predecessors were more significant than their rhetorical strategies. By the 1980s, the prevailing attitude among white Americans was that a decline in overt prejudice had meant an end to racial inequality. Unfortunately this was not the case as African Americans continued to struggle relative to whites. Faced with the decline of American economic power globally, a succession of presidents from Richard Nixon to Reagan pursued businessfocused policies that increased unemployment and decreased government spending on

${ }^{147}$ Francesca Polletta, 'Legacies and Liabilities of an Insurgent past: Remembering Martin Luther King, Jr., on the House and Senate Floor', Social Science History, 22:4 (Winter 1998), pp. 489-490.

${ }_{148}$ Jimmy Carter, 'Presidential Medal of Freedom Remarks on Presenting the Medal to Dr. Jonas E. Salk and to Martin Luther King, Jr.', 11 July 1977, The American Presidency Project, http://www.presidency.ucsb.edu/ws/index.php?pid=7784, accessed 27/6/13.

${ }^{149}$ Denise Bostdorff, \& Goldzwig, Steven, 'History, Collective Memory, and the Appropriation of Martin Luther King, Jr.: Reagan's Rhetorical Legacy', Presidential Studies Quarterly, 35:4 (December 2005), pp. 661-690, esp. p. 676.

${ }^{150}$ Ronald Reagan, 'Radio Address to the Nation on the Anniversary of the Birth of Martin Luther King, Jr.', 15 January 1983, The American Presidency Project, http://www.presidency.ucsb.edu/ws/index.php?pid=41387\#ixzz1sWqiebL9, accessed 3/6/13. 
welfare programs. Both these effects disproportionately impacted African Americans. ${ }^{151}$ Residential segregation actually increased, as the incomes of black families stagnated and wealthier white families moved to the suburbs. ${ }^{152}$ While Reagan's claims of equality of opportunity were somewhat exaggerated, the number of African Americans in middle-class professions had increased, and there was a sharp increase in the number of black elected officials. ${ }^{153}$ Images of black people became more common on television, and African-American artists had more space to produce their own interpretations of, amongst other things, King and Malcolm X.

Newspapers regarded King as a great man, but usually failed to give serious consideration to his worldview. They often downplayed King's radical positions on economic redistribution or his criticisms of American foreign policy. Some simply described events in his honour that took place, without discussing what it was exactly that made King so worthy of praise, beyond some sort of vague patriotic statement. The Atlanta Daily World (ADW) anticipated the first-ever federal King holiday in 1986 with a significant front-page story that revelled in the upcoming holiday and underscored the unprecedented nature of an African American's veneration, but ultimately gave little clue as to why King would be so honoured. King was described merely as a "late civil rights leader", and the paper made no assertion regarding what King did for civil rights, leaving the reader to form their own opinion on what made King so venerable. Moreover, the paper quoted Reagan's assertion that King improved the nation by fighting racism, and the hardly controversial admonition of William Bennett, the Secretary of Education, to a group of schoolchildren that studying was important to King, and was therefore something that should be important to them. ${ }^{154} \mathrm{~A}$ Los Angeles Times (LAT) article on the King holiday described the Martin Luther King Jr. National Historic Site in Atlanta as a sacred place for many people without

\footnotetext{
${ }^{151}$ Jane Berger, "There is tragedy on both sides of the layoffs:" Privatization and the Urban Crisis in Baltimore', International Labor and Working-Class History, 71 (Spring 2007), pp. 29-49.

${ }^{152}$ Benjamin Bowser, 'Race Relations in the 1980s: The Case of the United States', Journal of Black Studies, 15:3 (March 1985), p. 313.

${ }^{153}$ Polletta, p. 492.

${ }^{154}$ Portia Scott, 'King Historic Holiday Jan. 20', $A D W$, 19 January 1986, p. 1. See also, 'In Music, Readings and Film, Salutes to Dr. King', NYT, 17 January 1986, p. C28; 'Selma Council Votes Holiday to Honor King', WP, 16 January 1986, p. A10; Zamgba Browne, 'New York ready for King's Day', NYAN, 17 January 1987, p. 25; Sadie Feddoes, 'City ready for Martin Luther King Day gala', NYAN, 19 January 1991, p. 18; 'L.A. Celebrates Life of Dr. King', LAS, 23 January 1992, p. A1.
} 
explaining anything about King, although it quoted some visitors referring to race or segregation. Another focused on the recent naming of a street to Martin Luther King Way. ${ }^{155}$ Newspapers expected their readers to know of King, but the lack of their discussion meant the newspaper did not challenge or change the readers' existing opinions.

The repeated references to King's "I have a dream" speech, which were often made to suggest racial equality had been attained, became so ubiquitous that many in the black community made an explicit attempt to go beyond it, fearing it distracted from addressing the contemporary plight of African Americans. Writing in the Los Angeles Sentinel (LAS), Ron Daniels complained the speech "reverberates monotonously throughout the nation as if to consciously mask the nightmare that exists for millions of African Americans and poor people in this country." 156 Even when newspapers wanted to argue that King was a more radical, more relevant figure than often thought, they still used the "dream" to frame this radicalism. The LAS argued that King's "life, ministry and dream", exemplified anti-racism and social progressivism. ${ }^{157}$ A New York Times (NYT) headline warned its readers that “A Day Off Is Not the Dream”, drawing on a speech from King's former colleague Wyatt Tee Walker. ${ }^{158}$ In response to an overwhelming use of the "I have a dream" speech to downplay King's radical ideas, some newspapers used the same speech to emphasise them. It is not hard to see why authors like Daniels were concerned, as King's speech to the March on Washington received so many patriotic references in the mainstream media.

All newspapers, at times, reduced King's worldview to the image of a simple dreamer. On some of the first King holiday celebrations, for instance, newspapers often referred to King only in terms of the "I have a dream" speech. ${ }^{159}$ Even when newspapers wrote

\footnotetext{
${ }^{155}$ Janny Scott, 'King Parade Puts Best Foot Forward Downtown', LAT, 18 January 1987, p. SDA1; Charles Hillinger, 'King Site Honors His Memory', LAT, 15 January 1989, p. 116. ${ }^{156}$ Ron Daniels, 'Protecting The Legacy Of Martin Luther King', LAS, 11 January 1990, p. A6.

157 'The Prophetic Vision of Martin Luther King, Jr.', LAS, 16 January 1992, p. A7. Emphasis added.

${ }^{158}$ Ari Goldman, 'A Day Off Is Not the Dream, Disciple of King Says’, NYT, 16 January 1989, p. A1.

${ }^{159}$ See, for instance, 'U.S. Reflects on Dream of a Battler for Rights', NYT, 16 January 1985, p. B3; 'Co-Hosts Of "Living The Dream”: A Tribute to Dr. M.L. King, Jr.', ADW, 17 January, 1989, p. 1; Scott \& Della Pulliam, 'Celebration Of King’s Birth Grows In Numbers, Tributes',
} 
that there was more than the "dream" to King, the newspapers only specified things they expected their readers to endorse. The black newspapers that opposed the Gulf War used his anti-Vietnam War stand - which, as mentioned, they had once strongly opposed - to justify their new opposition to a war. The New York Amsterdam News (NYAN) even printed excerpts of King's 'Beyond Vietnam' speech for his birthday in 1991 to oppose the war. ${ }^{160}$ The LAT declared on the first King holiday that there was "More Than a Dream" to King's significance, but did not associate him with anything beyond nonviolent opposition to racism, an opposition the $L A T$ implied was successful and no longer necessary. ${ }^{161}$ By this time period, if not before, the "I have a dream" speech was the main association with King.

The media, like Reagan, sometimes used King to suggest racial progress had occurred, and that Americans were no longer judged by the colour of their skin. When King's father, a well-known activist in his own right, died in 1984, the Washington Post (WP) implied that the main aims of the black protest movement had been achieved. To do so, the newspaper emphasised the elder King's origins as the son of poor, illiterate, black southerners; the successes of his son in leading the civil rights movement; and his role as a black southerner in securing Carter, a white southern governor, the Democratic Party's nomination for president, an act which the newspaper interpreted as a great historical symbol of racial reconciliation, and which happened to leave a white American in a position of power. ${ }^{162}$ The newspaper celebrated the first Martin Luther King Day by looking back on its edition from exactly thirty years earlier, highlighting the stories relating to continued racial segregation in Virginia. The editorial emphasised the "revolution" in the South for which King fought, although it made a vague acknowledgement of "the next steps" in the black protest movement. ${ }^{163}$ By looking back rather than forward, the newspaper associated King at first with the

\footnotetext{
$A D W, 14$ January 1990, p. 1; Susan Schmidt, 'Martin Luther King III: Keeping Father's Dream', WP, 13 January 1986', p. B4; Debra Behr, 'A Dream to Remember', LAT, 13 January 1989 , p. B1.

160 'Happy Birthday Martin!!: A time to break silence', NYAN, 19 January 1991, p. 27.

161 'More Than a Dream', LAT, 20 January 1986, p. 4.

${ }^{162}$ Martin Weil, 'Martin Luther King Sr., 84, Dies', WP, 12 November 1984, p. B6; 'Martin

Luther King Sr.', WP, 13 November 1984, p. 14.

163 'The King Holiday', WP, 20 January 1986, p. A18; 'Dr. King’s Day', WP, 19 January

1987, p. A17.
} 
South, and with the completed battle to end segregation in that region. It said nothing about King's relevance to the present day or the incomplete battles King fought.

While other black newspapers remained sympathetic to black protest, the $A D W$ continued to express a generally conservative voice in the African-American public sphere. Grateful for the King holiday, despite its earlier ambivalence, the $A D W$ welcomed the move as a triumph for African Americans and a vindication of its endorsement of Reagan in 1980. The newspaper had glossed over Reagan's prior opposition to the Bill, and repeated its endorsement in 1984. The $A D W$ even drew on King's legacy to justify its support of Reagan's support for the anti-Sandinista Contras in Nicaragua, seldom a major concern of black newspapers.

On King Day 1989, as Reagan prepared to leave office, the $A D W$ saluted both King and Reagan. Praising King's nonviolence, it argued that the "cornerstone of Reagan's eight-year administration was peace with justice by strength", and that King also held "peace with justice" to be crucial. Having lauded King's commitment to nonviolence, the paper then strangely channelled King's legacy to endorse Reagan's foreign policy, choosing remarkably Reaganesque language to chide other King supporters for their opposition to "checking the threat at our back door." 164 The newspaper, on one hand, enthused about King's nonviolence, and, on the other, argued for military force as an appropriate response to a perceived threat. Having reinforced the importance of nonviolence in King's worldview, the $A D W$ cast aside King's opposition to the Vietnam War, his scepticism of military intervention, and his public opposition to Reagan's presidential candidacy in 1968, to argue that military force was appropriate in response to the situation in Central America. The $A D W$ 's doublethink on nonviolence and Reagan's foreign policy was a particularly clear example of a contradictory tendency in the media portrayal of King. Sometimes, as in the $A D W^{\prime} \mathrm{s}$ case, this meant an interpretation that King himself likely would have opposed.

\section{$\underline{\text { Stages, screens, and classrooms }}$}

164 'Peace With Freedom Remains The Top Goal', $A D W, 15$ January, 1989, p. 4. For earlier $A D W$ support of nonviolence, see 'Nonviolence Remains the Main Challenge!', $A D W, 18$ January 1987, p. 4. 
During the mid to late 1980s, educational and cultural spheres provided alternative interpretations of King and Malcolm X. Black playwrights and authors published in detail their own interpretations of the black protest movement, providing a forum for representing Malcolm X in particular in a manner different to the dominant image of him. The critically acclaimed documentary series Eyes on the Prize provided a reexamination of King and Malcolm X, that sought to extend King's legacy beyond civil rights and into anti-poverty and anti-war activism, while also emphasising Malcolm X's importance to the movement. At about the same time Malcolm X and particularly King became more common as subjects of discussion in classrooms from elementary schools through to universities. Spike Lee's well-received film Do the Right Thing, featuring King and Malcolm $X$ as alternative symbols for nonviolence and violence, encouraged a rethinking of King and Malcolm X.

Cultural productions offered another sphere for the interpretation of King and Malcolm X. Malcolm X's life inspired numerous plays, films and even operas, some of which were well received and favourably reviewed. The mainstream and black press covered these productions, although the black press generally expressed more interest. Regardless of the reception of the productions themselves, both black and mainstream critics agreed that Malcolm X's life was worth exploring. The WP, in reference to $X$, an opera on Malcolm X, described him as one of the greatest "tragic heroes" of recent years. ${ }^{165}$ The NYT hailed him as "legendary". ${ }^{166}$

An actor depicted King in a stage production entitled I Have a Dream in New York City, in 1985 and 1986, reviewed by both the NYT and the NYAN. The musical production chronicled King's life, from the Montgomery Boycott to his assassination, drawing heavily on King's own work. The NYAN's Abiola Sinclair wrote eleven paragraphs on the play, the first four of which made no reference to the show, lamenting instead the failure of many Americans, especially the young, to remember King's life. Sinclair only briefly described the show, praising it strongly, but doing so more in terms of its educational value, rather than its merits as a dramatic production. The NYT's Stephen Holden was less interested in the show's potential to influence popular memory. Describing, in typical NYT language, King's position as a great

\footnotetext{
165 Joseph McLellan, ' $\mathrm{X}$ ': Opera as History', WP, 13 October 1985, p. D1.

${ }^{166}$ Gerald Fraser, 'Stage: Duane Shepard As 'Brother Malcolm X', NYT, 8 June 1986, p. 74.
} 
American prophet and martyr, Holden described the play in terms of its theatrical qualities, contradicting Sinclair's praise. Holden found the actor who played King unconvincing, and ended by reasserting his admiration for King, but not the play which had failed to do justice to his charisma. Reviewing the production, both papers illustrated some of their differing emphases in remembering King. The main priority for the NYAN was the play's educational benefits, while the NYT was more interested in the drama, and the theatrical qualities of the representation of King's life.

The most direct attempt to reconcile King and Malcolm X on stage or screen was Jeff Stetson's The Meeting. First performed in 1987, the play imagined a discussion between the two a week before Malcolm X's murder. The reviews illustrated changes in their public images. Almost no reviewers found the play's major premise, that King and Malcolm X could find common ground, incredible. ${ }^{167}$ Still, mainstream newspapers in particular wanted the production to flesh out the nuances of their ideologies. The NYT's reviewer complained they resembled "competing brands of soft drinks". ${ }^{168}$ Agreeing, the WP's Pamela Sommers felt that they were not really having "a conversation." 169 Sinclair, writing in the NYAN, noted that King was often too placid, and difficult to dramatise for fear of detracting from the mythology that had made him into a secular saint. The end result, to Sinclair, was that plays featuring King were "boring, redundant and often interchangeable." 170 Some black critics found the production necessary to remind people of their legacies. The differences between them, the southern preacher versus the streetwise northerner, seemed clear, but also seemed too superficial. The mainstream newspapers, in particular, noticed this apparent deficiency, but the black newspapers overlooked it, due to their pleasure at the presence of two black icons on the stage acting what the black newspapers had already conceived of as their actual relationship. Reviews of The Meeting showed mainstream media had to deal with a new way of comparing King and Malcolm X but had not yet come to share the view of the black press about their fundamental similarity.

\footnotetext{
${ }^{167}$ Mark Smith, 'King and Malcolm X Take a 'Meeting', LAT, 23 February 1989, p. D10.

${ }^{168}$ Walter Goodman, 'An Imaginary Meeting of Dr. King and Malcolm X', NYT, 3 May 1989, p. C26.

${ }^{169}$ Pamela Sommers, “Meeting': Malcolm \& King Collide', WP, 14 September 1990, p. C4. Emphasis in original.

${ }^{170}$ Abiola Sinclair, 'Malcolm X and King duel', NYAN, 18 April 1987, p. 23.
} 
That same year the initial series of Eyes on the Prize was broadcast on Public Broadcasting Service (PBS), covering the 'classical' phase of the movement, from 1954 to 1965 . The largely uncontroversial nature of the topic had helped it receive funding. Educating his audience about the movement had motivated series creator Henry Hampton. Children needed to be taught about the movement, while Hampton also believed that adults also needed a "historical vocabulary" about the movement. Hampton lamented to the WP that the 1980s had featured a "retreat" from the government's efforts racism, and accused Reagan's successor, George H. W. Bush, of neglecting racial injustice. A major goal, therefore, was to produce another narrative of the movement, to rival the dominant New Right narrative that Reagan had been expressing. The first series, featuring King as its central character, focused on the struggle against segregation in the South. Hampton told the WP that making the first series of Eyes on the Prize necessitated the second. ${ }^{171}$

The second series, airing in 1990, examined the move northward and the splintering of the movement from 1965 as Black Power emerged to challenge notions of integration. It used Malcolm $\mathrm{X}$ as its starting point in an episode which also included King, emphasising the unsettling effect Malcolm X had on many of the Northern white liberals who had hitherto been enthusiastic supporters of the black protest movement. A later episode examined King's northern campaign and the Poor People's Movement together with his opposition to the Vietnam War, stressing his radical phase and willingness to risk a break with the Johnson administration. Putting them both into the second series transmitted the historians' interpretations of their similarities and King's radicalism to a wider audience of teachers, students, and the PBS-watching public who came from the more educated and prosperous segments of the American public.

Eyes on the Prize helped reshape newspapers' perceptions of King and Malcolm X. Charles Griffin has examined the role of Eyes on the Prize on public memory. He argued the documentary series reinforced perceptions of a civil rights "movement" that

${ }^{171}$ Patricia Brennan, 'Henry Hampton, Still Telling America's Story of Civil Rights', WP, 14 January 1990, p. 9. 
was a coherent social force that could not be resisted. ${ }^{172}$ In shaping public memory of the civil rights movement, Eyes on the Prize, and the resultant press coverage, provided a voice that legitimised Malcolm $\mathrm{X}$ as a leader, and that placed civil rights as part of a broader, unresolved movement. Press coverage of Eyes indicates that the series was certainly well received. The $N Y T$ listed the second series as a highlight of the television year. The first series reinforced the idea that King was mainly a Southern figure, while the second series focused on the black protest movement and King's involvement with Northern activists. As some newspapers followed suit, its effect in many ways was to weaken the division between the two, as Malcolm X and King were associated with the North, and by extension unresolved issues.

Continuing Hampton's theme of education, educators and community leaders used King as a teaching tool. Newspaper articles often described these lessons, especially around the King holiday. Papers detailed Reagan's visits to schools to praise King. Black newspapers like the NYAN discussed students learning about King. ${ }^{173}$ The WP discussed multiracial classrooms learning about him. ${ }^{174}$ Malcolm $\mathrm{X}$ also provided a teaching tool, but newspapers reported the students learning about him were invariably black. ${ }^{175}$ King was in the curriculum, teaching students of all races about the movement's successes in the 1950s and 1960s. As the academic field of Black Studies proliferated, more university students studied The Autobiography of Malcolm $X$ and works of King's such as 'Letter from a Birmingham Jail' as the civil rights movement also became inserted into the American history curriculum.

Although theatres, classrooms, and PBS documentaries helped reinterpret King and Malcolm X, cinema was arguably the most effective medium for transmitting a new interpretation of the two. In 1989 Lee's Do the Right Thing examined the relationship between King and Malcolm X, and their continuing relevance for African Americans. The film depicted a character peddling copies of a photo of the one meeting between King and Malcolm. Narrating the racial tension in an inner city neighbourhood from

\footnotetext{
${ }^{172}$ Charles Griffin, 'Movement as Memory Significant Form in Eyes on the Prize', Communication Studies, 54:2 (Summer 2003), pp. 196-210.

${ }^{173}$ Harold L. Jamison, 'King remembered in Harlem program', NYAN, 23 January 1988, p. 10.

${ }^{174}$ Patrice Gaines-Carter, 'Va. Students Learn King's Lesson', WP, 16 January 1989, p. A6.

175 'Hostility Greets Students at Black School in White Area of Detroit', NYT, 2 December 1992, p. B12.
} 
the perspective of an African-American pizza delivery worker, the film questioned whether the right method of channelling black anger was violence or nonviolence, and used King and Malcolm X to symbolise the two. The film ended with a race riot, and its final scene presented competing quotes on violence, one from King opposing violence, and one from Malcolm X justifying it, signalling an unresolved choice facing the African-American community. When asked about the choice between the two, Lee answered that he was increasingly drawn towards Malcolm X's philosophy of selfdefence, saying, "Nonviolence had its time." ${ }^{176}$ Newspapers, film critics, and viewers, however, did not necessarily see the choice the same way.

While both the black and the mainstream press appreciated the film, the mainstream press paid greater attention to the representation of race relations within the film and to the depiction of King and Malcolm X providing an unresolved dilemma for African Americans regarding the use of violence. The NYT, appreciating the film, invited a panel of experts, including Malcolm X's widow, to discuss it. The panel members, who were generally impressed by the film, discussed the symbolism of King and Malcolm X, as shorthand for the choice between nonviolent resistance and violence, and did not easily reach a conclusion as to what the better alternative was. ${ }^{177}$ The black press did not find the King-Malcolm X dichotomy to be a particularly noteworthy part of the film. Do the Right Thing received considerable praise from the black press, but they did not single out the kinship between King and Malcolm X since they did not consider it a novel idea, in contrast to the mainstream press, which still stressed the choice described in the NYT panel. ${ }^{178}$ If anything, the black press viewed the Lee's treatment of the two to be shallow, as the $A D W$ of all papers complained that Lee was ignoring Malcolm X's ideology to liken him to King. ${ }^{179}$ The binary proposition was not that new to the mainstream press, as the first chapter has shown, but Do the Right

\footnotetext{
176 Jack Mathews, 'Controversial Film for a Long Hot Summer', LAT, 22 May 1989, p. E1.

177 ' 'Do the Right Thing': Issues and Images', NYT, 9 July 1989, p. H1.

${ }^{178}$ Sinclair, "Do the Right Thing' - summer's best', NYAN, 1 July 1989, p. 30; Elizabeth Green, 'Spike Lee 'Does Bed-Stuy Right', NYAN, 8 July 1989, p. 19. For one of the few articles in the black press that attached any significance to the film's King-Malcolm X depiction, see Alan Bell, 'Spike Lee Does The 'Rite' Thing', LAS, 29 June 1989, p. B8, the only $L A S$ article from 1989 to refer to the film and either King or Malcolm X. Jack Mathews, 'Controversial Film for a Long Hot Summer', LAT, 22 May 1989, p. E1; 'Spike Lee's Cannes Shake-Up', SP, 22 May 1989, p. B1; Sheila Benson, 'Spike Lee Comes of Age', LAT, 30 June 1989, p. J1D, Amy Schwartz, 'Spike Lee Sees a Terrible Thing', WP, 8 August 1989.

${ }^{179}$ Angela Chamblee, 'The Image Of Malcolm X In Popular Culture Today', $A D W, 12$ November 1992, p. 13.
} 
Thing encouraged the mainstream press to look at the choice in a new way, that did not unthinkingly endorse one while rejecting the other.

\section{$\underline{\text { King as persistent icon; Malcolm } X \text { as resurgent icon }}$}

In 1989 and 1990, King's position as a saintly hero faced an apparent threat from two allegations about his moral conduct. In 1989, King's former colleague Ralph Abernathy released his memoirs, which included the claim that King engaged in multiple extramarital affairs, and spent the night prior to his assassination with two women, neither of whom was his wife. The allegation that King had been an unfaithful husband was not new. FBI surveillance recorded King's indiscretions in detail; historians David Garrow and Taylor Branch had discussed them in earlier books published earlier in the $1980 \mathrm{~s}$, Garrow arguing that the affairs were critical to the FBI's hounding of King. ${ }^{180}$ The mainstream media had paid only a little attention to both authors, making little more than passing reference to his sex life. ${ }^{181}$ Black leaders, also largely unperturbed by Garrow and Branch's publications, considered Abernathy's actions a serious breach of trust against King.

To much greater surprise, in 1990 researchers at the King Papers Project at Stanford University revealed that King's doctoral dissertation included extensive passages copied, almost verbatim and without proper attribution, from a previous doctoral dissertation at the same university. The researchers, led by Clayborne Carson, could not discern whether King deliberately plagiarised these segments, but still expressed shock at the scale of the offence. The black press ignored the news almost completely, and excused King's actions when they did consider them. ${ }^{182}$ For them, the plagiarism charges did not carry the same weight of betrayal as Abernathy's book did. The mainstream press took some interest in the plagiarism revelations, more so than they

\footnotetext{
${ }^{180}$ David Garrow, Bearing the Cross: Martin Luther King, Jr., and the Southern Christian Leadership Conference, New York, 1986; Taylor Branch, Parting the Waters: America in the King Years, 1954-1963, New York, 1988.

${ }^{181}$ Howell Raines, 'Driven to Martyrdom', NYT, 30 November 1986, p. 360; Dorothy Gilliam, 'Different Era, Same Arrogance', WP, 4 December 1986, p. B3, are two of the few mainstream articles from the time referencing King's personal affairs.

${ }^{182}$ Sinclair, 'Martin Luther King Jr. and the plagiarism charges', NYAN, 1 December 1990, p. 24.
} 
had done with the Abernathy memoirs. Upon the public announcement of the discovery in November 1990, the NYT and WP reported the story on their front pages, and detailed the shock that King researchers had felt upon uncovering the plagiarism. ${ }^{183}$ The story quickly lost its attraction for the mainstream press as well, however.

Although neither the black nor the mainstream press let the scandals change their view of King, the black press demonstrated greater insecurity about the matter, fearing that the mainstream media aimed to denigrate King. Black newspapers mirrored the African-American leaders' disapproval of Abernathy's book. Despite their clear distaste, though, the newspapers allowed a measure of debate. Some of their stories quoted Abernathy extensively. ${ }^{184}$ The NYAN also published a review that argued the controversy had overshadowed the fact that Abernathy's book was actually a revealing, well-written look into King's life and the black protest movement. ${ }^{185}$ Unlike the black press, the mainstream press did not regard King's fall from grace as likely. Neither promiscuity nor theft of ideas in a doctoral dissertation detracted from King's actions as a leader of the black protest movement. The NYT spoke for the mainstream press in arguing in its editorial pages that King's plagiarism did not impinge on his qualities as a leader. ${ }^{186}$ King's infidelity, after all, placed him in the company of leaders like John F. Kennedy, who remained popular despite posthumous revelations regarding their personal lives. King had secured such a strong place in sectors of public memory, such as educational curricula and national holidays, that it was impolitic to dislodge him. Since the two scandals about King disappeared so quickly, they illustrated mainly how much he had become venerated. The black and mainstream press alike almost completely ignored the revelations the year after they surfaced. ${ }^{187}$

\footnotetext{
${ }^{183}$ Dan Balz, 'Scholars Question Portions Of King’s Academic Papers', WP, 10 November 1990, p. A1; Anthony De Palma, 'Plagiarism Seen by Scholars In King's Ph.D. Dissertation', NYT, 10 November 1990, p. 1; Garrow, 'How King Borrowed', WP 18 November 1990, p. C1. ${ }^{184}$ Ron Dungee, 'M.L.K. 'Assassinated' By Closest Friend', LAS, 19 October 1989, p. A1.

${ }^{185}$ Greg Harris, 'Abernathy's memoirs', NYAN, 21 October 1989, p. 40.

${ }^{186}$ Browne, 'Activists lash out at Rev. Abernathy's memoirs', NYAN, 21 October 1989, p. 38; 'What Dr. King Wrote, and What He Did', NYT, 13 November 1990, p. A30.

${ }^{187}$ See, for instance, 'Hail to the King', LAS, 17 January 1991; 'How Long, America?', LAT, 21 January 1991; 'Dr. King's Enduring Message', 21 January 1991, p. A20; 'Martin Luther King's Moral Authority', NYT, 12 January 1991, p. A16, which briefly mentions, and marginalises, the accusations of plagiarism.
} 
Despite the revelations, newspapers increasingly used King as a moral paragon who could offer wisdom on contemporary race relations. The mainstream press would sometimes use King on racial matters, or to make a figure of whom they approved look better - a technique they would eventually escalate in the twenty-first century. ${ }^{188}$ Other editorials, in both kinds of newspapers, used the King holiday by rhetorically asking what King, a higher moral authority, would make of contemporary American race relations. ${ }^{189}$ The NYAN used King's rhetoric in appeal for greater unity among New York's racial minorities. ${ }^{190}$ The newspapers also used him in this context to buttress their support for greater anti-poverty and anti-discrimination policies, in opposition to the Reagan administration. As ever, black newspapers were more likely than mainstream newspapers to do this, and to express this support in a racialised context.

While King continued to be an iconic figure for all Americans, Malcolm X received far more sophisticated attention from the mainstream press than he had ever received before. Responding to the new interpretations circulating in cultural and educational spheres, mainstream newspapers paid increasingly positive attention to Malcolm X's worldview. In stark contrast to their coverage during his lifetime, newspapers like the NYT or WP quoted people who admired Malcolm X. Their articles even implied that Malcolm X was a positive force during his lifetime, an unthinkable concept twentyfive years earlier. Reporting on commemorations of Malcolm X on the twenty-fifth anniversary of his assassination, the WP acknowledged the controversy surrounding Malcolm X's life, but did not quote any critical comments. Articles about subjects far removed from black liberation sometimes used him as a shorthand reference for something positive, sometimes as a "hero", comparable to King or even Superman. Association with Malcolm X counted as a point in favour of his brother Robert Little, whose appointment as head of New York's Child Welfare Administration in 1990 the NYT welcomed. ${ }^{191}$ Like the black press, mainstream newspapers now assumed readers

\footnotetext{
188 'Brooklyn's Exceptional Preacher', NYT, 30 June 1990, p. 22.

189 'How to Overcome', NYT, 19 January 1987, p. A16; 'Martin would have laughed...and cried', NYAN, 21 January 1989, p. 12.

190 'Leaders... Choose someone', NYAN, 9 February 1985, p. 14; 'A Time for Healing Wounds', LAS, 13 June 1991, p. A6; LAS, 14 May 1992, p. A19.

${ }^{191}$ Elizabeth Castor Washington, 'Whatever Happened to the Hero?', WP, 20 June 1990, p. C1; Felicia Lee, 'New Child Welfare Chief', NYT, 18 November 1990, p. 38.
} 
held favourable opinions about Malcolm $\mathrm{X}$ as well as King while they discussed his ideas in greater detail.

The change in coverage of Malcolm $X$ was qualitative and quantitative (see figure 3.1). The strength of Malcolm X's resurgence is undeniable, and noticeable in the increase in the number of articles mentioning him around the late 1980s and early 1990s. Earlier in the 1980s, the mainstream press had rarely mentioned Malcolm X. The twenty-fifth anniversary of Malcolm X's death in 1990 received much greater attention, and Malcolm X eventually overtook King in the NYAN in 1992, the year of Lee's successful Malcolm X. At this point, Malcolm X had become more present in the media, in terms of sheer quantity of coverage, than he ever had been during his lifetime. The resurgence in interest did not appear permanent, however, as mentions of Malcolm X dropped off sharply a couple of years after the film's release. In their assessment of Malcolm X's significance, mainstream newspapers had gradually reached a similar view to their black counterparts, legitimising him as an icon of black protest, and recognising the need for protest about issues like police brutality.

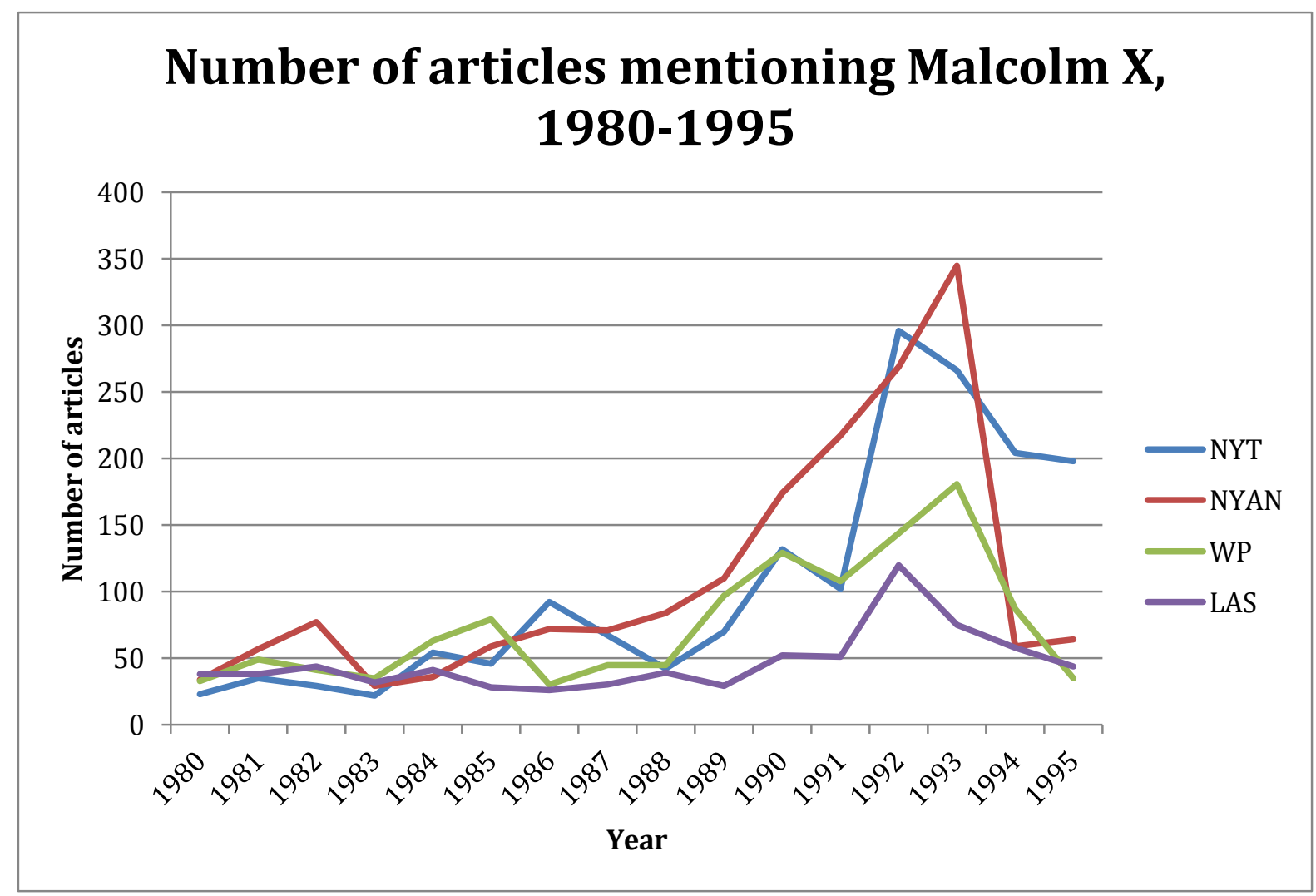

Figure 3.1 
The black press appreciated the role Hampton gave Malcolm X in Eyes on the Prize, but they wrote about this role as confirming views they already held. Benjamin Chavis, a black political leader and future executive director of the NAACP, wrote approvingly and extensively in the NYAN about the role of Malcolm $\mathrm{X}$ as a "teacher" in the documentary. ${ }^{192}$ Some, like Larry Aubry in the $L A S$, wrote about the similarity of the problems of 1960 and 1990. ${ }^{193}$ The NYT argued Malcolm X's contribution was to strengthen King's, a similar argument to the one put forward by Eyes on the Prize. Malcolm X was not the principal figure in the series, but it helped place him within the same protest movement as King. As the NYT's Walter Goodman put it, they belonged, "in their separate ways", to a line of black protest stretching back to the Underground Railroad and forward to the present. ${ }^{194}$ Such a characterisation allowed for convergence between the two, and a sense of distinctness, especially as the mainstream media treated King's anti-poverty activism with greater sympathy.

Having previously described King as figure of a bygone era, by the late 1980s the WP insisted that his work was still unfinished, although it remained vague regarding requirements to complete. Its editorials expressed concern about poverty, and consistently criticised the Reagan administration's cuts to welfare spending. The WP joined the rest of the mainstream media in demonstrating an increased awareness of King's dedication to social justice causes. In contrast to the more pessimistic black press, the NYT, WP, and LAT generally praised the progress in race relations since King's death, before pointing out that deep racial inequality and poverty remained. They argued that continued progress was imperative for the government. ${ }^{195}$ The NYT expressed particular concern with housing legislation, and often used King's memory to advocate in favour of better funding for programs that housed people living on low incomes. ${ }^{196}$ Although these concerns mirrored those of the black press, the mainstream newspapers demonstrated considerably more faith in the American system's ability to

\footnotetext{
${ }^{192}$ Benjamin Chavis, 'Eyes on the Prize: Part Two', NYAN, 6 January 1990, p. 13.

${ }^{193}$ Larry Aubry, 'Eyes On The Problem', LAS, 1 March 1990, p. A7.

${ }^{194}$ Goodman, 'Recalling the Pursuit of a Still-Elusive Prize', NYT, 15 January 1990, p. C11.

195 'Gains to Be Made...', WP, 16 January 1989, p. A20; 'Much to Cheer, Much to Do', LAT, 18 January 1988, p. C6; 'Progress \& Promise', LAT, 4 April 1988, p. C6.

196 'A Better Way to Honor MLK', NYT, 26 April 1991, p. A28; 'After 20 Years, Fair Housing Teeth', NYT, 8 August 1988, p. A16.
} 
solve the problem than the black newspapers did. ${ }^{197}$ King's birthday became an annual occasion for newspapers to discuss the extent of economic and racial equality while remaining less clear as to what it might take to transform the situation.

Although King was outspoken on poverty and the underperformance of African Americans, his veneration left a space for Malcolm $X$ to be made more popular through strong links to the causes of urban poverty. ${ }^{198}$ During his lifetime, King's value for the black press lay in his significance for African Americans. By the 1980s, he was a figure for all Americans, rather than African Americans in particular. His life was something in which African Americans could take particular pride, as they had someone who the nation acknowledged. As one NYT journalist noted, King's achievements seemed "saintly and superhuman", but more appreciated by whites than blacks. In the early 1990s, it seemed to black youth that Malcolm X more directly related to their concerns. ${ }^{199}$ Praised by figures not associated with black concerns, King's image lost some of its power to appeal to alienated young people. King's enshrinement in a national day, and the fact that he could be readily associated with outdated concerns like battling Jim Crow made it difficult for them to relate to him. Although the black press continued to underscore King's value to African Americans, the prevalent mainstream image of King as a universal figure retained a hold, making King less obviously relevant.

Malcolm X's enduring appeal, by contrast, lay in his edginess, his ability to talk directly to black people without dealing with the concerns of white people. Indicating the racial exclusivity of Malcolm X, the $L A S$ reported with a note of indignation that black companies had not profited as much from Malcolm $X$ as they expected because, according to the $L A S$, white firms took more profit than they should have. ${ }^{200}$ Commentators praising his leadership wrote almost exclusively of his value to African Americans, not the country as a whole. While King was the positive, acceptable face

\footnotetext{
${ }^{197}$ See, for instance, 'After 20 Years, Fair Housing Teeth', NYT, 8 August 1988, p. A16, which emphasises the apparent success of some legislative bodies in dealing with the issue.

${ }^{198}$ For Malcolm X being associated with black youth, see Doug Henderson, 'After 25 years

Malcolm X is back', NYAN, 9 June 1990, p. 15; Lynne Duke, 'Malcolm X as Teacher', WP, 19 November 1992, p. A1.

${ }^{199}$ Isabel Wilkerson, 'Young Believe MX is Still Speaking to Them', NYT, 18 November 1992, p. A1.

200 'White Press Gets \$ 'From 'Malcolm X’, LAS, 24 December 1992, p. A2.
} 
of the black protest movement, Malcolm X's position as the more radical alternative meant that white Americans could never embrace him as a hero as easily as African Americans could. Mainstream newspapers by the early 1990s also accepted Malcolm $\mathrm{X}$ 's value as a positive figure as they allowed greater space for black voices in their pages.

To enable a more positive reassessment of Malcolm X, black and mainstream newspapers had to overcome his previous association with violence. They did this by justifying his stance on violence, and by marginalising it. Usually, they quoted interview subjects to explain, or negotiate, his associations with violence. ${ }^{201}$ Some black newspapers commented directly, differentiating between violence and selfdefence. The $L A S$ explained the distinction thus, "Malcolm $\mathrm{X}$ did not advocate violence, but encouraged Blacks to defend themselves against the vigilante violence of racist individuals and groups." 202 The NYT used a supporter of Malcolm X in a similar manner. ${ }^{203}$ The WP, reporting a debate on Malcolm X, described him as an advocate of self-defence, in contrast to the nonviolence of most civil rights leaders. ${ }^{204}$ By qualifying Malcolm X's attitudes to violence, newspapers removed a previous obstacle to a positive portrayal and went beyond the simplistic representation of him as a radical alternative to King.

While the newspapers endeavoured to explain Malcolm X's stance on violence, they marginalised it with a new set of frames emphasising his value as a role model for African Americans, and - particularly in black newspapers - his critique of racism in American society. The new proliferation of his message was most noticeable in the NYAN, his former 'home' newspaper, but his worldview received significant coverage in mainstream newspapers and black newspapers from outside New York who found greater depth and nuance in his worldview. While the $L A S$ had regarded him with mistrust during his lifetime, the newspaper by the late 1980s had created the image of a thoroughly admirable leader for African Americans, and articles regularly described

\footnotetext{
${ }^{201}$ See, for instance, 'Widow, 2 others get Malcolm X awards', NYAN, 25 May 1985, p. 9.

202 'MX Would Be Appalled By Some Youths Today', LAS, 5 March 1992, p. A1.

${ }^{203}$ Fraser, 'The Voice of Malcolm X Has an Audience Again', NYT, 20 February 1990, p. B3.

${ }^{204}$ Lynda Richardson, 'Remembering a Man and His Enduring Legacy', WP, 22 February 1990, p. D3.
} 
events held in his memory, or discussed his relevance to contemporary times. ${ }^{205}$ Not only did newspapers justify Malcolm X's attitudes to violence, but they also marginalised their importance, compared with other aspects of Malcolm X's worldview, such as his ability to instil self-respect in black youth, particularly through his own personal example.

\section{A new choice?}

If Do the Right Thing had encouraged the mainstream press to rethink King and Malcolm X's relationship with each other, Lee's next film, Malcolm X, encouraged newspapers to examine Malcolm X increasingly on his own merits, and even white conservatives began to express admiration for him, to the uneasiness of some of Malcolm X's contemporaries. Before newspapers could reach this point, though, King and Malcolm X's attitudes to violence, and their relationship with each other, became more relevant as race relations were forced back into the forefront of the American media. Rodney King, an African-American motorist, was severely beaten by Los Angeles police in an incident secretly videotaped by a bystander on 3 March 1991. The acquittal in April the next year of four officers involved in the incident led to riots in Southwest Los Angeles. The episode reintroduced the spectre of race riots to the forefront of media discourse. All mainstream and black newspapers regarded the incident and the riots seriously, although the Los Angeles papers saw it as most important. The differences in their approach illustrated the differences in their views of American race relations. The $L A T$ presented the incident as a new event without any long-term causes, something that came unexpectedly, while the LAS regarded it simply as the next in a long line of cases of police brutality against African Americans. ${ }^{206}$ The LAT also presented the aftermath of the incident as a conflict between the police establishment and the political establishment, while the LAS portrayed the black community of Los Angeles as the main protagonists. ${ }^{207}$ The Rodney King incident had implications for the public images of Martin Luther King and Malcolm X.

\footnotetext{
${ }^{205}$ See, for instance, Sheila Rose, 'What Malcolm X Means To Me', LAS, 19 November 1992, p. B6. For commemoration, see 'Birthday of Malcolm X Observed', $L A S, 19$ May 1988, p. A11; 'Malcolm X Observed', LAS, 17 May 1990, p. C11.

${ }^{206}$ Ronald Jacobs, 'Civil Society and Crisis: Culture, Discourse, and the Rodney King Beating', American Journal of Sociology, 101:5 (March 1996), p. 1266.

${ }^{207}$ Jacobs, p. 1249.
} 
The riots convinced the LAT that Martin Luther King's legacy of nonviolence was under threat. The newspaper expressed concern at the number of African-American youths who mentioned Malcolm $\mathrm{X}$ as an icon. The $L A T$ claimed that the rioters followed Malcolm X's dictum of "freedom by any means necessary", rather than King's nonviolence. To the LAT, King's nonviolence was under threat from Malcolm X's ideological disciples, and the newspaper could not settle entirely on a response. While on the one hand, it associated Malcolm X with violence or disorder it also suggested another possibility. The LAT intimated that Malcolm X and King could go together, much like other newspapers. The LAT tried to make Malcolm X seem more like King by emphasising his belief in racial "brotherhood". ${ }^{208}$ The newspaper also quoted the black followers of King who believed in economic justice. As the spectre of racial violence was again raised, the $L A T$ concerned itself with the attack on King's legacy. The $N Y T$ and $W P$ both took more progressive stances on the riots. The NYT bemoaned the lack of King-like leadership, arguing that solving "the Problems of the Ghetto" was but an extension of King's earlier work. ${ }^{209}$

The Rodney King incident demonstrated that Martin Luther King was still the paramount icon of African-American resistance to racism. Malcolm X was less likely to be referenced in the mainstream press in articles about the incident. Rather than placing the newly-rehabilitated Malcolm $\mathrm{X}$ as the principal spokesman of deprived African Americans, newspapers instead brought out the often under acknowledged King of social justice and anti-poverty. While the Rodney King incident demonstrated that Malcolm X still had power as an icon of African-American protest, it also showed that there were limits to that power. Martin Luther King, both because of his stature in American society and because of his commitment to the poor, remained the preferred source of inspiration.

Black editors managed to use King and Malcolm X separately from each other in the aftermath of the riots. The newspapers viewed the riots as the result of a larger trend of white supremacy in America, and symptomatic of what was to come unless the

${ }^{208}$ Lucille Renwick, 'Is the Dream Still Alive?', LAT, 17 January 1993, p. 3.

${ }^{209}$ Jason Deparle, 'The Civil Rights Battle Was Easy Next to the Problems of the Ghetto', NYT, 17 May 1992, p. E1. 
authorities began to take greater care of the nation's inner cities. A number of NYAN articles used Malcolm X, separately from Martin Luther King, to justify an activist response to the Rodney King incident. Malcolm X's moral authority rested on the idea of black self-help, and the indictment of white society. ${ }^{210}$ Black newspapers considered these traits important in the situation. However, they also found Martin Luther King's advice to be helpful. Daniels in the $L A S$ raised King's increasingly public concern with "equity and parity". ${ }^{211}$ The newspaper interviewed several black Christian ministers in Los Angeles who were offering support to the black community. The first minister the LAS quoted compared Rodney King to Martin Luther King. ${ }^{212}$ Charles Baillou in the NYAN argued that Rodney King's beating served as a reminder that black lives still seemed less important than white ones, and emphasised Martin Luther King's commitment to economic justice. ${ }^{213}$ Whereas the mainstream press had preferred Martin Luther King's leadership, the black press examined the relevance of both King and Malcolm X to the incident separately, and regarded both men as valuable but not identical icons of protest.

The Rodney King incident provided the clearest illustration that police brutality was not exclusively a problem for the South in the 1960s, but for the whole country in the 1990s, leading Lee to use it during the opening of his adaptation of Malcolm X's autobiography, Malcolm X, released in 1992 and starring Denzel Washington in the title role. Many people, led by poet Amiri Baraka, believed that Lee might make Malcolm X, at times a fierce critic of the black middle class, resemble the saintly King. The fears revolved around the fact that Malcolm X had always been a figure of class significance, as well as racial. In a further reflection of just how far mainstream newspapers had progressed in acknowledging debates and difference within black communities, the $N Y T$ gave significant coverage to the debate, particularly between Lee and Baraka. The financial support for the film, coming from a large studio, and Lee's record of films that seemed too light-hearted, concerned Baraka and others, who

\footnotetext{
${ }^{210}$ Don Rojas, 'Sober Reflections', NYAN, 9 May 1992, p. 4; Sinclair, 'Thoughts on Rodney King', NYAN, 8 August 1992, p. 26; Charles Baillou, 'Endangered young Black males voice their demands of society', NYAN, 30 May 1992, p. 9.

${ }^{211}$ Daniels, 'The Rodney King Verdict: 'No Justice, No Peace', LAS, 21 May 1992, p. A7.

${ }^{212}$ Cecil Murray, quoted in Virgie Murray, 'Parishioners Seek Comfort in Various Churches', $L A S, 7$ May 1992, p. C6.

${ }^{213}$ Baillou, 'From Martin Luther King to Rodney King, racism still rampant', NYAN, 13 April 1991, p. 5.
} 
believed that Malcolm X should not be "trashed to make middle class Negroes sleep easier". ${ }^{214}$ Baraka's concerns highlighted that class differences within the AfricanAmerican community still existed, but rather than middle-class suspicion of Malcolm $\mathrm{X}$, it was now a case of middle-class African Americans potentially diluting his power and threatening poorer blacks' ownership of him.

Malcolm X was a box-office success, and further rehabilitated it's subject's reputation. Malcolm X's reputation had already undergone significant rehabilitation in the twentyseven years leading up to the film, but it reinforced the trend. Mainstream and black newspapers mentioned the film regularly throughout production, even occasionally putting it on the front page. ${ }^{215}$ Once released, the film generated even more publicity, and found its way onto even more front pages, mainstream as well as black. ${ }^{216}$ Most stories described the film's success, and the film's favourable reception in the AfricanAmerican community. ${ }^{217}$ Examining the reception of Malcolm X, mainstream newspapers gave little space to his critics, and referred to the controversies that Malcolm X caused during his lifetime while distancing themselves from the criticism. At the same time, the newspapers treated Malcolm X's ideas more positively.

Malcolm $X$ was the premier popular-culture event relating to King or Malcolm X since their deaths. King's appeal was of the kind that suited a nationally recognised hero and icon, but not the subject of a major Hollywood film. By contrast, mainstream culture had mainly left Malcolm X alone, and so Lee's film resulted in a rediscovery. Had the film been based on King, it could not have sparked the same excitement. Sinclair's comment in 1987, that King was basically so boring that he was unusable on screen, still applied. Too many people, from Reaganite dream-quoters, to black activists, had their own images of King, and their own expectations regarding those images being fulfilled. Regardless of the accuracy of their imaginings of King may have been,

\footnotetext{
${ }^{214}$ Evelyn Nieves, 'Malcolm X: Firestorm Over a Film Script', NYT, 9 August 1991, p. B1. 215 'Malcolm X: Firestorm Over a Film Script', NYT; 'Cosby, Magic, Oprah and Others Rescue Spike Lee's Malcolm X', LAS, 28 May 1992, p. A22; Herb Boyd, 'Will Malcolm X movie be premiered at the Apollo?', NYAN, 10 October 1992, p. 1.

${ }^{216}$ Boyd, 'Spike Lee does the right thing by Malcolm', NYAN, 14 November 1992, p. 1;

Wilkerson, 'Young Believe Malcolm X Is Still Speaking to Them', NYT, 18 November 1992, p. A1.

${ }^{217}$ Sheila Rule, 'Malcolm X: The Facts, the Fictions, the Film', NYT, 15 November 1992, p. H1; Lynette Holloway, 'On Rikers, MX \& Director Find Fans', NYT, 22 February 1993, p. B1.
} 
members of the public had an opinion, and so there were expectations as to how that might have gone. While previous stage productions had examined Malcolm X's life, the big-budget Hollywood film of Lee's making was certainly much more exciting for the public imagination. It also had the effect of cementing Malcolm X's position as an icon of popular culture, as opposed to the revered King.

Reflecting the more positive assessment, the mainstream press showed new appreciation for Malcolm X's prison conversion and personal growth. In 1993, the NYT discussed Malcolm X's learning to read in prison as a central lesson for the importance of literacy, and even published an article reporting a screening of Malcolm $X$ at a prison. ${ }^{218}$ In a feature on prisoner rehabilitation programs in the local area, the WP highlighted Malcolm X, King, and Thurgood Marshall as people whom the mostly black inmates could admire. ${ }^{219}$ Newspapers no longer used indicators of scepticism, such as the use of "he believed..." to preface any reference to Malcolm X's retelling of his father's death or the burning of his family's home in Nebraska, indicating that Malcolm X's retelling of his life carried more weight with the mainstream media than it had previously, and that Malcolm X was a more legitimate and acceptable figure. ${ }^{220}$

Newfound interest in Malcolm X's prison conversion helped him gain a favourable image from a group previously unsympathetic. Conservatives, otherwise unlikely to think highly of a black activist who had dismissed white people and denounced Christianity, found the former Malcolm Little's experience in turning his own life around through education and religion was a masterclass in the virtues of self-help and individual responsibility that they preached. Black conservative Supreme Court nominee Clarence Thomas claimed to be an ideological heir of Malcolm X, to the consternation of some of Thomas's opponents, such as Angela Davis. ${ }^{221}$ Even neoconservative WP columnist Charles Krauthammer expressed appreciation for

\footnotetext{
218 'When X = Literacy', NYT, 6 January 1993, p. A20; Lynette Holloway, 'On Rikers, 'Malcolm X' And Director Find Fans', NYT, 22 February 1993, p. B1.

${ }^{219}$ Marcia Greene, 'Trying to Turn a Life Away From Crime', WP, 12 December 1993, p. A1.

${ }^{220}$ See, for instance, Lloyd Rose, 'The Movie, The Myth \& The Man', WP, 22 November 1992. See also Lee, 'New Child Welfare Chief', NYT, 18 November 1990, p. 38, which states Little was "Murdered", and shares Malcolm X's suspicion that Little was murdered for his political activity, while still allowing for some doubt.

${ }^{221}$ David Margolick, 'Judge Portrayed as a Product Of Ideals Clashing With Life', NYT, 3 July 1991, p. A1; Angela Davis, 'Rope', NYT, 24 May 1992, p. E11.
} 
Malcolm X. Praising the original autobiography but not Lee's film, Krauthammer was unimpressed by what he considered to be the film's tendency to exult all three "stages" of Malcolm X's persona, rather than Krauthammer's preferred final stage. ${ }^{22}$ Krauthammer may have exaggerated his purported appreciation for Malcolm X's significance for rhetorical effect, but nonetheless it remains significant that such a publicly identified conservative intellectual could show positive interest in Malcolm X, rather than simply dismissing him.

The unprecedented extent of Malcolm X's new appeal meant a new representation of the relationship between him and King. Over the period of the 1980s and 1990s, newspapers defined not just what King and Malcolm X represented, but also whom they represented. Mainstream newspapers never treated Malcolm X as a hero-type figure for European Americans, but instead as a figure valuable for his positive contribution for African Americans. The mainstream rethinking of Malcolm X did not lead them to claim Malcolm $\mathrm{X}$ as a universal figure, however, and his significance was limited to the black community. In a way, this represented the best explanation of their significance. While both men were now part of the same movement, they were assigned different roles within it. One sought to unify blacks and whites to end racial inequality. The other sought to motivate and empower blacks to achieve the same goal.

The black press continued to regard both King and Malcolm X primarily in terms of each man's contributions to the black community. Focusing on their value to African Americans led the black press to see King and Malcolm X as equally important, and as models that African Americans could follow simultaneously. King's only big advantage, for the black press, was that he had the additional advantage of being accepted and admired by the white community as well. The concerns of Baraka and others about Malcolm X's newfound popularity were lent a little credence by the increased mainstream appreciation for him, especially when coming from conservatives, but as the as the hype from Malcolm $X$ dissipated, the mainstream media stopped talking about Malcolm X so much, and he remained a predominantly black figure.

${ }^{222}$ Charles Krauthammer, 'Patronizing Malcolm X', WP, 27 November 1992, p. A31. 


\section{Conclusion}

A period that began with the first observation of Martin Luther King Day encompassed minor smears against King's character, race riots, and a Malcolm X film, demonstrated that the United States had still to overcome its racist past. It took death and distance from the 1960s for the media to repackage King and Malcolm X. Newspapers appreciated convergence between King and Malcolm X politically, but this did not extend to convergence of personalities. After death, King and Malcolm X had garnered more positive media images. King became a respected figure in American political memory, and even someone like Reagan could not afford to distance himself by the 1980s. Although the media sanctified King, sometimes at the expense of analysing his worldview, they sometimes discussed his Vietnam opposition and campaign against poverty positively, which had not always been the case. For Malcolm X, the transformation was even greater. The black press praised his memory wholeheartedly. Feature articles in the $N Y T$ and other mainstream papers examined the nuances of his worldview in unprecedented depth. Journalists used him as a source for a favourable comparison, clearly assuming that the reader would also find Malcolm $\mathrm{X}$ a praiseworthy figure. However, King and Malcolm X's personas remained distinct in the mainstream press, and they provided alternative comparisons for future black public figures. 


\section{Conclusion}

The changing public images of Martin Luther King and Malcolm X illustrate contrasting representations of African Americans more generally, as Barack Obama discovered throughout his presidential campaign. A large part of Obama's initial appeal had been the fact that his political power was not based exclusively on the African-American community. In private, Democratic Senate Majority Leader Harry Reid remarked that Obama would make a good candidate for his party, in part because he was "light-skinned... with no Negro dialect, unless he wanted to have one."223 Unsurprisingly, Reid had to apologise for his remarks when they were eventually publicised. His comments, however, praised something that Obama's black critics had already noted less favourably. Some members of the African-American community thought Obama was acting "too white", not appropriate for someone who could be America's first black president. ${ }^{224}$ King's former associate Jesse Jackson, also a two-time presidential candidate, agreed, criticising Obama for "talking down" to black voters in an effort to win white votes. ${ }^{225}$ As part of counteracting these criticisms, Obama needed to place himself within a broader past tradition of AfricanAmerican leadership that would also seem acceptable to whites.

Drawing on a wider history of black leadership necessarily raised questions about the black protest movement and the legacies and influences of King and Malcolm X. The legacy of Malcolm X, a Muslim, proved to be particularly problematic after the September 11 attacks on New York City and Washington, D.C., and the subsequent Islamophobia. The most visible illustration of fears surrounding Obama's race came with a cover of New Yorker magazine in July 2008, which depicted Barack and Michelle Obama in the Oval Office. In the cartoon, the Obamas had hung a portrait of Osama bin Laden and burned the American flag in the fireplace. While Barack

\footnotetext{
${ }^{223}$ Chris Cillizza, 'Majority Leader Reid apologizes to Obama for 2008 remarks', WP, 10 January 2010, http://www.washingtonpost.com/wpdyn/content/article/2010/01/09/AR2010010902141.html, accessed 3/6/13.

${ }^{224}$ See, for instance, Michael Fletcher, 'Obama's Appeal to Blacks Remains an Open Question', WP, accessed online, http://www.washingtonpost.com/wpdyn/content/article/2007/01/24/AR2007012402032.html, accessed 20/6/13; Ta-Nehisi Paul Coates, 'Is Obama Black Enough?', Time, 1 February 2007, http://www.time.com/time/nation/article/0,8599,1584736,00.html, accessed 3/6/13. ${ }^{225}$ Jeff Zeleny, 'Jesse Jackson Apologizes For Remarks On Obama', NYT, 10 July 2008, p. A18.
} 
Obama wore the white robes of an Islamic mullah, Michelle Obama, sporting an Afro hairstyle and a gun, resembled Black Power activist Angela Davis. The article caused an immediate outcry. Both Obama and his rival, John McCain, denounced the image, and cable news networks wrangled over how racist the image was. Lost in the sound and fury was the fact that the New Yorker was trying to mock pre-existing fears about Obama's race. Faced with such an environment, some whites fearing his apparent radicalism and some blacks resenting his efforts seem acceptable to whites, Obama could not betray a hint of radicalism, but nor could he deny his racial identity.

No one would ever accuse Malcolm X of being insufficiently black, but he was an unsuitable role model for a presidential campaign. Although the New Yorker did not directly invoke his name, Malcolm X's Muslim religion and his association with violence and anti-white rhetoric remained visible in the fears surrounding Obama's race. Although mainstream newspapers had rehabilitated Malcolm X by 2008, he still represented a less acceptable side of black politics for someone trying to be president of the United States. His significance lay primarily in his appeal for African Americans, to whom he provided a model of leadership untainted by mainstream appropriation.

King provided a figure with whom Obama could identify to gain popular appeal. Speeches like 'A More Perfect Union' positioned Obama as the heir to the civil rights movement, someone whose candidacy was possible only because of the changes that King had wrought. Whether one considered the black protest movement complete or otherwise, Obama's position as its heir counted in his favour. Those who thought the battle fought and won could view Obama's election as the symbolic realisation of King's "dream". Those who regarded the movement as unfinished could hope that, as King's successor, Obama would continue the movement's work. Obama continued to identify with King once in office, allowing himself to be photographed on the bus on which Rosa Parks precipitated the Montgomery bus boycott by refusing to stand for a white passenger, a photograph that circulated heavily online. ${ }^{226} \mathrm{He}$ further aligned himself with King by speaking at the dedication of the memorial to King on the National Mall in 2011, a monument that placed King physically and politically

${ }^{226}$ The White House, http://www.whitehouse.gov/photos-and-video/photo/2012/04/presidentbarack-obama-sits-famed-rosa-parks-bus, accessed 3/6/13. 
between Thomas Jefferson and Abraham Lincoln. ${ }^{227}$ King remained the paramount icon for African Americans seeking public office, while Malcolm X was a more unsettling figure associated with black radicalism.

This thesis has argued that the dichotomy between King and Malcolm X stemmed from a misunderstanding of the worldviews of both men. Consider King's most famous speech. "I have a dream" contained a stirring reaffirmation of American ideals, to be sure, but it also equated the brutality of Jim Crow to discrimination within Northern cities. As if that was not enough, King also threatened a revolution to "shake the foundations" of American society and insisted on immediate, rather than gradual, equality for African Americans. Furthermore, this was King at the apex of his popularity with mainstream America, before he became increasingly disillusioned with the slow rate of racial progress. ${ }^{228}$ While King in his later years lost faith in the capacity of white Americans to solve racial inequality, Malcolm X seemed to gain it. Moving beyond separatism, he had publicly claimed the goal of racial unity. Even before leaving the Nation of Islam, Malcolm $\mathrm{X}$ demonstrated signs of increased tolerance for white Americans. Further, in spite of Malcolm X's rhetoric, he never actually led or incited a race riot. Although he did not believe in nonviolence, Malcolm X insisted that his followers adhere to the law. The American media, however, did not come to terms with these subtleties and continues to depict them as a choice, albeit in a more nuanced fashion than they once did.

This thesis helps explain why the contrasting images of King and Malcolm X persist. Chapter One demonstrated that the associations with nonviolence and violence were crucial in shaping King and Malcolm X's public image, and their public relationship within the black protest movement. By representing King and Malcolm X as rivals, newspapers were able to endorse King's leadership and reject Malcolm X's. After they died, as Chapter Two has shown, all newspapers studied immediately mourned the loss of King's leadership, in contrast to the much more subdued response to Malcolm X's death, and reinforced a distinction between them as saintly crusader

\footnotetext{
${ }^{227}$ Barack Obama, 'Remarks by the President at the Martin Luther King, Jr. Memorial Dedication', The White House, www.whitehouse.gov/the-press-office/2011/10/16/remarkspresident-martin-luther-king-jr-memorial-dedication, accessed 10/3/12.

${ }_{228}^{28}$ Martin Luther King, Jr., "I have a dream", 28 August 1963, BBC, http://news.bbc.co.uk/2/hi/americas/3170387.stm, accessed 3/6/13.
} 
against Southern racism and angry militant. Chapter Three discussed the mainstream press's rediscovery of Malcolm X, which granted Malcolm X legitimacy but continued to represent King and Malcolm $\mathrm{X}$ as different personalities with different areas of significance.

The introduction noted the sluggishness of both the black and the mainstream press to revise the frames of reference with which they represented King and Malcolm X. In the years after their deaths, King was immediately sanctified and revered, but placed primarily within the context that made newspapers most comfortable: leading a nationwide black protest movement for black newspapers, and leading a regional civil rights movement for mainstream ones. Malcolm X's murder was generally greeted as lamentable only because newspapers opposed political violence, and not because they mourned Malcolm X's leadership. After a period of relative obscurity, newspapers became more willing to discuss Malcolm X's worldview, but he remained much more significant to black than to white Americans. King remained a figure of universal significance, someone against whom criticism could scarcely be broached. By the end of the period covered, mainstream newspapers no longer delegitimised Malcolm X's ideas, but they generally explained his importance in terms of his value to African Americans.

In presenting his own public image as an African-American presidential candidate, Obama has negotiated these two rival images of black political leaders; demonstrating race is still an important factor in American politics. Obama's election was hailed by some as the realisation of King's "dream", or, as the NYT claimed, the end of the "racial barrier". ${ }^{229}$ The fact that racially based fears gave Obama such a limited choice of black figures with which to associate shows these claims were premature. If Obama's election really had ushered in a post-racial era for American politics, he would not have had to choose between King and Malcolm X, as black anger would not have been such an uncomfortable topic for the mainstream media. Rather, Obama's dilemma indicates that there is still little room for anger or militancy from a black public figure trying to appeal to a mainstream American audience.

${ }^{229}$ Adam Nagourney, 'Obama: Racial Barrier Falls in Decisive Victory', NYT, 5 November 2008, p. A1. 


\section{Bibliography}

\section{Primary Sources}

\section{$\underline{\text { Books }}$}

King, Martin Luther, The Papers of Martin Luther King Volume VI: Advocate of the Social Gospel, September 1948- March 1963, ed. Clayborne Carson, (Berkeley, University of California Press, 2007).

X, Malcolm, with Alex Haley, The Autobiography of Malcolm X (London, Penguin Books, 1968).

\section{ProQuest Historical Newspapers}

\section{Atlanta Daily World (ADW)}

‘A Timely Honor for Dr. King’, $A D W, 15$ January 1971, p. 4.

‘A Date With Destiny', $A D W, 4$ November 1980, p. 6.

'A King Holiday?', $A D W, 29$ September 1983, p. 4

'Birthday Issue Brings Debate', $A D W, 9$ October 1983, p. 4

Portia Scott, 'King Historic Holiday Jan. 20’, ADW, 19 January 1986, p. 1.

'Nonviolence Remains the Main Challenge!', $A D W, 18$ January 1987, p. 4.

'Peace With Freedom Remains The Top Goal', $A D W, 15$ January 1989, p. 4.

'Co-Hosts Of "Living The Dream”: A Tribute to Dr. M.L. King, Jr.', $A D W, 17$

January 1989, p. 1.

Scott \& Della Pulliam, 'Celebration Of King’s Birth Grows In Numbers,

Tributes', $A D W, 14$ January 1990, p. 1.

Angela Chamblee, 'The Image Of Malcolm X In Popular Culture Today', $A D W$, 12 November 1992, p. 13.

Chicago Defender $(C D)$

'Home Of Malcolm X Is Fire-Bombed; No Injuries', CD, 15 February 1965, p. 3. 
'Malcolm X Killed At N. Y. Meeting', CD, 22 February 1965, p. 1.

'Dr. King's Politics', CD, 24 August 1967, p 17.

\section{Los Angeles Sentinel (LAS)}

'A New Kind of Negro Leader', LAS, 31 October 1957, p. C7.

'Ministers Disown Muslims', LAS, 24 May 1962, p. A1.

'Malcolm X Scores Metros Trial Stories', LAS, 29 November 1962, p. A2.

'Saluting LBJ', LAS, 21 January 1965, p. A6.

George Goodman, 'Malcolm X Vendetta Threatens Violence', LAS, 25 February 1965, p. A1.

'Bedfellows', LAS, 21 December 1967, p. A6.

Bill Lane, "I Have Discovered That The Highest Good Is Love", LAS, 11 April 1968, p. A5.

‘Time for Realism', LAS, 18 April 1968, p. A6.

'A National Holiday for MLK', LAS, 8 April 1971, p. A6.

'King Holiday', LAS, 11 January 1973, p. A6.

'A Shrine for a Hero', $L A S, 5$ April 1976, p. A6.

'The Shame of It', LAS, 13 December 1979, p. A6.

'A Needed Tribute', LAS, 15 January 1981, p. A6.

Janis Wilkins-Mash, 'The Legacy of Malcolm X', LAS, 17 May 1986, p. 13.

'Birthday of Malcolm X Observed', LAS, 19 May 1988, p. A11.

Alan Bell, 'Spike Lee Does The 'Rite' Thing', LAS, 29 June 1989, p. B8.

Ron Dungee, 'M.L.K. 'Assassinated' By Closest Friend', LAS, 19 October 1989, p. A1.

Ron Daniels, 'Protecting The Legacy Of Martin Luther King', LAS, 11 January 1990, p. A6.

Larry Aubry, 'Eyes On The Problem', LAS, 1 March 1990, p. A7.

'Malcolm X Observed', LAS 17 May 1990, p. C11.

'Hail to the King', LAS, 17 January 1991.

'A Time for Healing Wounds', LAS, 13 June 1991, p. A6.

'The Prophetic Vision of Martin Luther King, Jr.', LAS, 16 January 1992, p. A7. 'L.A. Celebrates Life of Dr. King', LAS, 23 January 1992, p. A1.

'MX Would Be Appalled By Some Youths Today', LAS, 5 March 1992, p. A1. 
Virgie Murray, 'Parishioners Seek Comfort in Various Churches', LAS, 7 May 1992, p. C6.

Daniels, 'The Rodney King Verdict: 'No Justice, No Peace’, LAS, 21 May 1992, p. A7.

'Cosby, Magic, Oprah and Others Rescue Spike Lee's Malcolm X', LAS, 28 May 1992, p. A22.

Sheila Rose, 'What Malcolm X Means To Me', LAS, 19 November 1992, p. B6.

'White Press Gets \$ 'From 'Malcolm X', LAS, 24 December 1992, p. A2.

\section{Los Angeles Times (LAT)}

'Muslim Hatred Called Threat to Community', LAT, 7 May 1962, p. 32.

'The Muslim Incident: Two Juries Investigate', LAT, 20 May 1962, p. F5.

'Negro Rally Demands End to Police 'Brutality', LAT, 21 May 1962, p. 2.

'Yorty Assails Boast of Black Muslim Chief', LAT, 7 June 1962, p. A1.

'Racial Violence Assailed by Dr. Luther King', LAT, 16 June 1962, p. 11.

'Top New York Muslim Says L.A. Is on Trial', LAT, 4 May 1963, p. 8.

'Malcolm X Gunned Down', LAT, 22 February 1965, p. 1.

Robert Kirsch, 'The Real and Imagined Faces of Malcolm X', LAT, 5 November 1965, p. C6.

Nicholas C. Chriss \& Jack Nelson, 'Dr. King Slain by Sniper in Memphis', LAT, 5 April 1968, p. 1.

'Assassination of Dr. King', LAT, 7 April 1968, p. K4.

'A Crossroads in U.S. History', LAT, 7 April 1968, p. K6.

'More Than a Dream', LAT, 20 January 1986, p. 4.

Janny Scott, 'King Parade Puts Best Foot Forward Downtown', LAT, 18 January 1987, p. SD A1.

'Much to Cheer, Much to Do', LAT, 18 January 1988, p. C6.

'Progress \& Promise', LAT, 4 April 1988, p. C6.

Debra Behr, 'A Dream to Remember', LAT, 13 January 1989, p. B1.

Charles Hillinger, 'King Site Honors His Memory’, LAT, 15 January 1989, p. 116.

Mark Smith, 'King and Malcolm X Take a 'Meeting', LAT, 23 February 1989, p. D10. 
Jack Mathews, 'Controversial Film for a Long Hot Summer', LAT, 22 May 1989, p. E1.

Sheila Benson, 'Spike Lee Comes of Age', LAT, 30 June 1989, p. J1D.

'How Long, America?', LAT, 21 January 1991.

Lucille Renwick, 'Is the Dream Still Alive?', LAT, 17 January 1993, p. 3.

\section{New York Amsterdam News (NYAN)}

James Booker, 'Who is Martin Luther King?', NYAN, 31 March 1956, p. 2.

'Mr. Malcolm X At New York Temple Sunday', NYAN, 5 January 1957, p. 3.

'Moslems Hurl Charges at State Prison Rule', NYAN, 7 November 1959, p. 1.

'Muslims Say: "Welcome” to Probe!', NYAN, 25 August 1962, p. 1.

Les Matthews, "Muslim Calls U.S. "A Police State”, NYAN, 23 February 1963, p. 1.

'Malcolm X Flees for Life; Muslim Factions at War', NYAN, 20 June 1964, p. 1.

““Steady, Eddie!”, NYAN, 27 February 1965, p. 1.

'Someone Said ...', NYAN, 13 March 1965, p. 10.

'We Are Overcoming', NYAN, 20 March 1965, p. 1.

'Where We Stand', NYAN, 15 April 1967, p. 1.

‘American Tragedy', NYAN, 6 May 1967, p. 14.

Cathy Aldridge, 'Black, White Came to Bury Martin Luther King, Jr.', NYAN, 13 April 1968, p. 1.

'He Was a MAN', NYAN, 13 April 1968, p. 20.

'After the Eulogies', NYAN, 20 April 1968, p. 16.

'The Path Of Reason', NYAN, 4 January 1969, p. 1.

'Discrediting Dr. King', NYAN, 3 June 1978, p. A4.

'The end of Dr. King's dream?', NYAN, 5 August 1978, p. A4.

'Martin Luther King Jr.', NYAN, 12 January 1980, p. 10.

'Does Reagan Require a New Martin?', NYAN, 16 January 1982, p. 10.

William Seraile, 'Hypocrisy of New York Times', NYAN, 25 December 1982, p. 13.

'Leaders... Choose someone', NYAN, 9 February 1985, p. 14.

'Widow, 2 others get Malcolm X awards', NYAN, 25 May 1985, p. 9. 
Browne, Zamgba, 'New York ready for King’s Day', NYAN, 17 January 1987, p. 25.

Abiola Sinclair, 'Malcolm X and King duel', NYAN, 18 April 1987, p. 23.

Harold L. Jamison, 'King remembered in Harlem program', NYAN, 23 January 1988, p. 10.

'Martin would have laughed... and cried', NYAN, 21 January 1989, p. 12.

Sinclair, 'Do the Right Thing' - summer's best', NYAN, 1 July 1989, p. 30.

Elizabeth Green, 'Spike Lee 'Does Bed-Stuy Right'’, NYAN, 8 July 1989, p. 19.

Browne, 'Activists lash out at Rev. Abernathy's memoirs', NYAN, 21 October 1989, p. 38.

Greg Harris, ‘Abernathy's memoirs', NYAN, 21 October 1989, p. 40.

Benjamin Chavis, 'Eyes on the Prize: Part Two', NYAN, 6 January 1990, p. 13.

Doug Henderson, ‘After 25 years Malcolm X is back', NYAN, 9 June 1990, p. 15.

Sinclair, 'Martin Luther King Jr. and the plagiarism charges', NYAN, 1 December 1990, p. 24.

Feddoes, Sadie, 'City ready for Martin Luther King Day gala', NYAN, 19 January 1991, p. 18.

'Happy Birthday Martin!!: A time to break silence', NYAN, 19 January 1991, p.

27.

Charles Baillou, 'From Martin Luther King to Rodney King, racism still rampant', NYAN, 13 April 1991, p. 5.

Sinclair, 'Thoughts on Rodney King', NYAN, 8 August 1992, p. 26.

Don Rojas, ‘Sober Reflections', NYAN, 9 May 1992, p. 4.

Baillou, 'Endangered young Black males voice their demands of society', NYAN, 30 May 1992, p. 9.

Herb Boyd, 'Will Malcolm X movie be premiered at the Apollo?', NYAN, 10

October 1992, p. 1.

Boyd, 'Spike Lee does the right thing by Malcolm', NYAN, 14 November 1992, p. 1.

\section{New York Times (NYT)}

'Battle Against Tradition', NYT, 21 March 1956, p. 28

George Barrett, 'Montgomery: Testing Ground', NYT, 16 December 1956, p. 48. 
Barrett, 'Jim Crow, He's Real Tired', NYT, 3 March 1957, p. 11.

'Moratorium on Atom Bomb Tests Asked by 140 Protestant Leaders', NYT, 21 April 1958, p. 1.

Michael Clark, 'Rise in Racial Extremism Worries Harlem Leaders', NYT, 25

January 1960, p. 18.

'Muslim Talk Approved', NYT, 23 November 1961, p. 50.

'Muslim Charges Englewood Sham', NYT, 6 August 1962, p. 27.

Gertrude Samuels, 'Two Ways: Black Muslim and N.A.A.C.P.', NYT, 12 May 1963, p. SM14.

M.S. Handler, 'Malcolm X Scores JFK on Racial Policy', NYT, 17 May 1963, p. 14.

'Malcolm X Assails Racial Integration', NYT, 14 July 1963, p. 50.

'Malcolm X scores U.S. and Kennedy', NYT, 2 December 1963, p. 21.

R. W. Apple Jr., 'Malcolm X Silenced for Remarks On Assassination of

Kennedy', NYT, 5 December 1963, p. 22.

John Herbers, 'Critical Test for the Nonviolent Way', NYT, 5 July 1964, p. SM5.

Peter Kihss, 'Malcolm X Shot to Death at Rally Here', NYT, 22 February 1965, p. 1.

Gay Talese, 'Police Save Suspect From the Crowd', NYT, 22 February 1965, p.

10.

Douglas Robinson, 'Rights Leaders Decry 'Violence', NYT, 22 February 1965, p. 11.

'Malcolm X', NYT, 22 February 1965, p. 20.

'Black Power Is Black Death', NYT, 7 July 1966, p. 35.

'The Politics of Frustration', NYT, 7 August 1966, p. 158.

'Dr. King's Error', NYT, 7 April 1967, p. 36.

'What Do the Negroes Want?', NYT, 19 November 1967, p. 21.

'Racism in the Schools', NYT, 23 February 1968, p. 32.

'Mini-Riot in Memphis', NYT, 30 March 1968, p. 32.

Murray Schumach, 'Martin Luther King Jr.: Leader of Millions in Nonviolent

Drive for Racial Justice', NYT, 5 April 1968, p. 28.

“"The Need of All Humanity”, NYT, 5 April 1968, p. 46.

James T. Wooten, 'Malcolm X University to Open In Durham as Militants'

School', NYT, 28 October 1969, p. 44. 
B. Drummond Ayres Jr., 'Georgia to Hang Dr. King Portrait', NYT, 5 January 1974, p. 25.

'Dr. King's Holiday', NYT, 15 January 1975, p. 42.

'Inciting Suicide', NYT, 21 November 1975, p. 42.

'How to Remember Martin Luther King', NYT, 10 December 1982, p. A34.

'A Day for Martin Luther King', NYT, 11 October 1983, p. A30.

'Not a 35-Year Question', NYT, 21 October 1983, p. A34.

'U.S. Reflects on Dream of a Battler for Rights', NYT, 16 January 1985, p. B3.

'In Music, Readings and Film, Salutes to Dr. King', NYT, 17 January 1986, p. C28.

Gerald Fraser, 'Stage: Duane Shepard As 'Brother Malcolm X', NYT, 8 June 1986, p. 74.

Howell Raines, 'Driven to Martyrdom', NYT, 30 November 1986, p. 360.

'How to Overcome', NYT, 19 January 1987, p. A16.

‘After 20 Years, Fair Housing Teeth', NYT, 8 August 1988, p. A16.

Ari Goldman, 'A Day Off Is Not the Dream, Disciple of King Says', NYT, 16 January 1989, p. A1.

Walter Goodman, 'An Imaginary Meeting of Dr. King and Malcolm X', NYT, 3

May 1989, p. C26.

“'Do the Right Thing': Issues and Images', NYT, 9 July 1989, p. H1.

Goodman, 'Recalling the Pursuit of a Still-Elusive Prize', NYT, 15 January 1990, p. C11.

Gerald Fraser, 'The Voice of Malcolm X Has an Audience Again', NYT, 20

February 1990, p. B3.

Brooklyn's Exceptional Preacher', NYT, 30 June 1990, p. 22.

Anthony De Palma, 'Plagiarism Seen by Scholars In King’s Ph.D. Dissertation', NYT, 10 November 1990, p. 1.

'What Dr. King Wrote, and What He Did', NYT, 13 November 1990, p. A30.

Felicia Lee, 'New Child Welfare Chief', NYT, 18 November 1990, p. 38.

'Martin Luther King's Moral Authority', NYT, 12 January 1991, p. A16.

'A Better Way to Honor MLK', NYT, 26 April 1991, p. A28.

David Margolick, 'Judge Portrayed as a Product Of Ideals Clashing With Life', NYT, 3 July 1991, p. A1. 
Evelyn Nieves, 'Malcolm X: Firestorm Over a Film Script', NYT, 9 August 1991, p. B1.

Jason Deparle, 'The Civil Rights Battle Was Easy Next to the Problems of the Ghetto', NYT, 17 May 1992, p. E1.

Angela Davis, 'Rope', NYT, 24 May 1992, p. E11.

Sheila Rule, 'MX: The Facts, the Fictions, the Film', NYT, 15 November 1992, p. H1.

Isabel Wilkerson, 'Young Believe MX is Still Speaking to Them', NYT, 18 November 1992, p. A1.

'Hostility Greets Students at Black School in White Area of Detroit', NYT, 2

December 1992, p. B12.

'When X = Literacy', NYT, 6 January 1993, p. A20.

Lynette Holloway, 'On Rikers, MX \& Director Find Fans', NYT, 22 February 1993, p. B1.

Jeff Zeleny, 'Jesse Jackson Apologizes For Remarks On Obama', NYT, 10 July 2008, p. A18.

Adam Nagourney, 'Obama: Racial Barrier Falls in Decisive Victory', NYT, 5

November 2008, p. A1.

\section{Washington Post (WP)}

Wallace Terry, ‘A ‘Messiah' Preaches Hate of White Man to 70,000 ‘Black Muslims", WP, 11 December 1960, p. E3.

Terry, 'Black Muslim Elijah's Lowly Start', WP, 12 December 1960, p. A3.

Terry, 'Injustices Stressed for Black Muslims', WP, 13 December 1960, p. B3.

Terry, 'Members Face Rigid Tests In Joining Black Muslims', WP, 14 December 1960, p. B8.

Terry, 'Black Muslims Told They're 'Chosen People', WP, 15 December 1960, p. B12.

Terry, 'Black Muslims’ Hate Campaign Criticized', WP, 16 December 1960, p. A18.

Dave Brady, 'Patterson 'Wises up' Black Muslim Clay', WP, 15 March 1964, p. C5. 
Steven Gerstel, 'Negro Leaders Plan Immediate Test of Rights Bill', WP, 20 June 1964, p. A12.

Ramon Geromia, 'Victim Known as Articulate Leader', WP, 22 February 1965, p. A3.

'Assassination', WP, 23 February 1965, p. A16.

'King Offers to Mediate in Black Nationalist Feud', WP, 1 March 1965, p. A2.

'From Here to Infinity', WP, 14 August 1965, p. A10.

‘A Tragedy', WP, 6 April 1967, p. A20.

'King’s Camp-In', WP, 26 October 1967, p. A20.

Willard Clopton Jr., 'Unity Reigns In Campaign', WP, 4 April 1968, p. C1.

'Dr. King, Apostle of Nonviolence, Drew World Acclaim', WP, 5 April 1968, p. A12.

'Martin Luther King Jr.', WP, 6 April 1968, p. A12.

'Student Walkouts Honor Malcolm X', WP, 22 February 1969, p. A3.

Nicholas von Hoffman, 'Malcolm Lives', WP, 1 December 1969, p. C1.

Adam Shaw, 'Many in City Note Dr. King Birthday', WP, 16 January 1974, p.

C1.

'The FBI and Martin Luther King', WP, 4 May 1976, p. 18.

'Remembering Martin Luther King Jr.', WP, 15 January 1981, p. A18.

Juan Williams \& Margaret Shapiro, 'President Criticized for King Statement', WP, 21 October 1983, p. A3.

Martin Weil, 'Martin Luther King Sr., 84, Dies', WP, 12 November 1984, p. B6.

'Martin Luther King Sr.', WP, 13 November 1984, p. 14.

Joseph McLellan, ' $X$ ': Opera as History', WP, 13 October 1985, p. D1.

Susan Schmidt, 'Martin Luther King III: Keeping Father's Dream', WP, 13

January 1986, p. B4.

'Selma Council Votes Holiday to Honor King', WP, 16 January 1986, p. A10.

'The King Holiday', WP, 20 January 1986, p. A18.

Dorothy Gilliam, 'Different Era, Same Arrogance', WP, 4 December 1986, p. B3.

'Dr. King's Day', WP, 19 January 1987, p. A17.

Patrice Gaines-Carter, ‘Va. Students Learn King’s Lesson’, WP, 16 January 1989, p. A6.

'Gains to Be Made...', WP, 16 January 1989, p. A20.

'Spike Lee's Cannes Shake-Up', WP, 22 May 1989, p. B1. 
Amy Schwartz, 'Spike Lee Sees a Terrible Thing', WP, 8 August 1989.

Patricia Brennan, 'Henry Hampton, Still Telling America's Story of Civil Rights', WP, 14 January 1990, p. 9.

Lynda Richardson, 'Remembering a Man and His Enduring Legacy', WP, 22

February 1990, p. D3.

Elizabeth Castor Washington, 'Whatever Happened to the Hero?', WP, 20 June 1990, p. C1.

Pamela Sommers, “Meeting': Malcolm \& King Collide', WP, 14 September 1990, p. C4.

Dan Balz, 'Scholars Question Portions Of King's Academic Papers', WP, 10

November 1990, p. A1.

David Garrow, 'How King Borrowed', WP, 18 November 1990, p. C1.

'Dr. King's Enduring Message', WP, 21 January 1991, p. A20.

Lynne Duke, 'Malcolm X as Teacher', WP, 19 November 1992, p. A1.

Lloyd Rose, 'The Movie, The Myth \& The Man', WP, 22 November 1992.

Charles Krauthammer, 'Patronizing Malcolm X', WP, 27 November 1992, p. A31. Marcia Greene, 'Trying to Turn a Life Away From Crime', WP, 12 December 1993, p. A1.

\section{Speeches}

Carter, Jimmy, 'Presidential Medal of Freedom Remarks on Presenting the Medal to Dr. Jonas E. Salk and to Martin Luther King, Jr.', 11 July 1977, The American Presidency Project, http://www.presidency.ucsb.edu/ws/index.php?pid=7784, accessed 27/6/13.

King, Martin Luther, Jr., 'Address to 1st Montgomery Improvement Association Mass Meeting', 5 December 1955, Martin Luther King, Jr. Research and Education Institute, http://mlkkpp01.stanford.edu/index.php/kingpapers/article/address_to_first_montgomery_i mprovement_association_mia_mass_meeting_at_hol/, accessed 19/6/13.

King, "I have a dream", 28 August 1963, BBC, http://news.bbc.co.uk/2/hi/americas/3170387.stm, accessed 3/6/13. 
King, 'Nobel Prize Acceptance Speech', 10 December 1964, Official Web Site of the Nobel Prize,

http://www.nobelprize.org/nobel_prizes/peace/laureates/1964/kingacceptance_en.html, accessed 21/1/13.

King, 'Beyond Vietnam: A Time to Break Silence', 4 April 1967, Martin Luther King, Jr. Research and Education Institute, http://mlkkpp01.stanford.edu/kingweb/publications/speeches/Beyond_Vietnam.pdf, accessed 26/1/13.

Obama, Barack, 'A More Perfect Union', 18 March 2008, American Rhetoric, http://www.americanrhetoric.com/speeches/barackobamaperfectunion.htm, accessed 13/6/13.

Obama, 'Remarks by the President at the Martin Luther King, Jr. Memorial Dedication', The White House Web Site, www.whitehouse.gov/the-pressoffice/2011/10/16/remarks-president-martin-luther-king-jr-memorial-dedication, accessed 10/3/12.

Reagan, Ronald, 'Radio Address to the Nation on the Anniversary of the Birth of Martin Luther King, Jr.', 15 January 1983, The American Presidency Project, http://www.presidency.ucsb.edu/ws/index.php?pid=41387\#ixzz1 sWqiebL9, accessed 3/6/13.

\section{Websites}

Chris Cillizza, 'Majority Leader Reid apologizes to Obama for 2008 remarks', WP, 10 January 2010, http://www.washingtonpost.com/wpdyn/content/article/2010/01/09/AR2010010902141.html, accessed 3/6/13.

Ta-Nehisi Paul Coates, 'Is Obama Black Enough?', Time Magazine, 1 February 2007, http://www.time.com/time/nation/article/0,8599,1584736,00.html, accessed $3 / 6 / 13$. 
Michael Fletcher, 'Obama’s Appeal to Blacks Remains an Open Question', WP, accessed online, http://www.washingtonpost.com/wpdyn/content/article/2007/01/24/AR2007012402032.html, accessed 20/6/13

Roland Martin, 'The full story behind Rev. Jeremiah Wright's 9/11 sermon', CNN, 21 March 2008, http://ac360.blogs.cnn.com/2008/03/21/the-full-storybehind-rev-jeremiah-wrights-911-sermon/, accessed 3/6/13.

Martin, 'The full story behind Wright's “God Damn America” sermon', CNN, 21 March 2008, http://ac360.blogs.cnn.com/2008/03/21/the-full-story-behindwright $\%$ E2\%80\%99s-\%E2\%80\%9Cgod-damn-america\%E2\%80\%9D-sermon/, accessed 3/6/13.

The White House, http://www.whitehouse.gov/photos-andvideo/photo/2012/04/president-barack-obama-sits-famed-rosa-parks-bus, accessed 3/6/13. 


\section{Secondary Sources}

\section{Books}

Branch, Taylor, Parting the Waters: America in the King Years, 1954-1963 (New York, Simon \& Schuster, 1988).

Branch, Pillar of Fire: America in the King Years 1963-65 (New York, Simon \& Schuster, 1999)

Carson, Clayborne, In Struggle: SNCC and the Black Awakening of the 1960s

(Cambridge, Harvard University Press, 1981).

Carson (ed.), The Autobiography of Martin Luther King, Jr. (London, Little, Brown, 1999)

Cone, James H., Malcolm \& Martin \& America: A Dream or a Nightmare (Maryknoll, Orbis Books, 1991).

Dyson, Michael Eric, Making Malcolm: The Myth and Meaning of Malcolm X (Oxford, Oxford University Press, 1995).

Dyson, I May Not Get There With You: The True Martin Luther King, Jr. (New York, Touchstone, 2001).

Frazier, Franklin, Black Bourgeoisie (New York, The Free Press, 1957).

Gans, Herbert, Deciding What's News: a study of CBS evening news, NBC nightly news, Newsweek and Time (London, Constable, 1979).

Garrow, David, The FBI and Martin Luther King, Jr.: From "Solo” to Memphis (New York, W. W. Norton, 1981). 
Garrow, Bearing the Cross: Martin Luther King, Jr., and the Southern Christian Leadership Conference (New York, Vintage Books, 1986).

Jackson, Thomas, From Civil Rights to Human Rights: Martin Luther King, Jr., and the Struggle for Economic Justice (Philadelphia, University of Pennsylvania Press, 2007).

Lentz, Richard, Symbols, the News Magazines, and Martin Luther King (Baton Rouge, Louisiana State University Press, 1990).

Marable, Manning, Malcolm X: A Life of Reinvention (New York, Penguin Books, 2011).

Meriwether, James, Proudly We Can Be Africans: Black Americans and Africa, 1935-1961 (Chapel Hill, The University of North Carolina Press, 2002).

Oates, Stephen, Let the Trumpet Sound: The Life of Martin Luther King, Jr. (New York, Harper \& Row, 1982).

Paletz, David, \& Entman, Robert, Media Power Politics (New York, The Free Press, 1981).

Pride, Armistead S., \& Wilson II, Clint C., A History of the Black Press (Washington, D.C., Howard University Press, 1997).

Roberts, Gene, \& Klibanoff, Hank, The Race Beat: The Press, the Civil Rights Struggle, and the Awakening of a Nation (New York, Alfred A. Knopf, 2006).

Sitkoff, Harvard, The Struggle for Black Equality 1954-1980 (New York, Hill and Wang, 1981). 
Smith, A.C.H., with Elizabeth Immirzi \& Trevor Blackwell, Paper Voices: The Popular Press and Social Change 1935-1965 (London, Chatto \& Windus, 1975).

Troy, Gil, Morning in America: How Ronald Reagan Invented the 1980s (Princeton, Princeton University Press, 2005).

Washburn, Patrick, The African American Newspaper: Voice of Freedom (Evanston, Northwestern University Press, 2006).

\section{$\underline{\text { Dissertations and papers }}$}

Fluornoy, Craig, 'Reporting the Movement in Black and White: The Emmett Till Lynching and the Montgomery Bus Boycott', Dissertation, Louisiana State University and Agricultural and Mechanical College (August 2003).

Grimm, Joshua, 'Mirror, Mirror: Hegemonic Framing of Malclolm X and Martin Luther King, Jr. in the New York Times', Student paper, International Communication Association Annual Meeting in San Francisco (2007).

Settle, Stacey Eugene, 'News Narratives on Dr. Martin Luther King, Jr., and the Southern Christian Leadership Conference: The Atlanta Constitution and The Atlanta Daily World Consider Civil Rights in Alabama', A Dissertation Submitted to the Faculty of the Graduate School of Arts and Sciences of Howard University (May 1996).

\section{Journal Articles}

Berger, Jane, "“There is tragedy on both sides of the layoffs:" Privatization and the Urban Crisis in Baltimore', International Labor and Working-Class History, No. 71 (Spring 2007), pp. 29-49. 
Bostdorff, Denise, \& Goldzwig, Steven, 'History, Collective Memory, and the Appropriation of Martin Luther King, Jr.: Reagan's Rhetorical Legacy', Presidential Studies Quarterly, Vol. 35, No. 4 (December 2005), pp. 661-690.

Bowser, Benjamin, 'Race Relations in the 1980s: The Case of the United States', Journal of Black Studies, Vol 15, No. 3 (March 1985), pp. 307-324.

Carson, Clayborne, 'Martin Luther King, Jr.: Charismatic Leadership in a Mass Struggle', The Journal of American History, Vol. 74, No. 2 (September 1987), pp. 448-454.

Carson, 'The Unfinished Dialogue of Martin Luther King, Jr. and Malcolm X', OAH Magazine of History, Vol. 19, No. 1 (January 2005), pp. 22-26.

Entman, 'Framing: Toward Clarification of a Fractured Paradigm', Journal of Communication, Vol. 43, No. 4 (Autumn 1993), pp. 51-58.

Fairclough, Adam, 'Martin Luther King, Jr. and the War in Vietnam', Phylon, Vol. 45, No. 1 (1 ${ }^{\text {st }}$ Qtr., 1984), pp. 19-39.

Germany, Kent, 'The Politics of Poverty and History: Racial Inequality and the Long Prelude to Katrina', The Journal of American History, Vol. 94, No. 3 (December 2007), pp. 743-751.

Griffin, Charles J. G., 'Movement as Memory: Significant Form in Eyes on the Prize', Communication Studies, Vol. 54, No. 2 (Summer 2003), pp. 196-210.

Hall, Jacquelyn Dowd, 'The Long Civil Rights Movement and the Political Uses of the Past', The Journal of American History, Vol. 91, No. 4 (March 2005), pp. 1233-1263. 
Hall, Simon, 'The Response of the Moderate Wing of the Civil Rights Movement to the War in Vietnam', The Historical Journal, Vol. 46, No. 3 (September 2003), pp. 669-701.

Harding, Vincent Gordon, 'Beyond Amnesia: Martin Luther King, Jr., and the Future of America', The Journal of American History, Vol. 74, No. 2 (September 1987), pp. 468-476.

Jacobs, Ronald, 'Civil Society and Crisis: Culture, Discourse, and the Rodney King Beating', American Journal of Sociology, Vol. 101, No. 5 (March 1996), pp. 1238-1272.

Johnson, Davi, 'Martin Luther King Jr.'s 1963 Birmingham Campaign as Image Event', Rhetoric \& Public Affairs, Vol. 10, No. 1 (2007), pp. 1-26.

Lowenthal, David, 'History and Memory', The Public Historian, Vol. 19, No. 2 (Spring 1997), pp. 30-39.

O'Kelly, Charlotte, 'Black Newspapers and the Black Protest Movement, 19461972', Phylon, Vols 41, No. 4 (4 ${ }^{\text {th }}$ Quarter 1980), pp. 313-324.

O'Kelly, 'Black Newspapers and the Black Protest Movement: Their Historical Relationship, 1827-1945', Phylon, Vol. 43, No. 1 (1 ${ }^{\text {st }}$ Quarter 1982), pp. 1-14.

Paletz, David, \& Entman, Robert, 'Presidents, Power, and the Press', Presidential Studies Quarterly, Vol. 10, No. 3 (Summer 1980), pp. 416-426. 
Polletta, Francesca, 'Legacies and Liabilities of an Insurgent past: Remembering Martin Luther King, Jr., on the House and Senate Floor', Social Science History, Vol. 22, No. 4 (Winter 1998), pp. 479-512.

Sandage, Scott A., 'A Marble House Divided: The Lincoln Memorial, the Civil Rights Movement, and the Politics of Memory, 1939-1963', The Journal of American History, Vol. 80, Nol. 1 (June 1993), pp. 135-167.

Tuck, Stephen, "We Are Taking up Where the Movement of the 1960s Left off": The Proliferation and Power of African American Protest during the 1970s', Journal of Contermporary History, Vol. 43, No. 4 (October 2008), pp. 637-654. 


\section{Appendix}

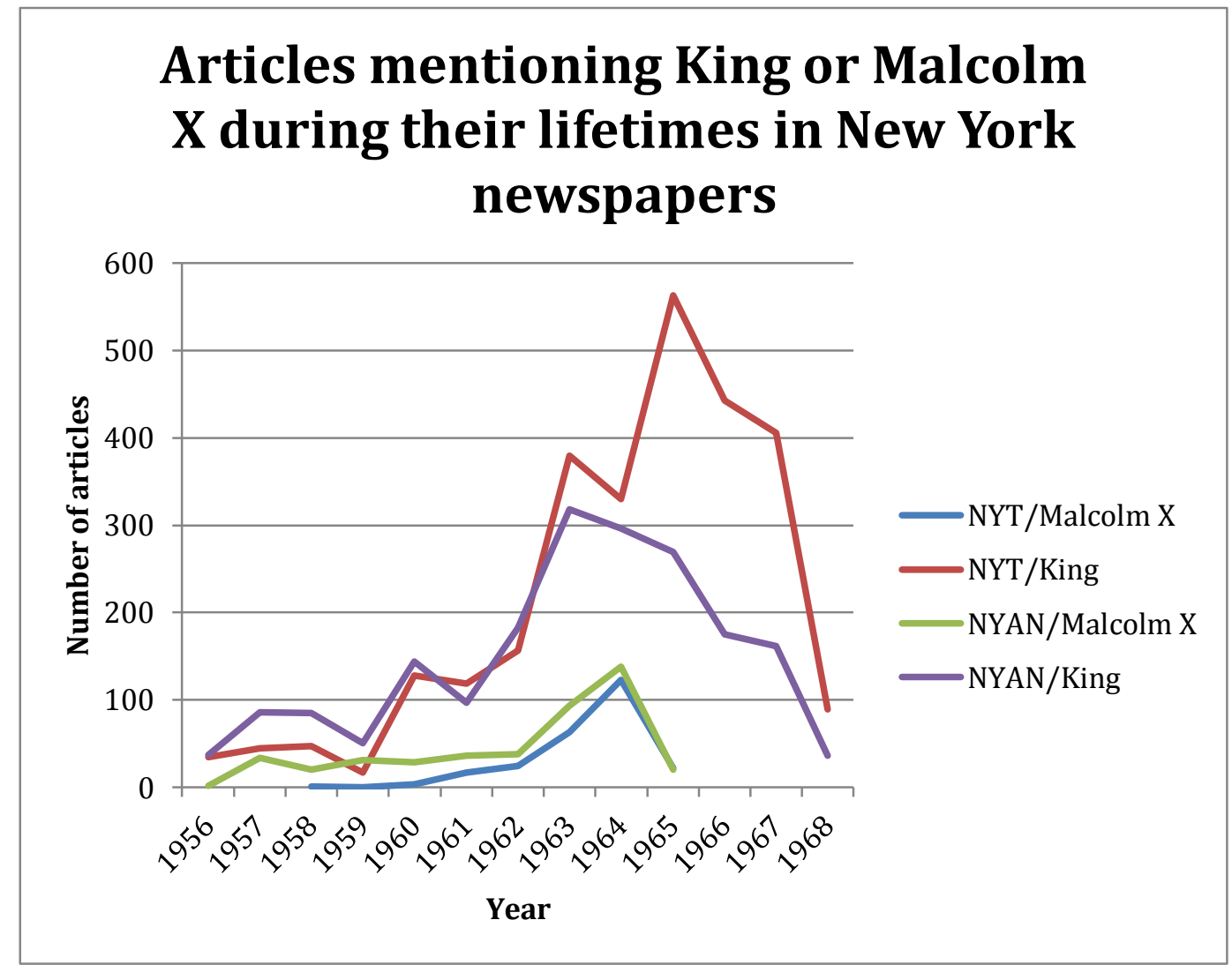

Figure 1.1

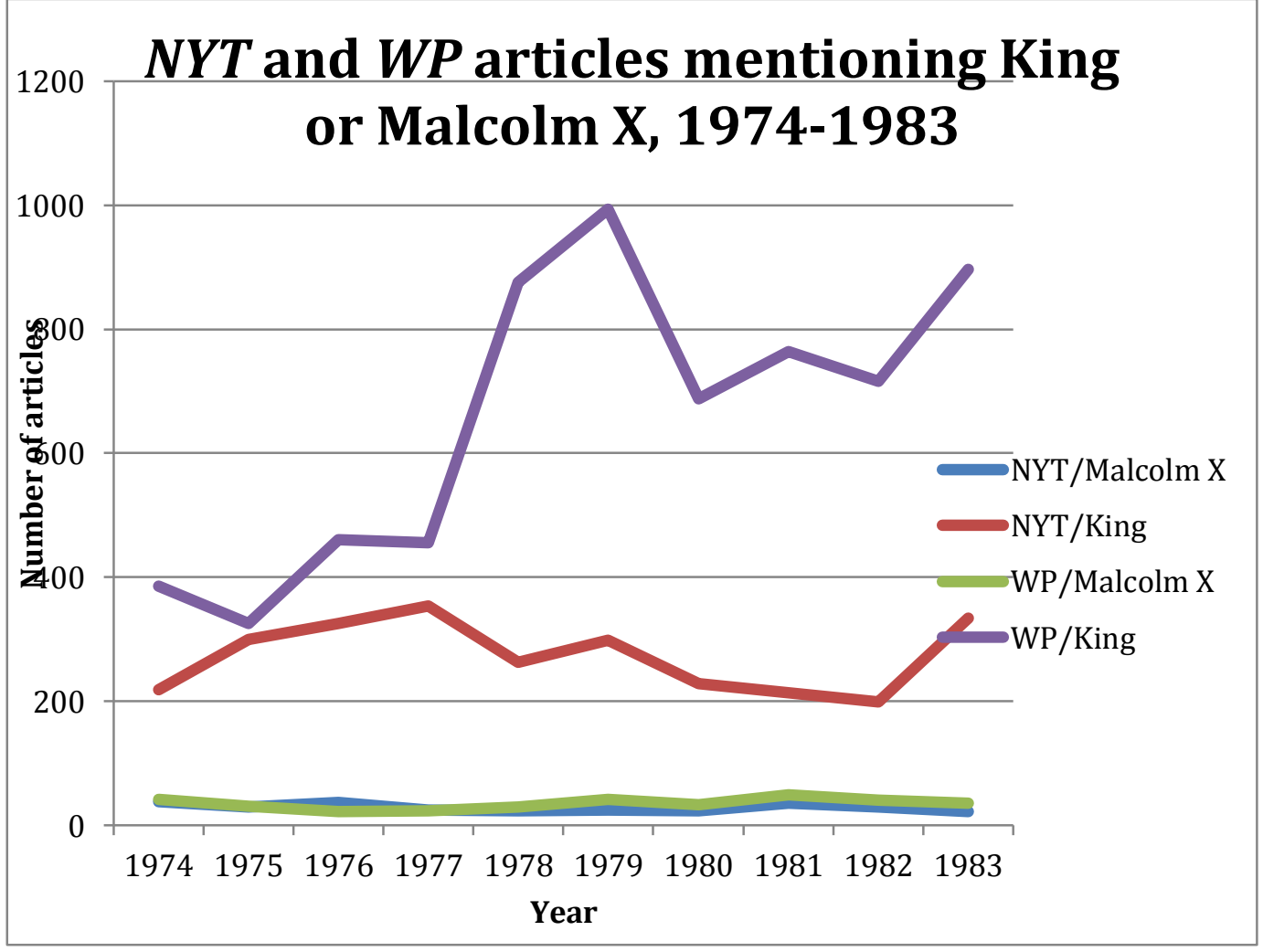

Figure 2.5 


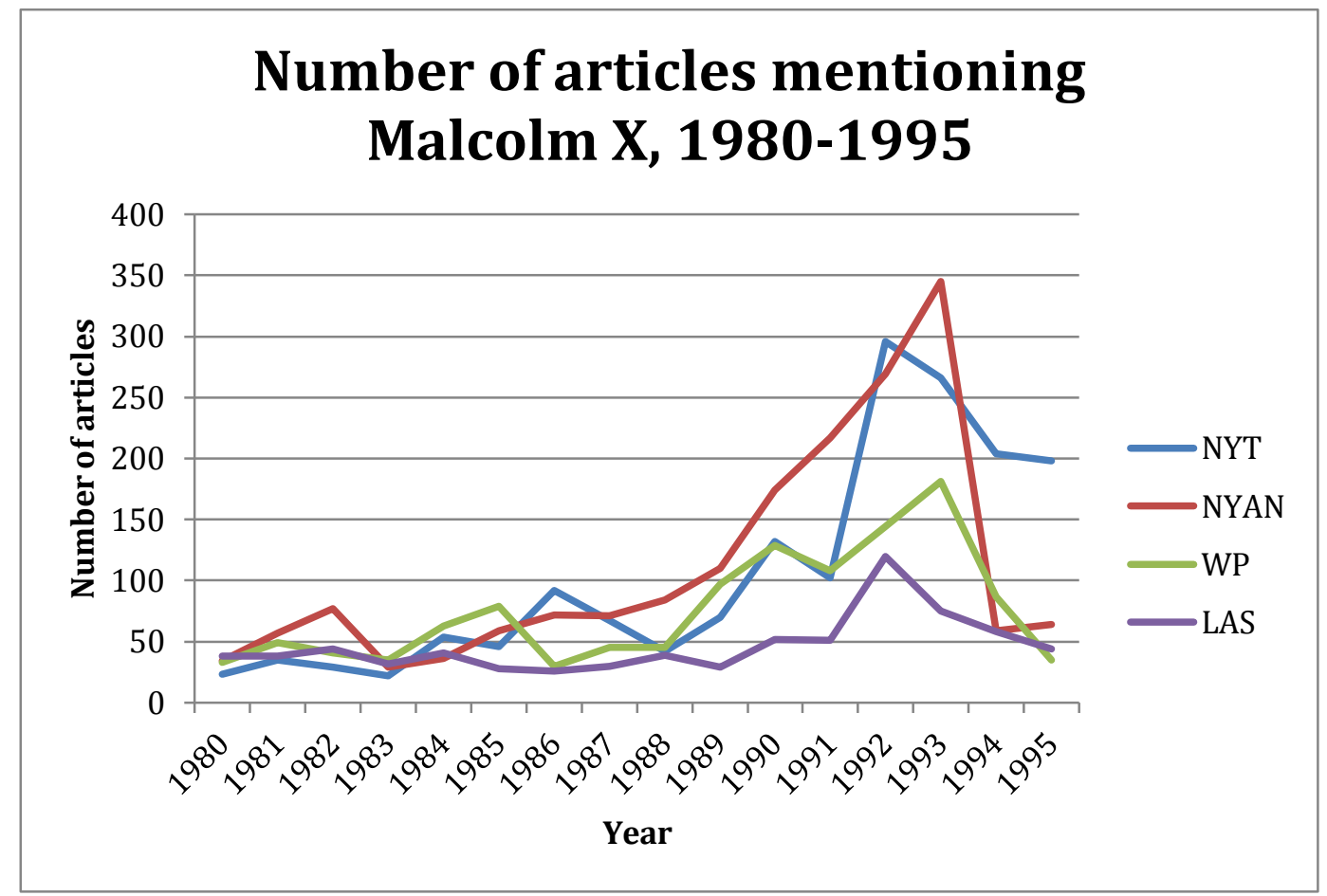

Figure 3.1 


\section{Other charts}

The $N Y T, N Y A N, W P$, and $L A S$, unlike the $A D W$ and $C D$, all have continuous runs from before the 1950 s to at least 1995 . The $L A T$ was not used because its results are skewed by multiple editions (San Diego County edition, Orange County edition, etc.) that are not easily isolated. 


\section{NYT articles mentioning King and} Malcolm X

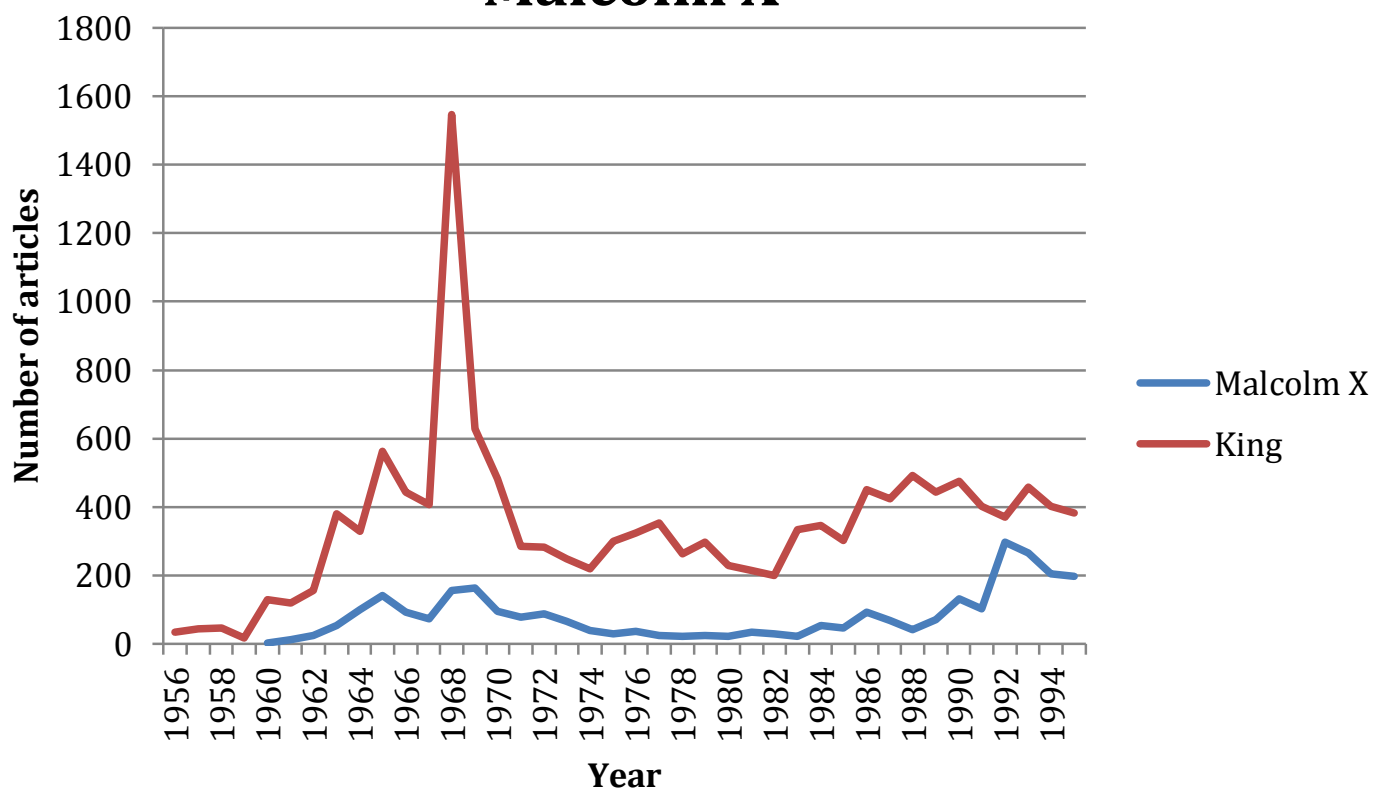

\section{NYAN articles mentioning King and Malcolm X}

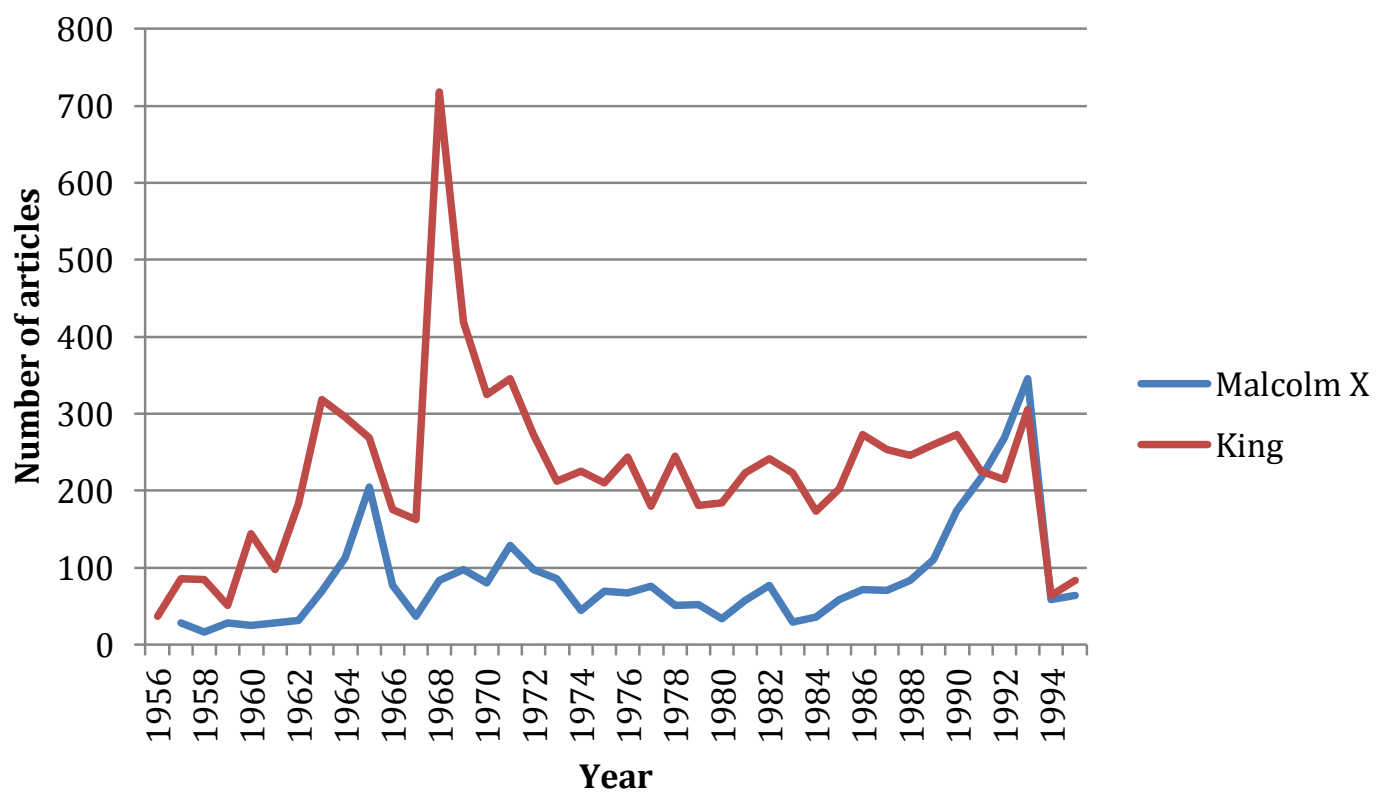



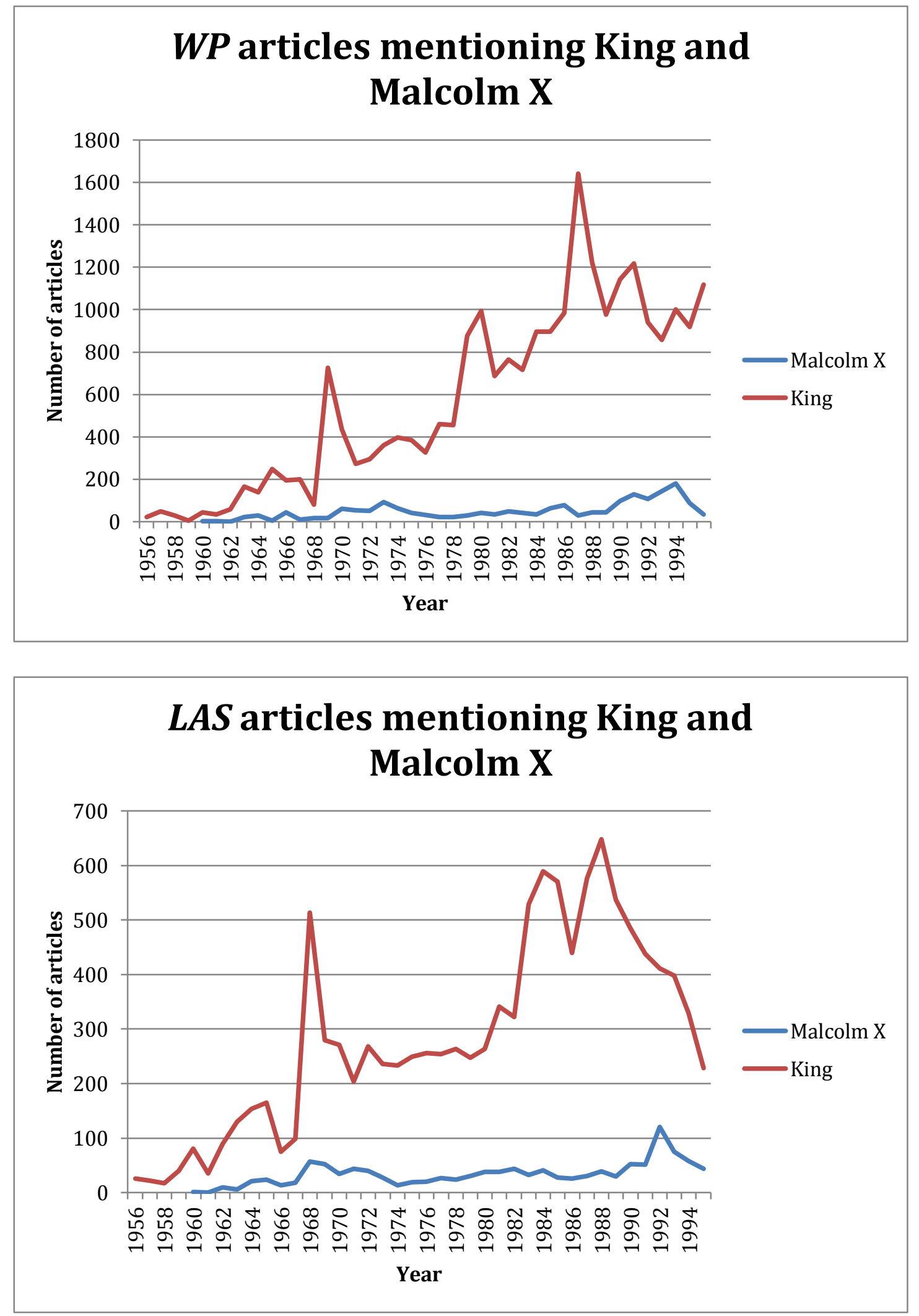